UNIVERSIDADE FEDERAL DE JUIZ DE FORA

FACULDADE DE COMUNICAÇÃO

PROGRAMA DE PÓS-GRADUAÇÃO EM COMUNICAÇÃO

BÁRBARA TORISU LEMOS

A REPRESENTAÇÃO DE GÊNERO NA TELENOVELA:

um estudo sobre Elisabeta e as personagens femininas em Orgulho e Paixão.

Juiz de Fora 
BÁRBARA TORISU LEMOS

A REPRESENTAÇÃO DE GÊNERO NA TELENOVELA:

um estudo sobre Elisabeta e as personagens femininas em Orgulho e Paixão.

Dissertação apresentada para o programa de PósGraduação em Comunicação, da Universidade Federal de Fora como requisito parcial à obtenção do grau de Mestre em Comunicação.

Área de concentração: Comunicação e Sociedade

Linha de pesquisa: Mídias e Processos Sociais

Orientadora: Profa. Dra. Iluska Maria da Silva Coutinho

Juiz de Fora 
Ficha catalográfica elaborada através do programa de geração automática da Biblioteca Universitária da UFJF, com os dados fornecidos pelo(a) autor(a)

Torisu Lemos, Bárbara.

A REPRESENTAÇÃO DE GÊNERO NA TELENOVELA : um estudo sobre Elisabeta e as personagens femininas em Orgulho e Paixão. /Bárbara Torisu Lemos. -- $2 \mathrm{O} 21$.

$143 p$.

Orientadora: Iluska Maria da Silva Coutinho

Dissertação (mestrado acadêmico) - Universidade Federal de Juiz de Fora, Faculdade de Comunicação Social. Programa de Pós-Graduação em Comunicação, $2 \mathrm{O} 21$.

1. Comunicação. 2. Telenovela. 3. Análise da Materialidade Audiovisual. 4. Orgulho e Paixão. 5. Estudo de gênero. I. Maria da Silva Coutinho, Iluska, orient II. Título. 


\section{A REPRESENTAÇÃO DE GÊNERO NA TELENOVELA: \\ um estudo sobre Elisabeta e as personagens femininas em Orgulho e Paixão.}

Dissertação apresentada para o programa de PósGraduação em Comunicação, da Universidade Federal de Fora como requisito parcial à obtenção do grau de Mestre em Comunicação.

Aprovada em 24 de fevereiro de 2021.

\section{BANCA EXAMINADOR}

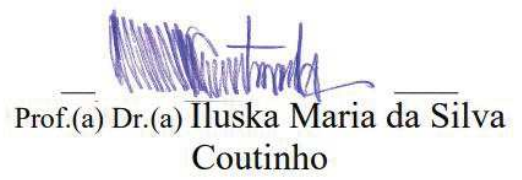

Orientadora

Universidade Federal de Juiz de Fora

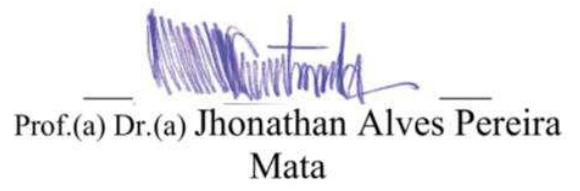

Universidade Federal de Juiz de Fora

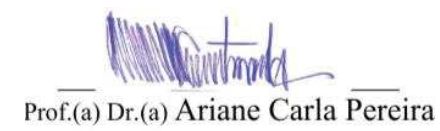

Universidade Estadual do Centro-Oeste 


\section{AGRADECIMENTOS}

Acredito que a nossa vida é feita de temporadas, que se iniciam e terminam trazendo pessoas e conhecimentos. E, agora, a temporada do mestrado na UFJF termina com muita felicidade! Sair da universidade na qual eu tinha feito a graduação me tirou da zona de conforto e ao mesmo tempo propôs um novo desafio para a minha trajetória acadêmica.

Por chegar até aqui, tenho que agradecer em primeiro lugar aos meus pais, Ramon e Claudia, meus irmãos, Marcela e Pedro, e ao tio Edmilson, por me terem me incentivado durante período do mestrado, e aos meus avós, Maria, Helena e Matias pelo apoio. Mudar-me para Juiz de Fora permitiu que eu conhecesse novas pessoas, novas leituras, uma nova universidade e tudo isso só foi possível graças ao corpo docente do PPCOM da UFJF que me selecionou e abriu as portas para que eu desenvolvesse a minha pesquisa.

Pelo percurso do desenvolvimento da dissertação, não posso deixar de agradecer aos professores da linha de pesquisa Mídias e Processos Sociais pelas discussões feitas em sala de aula. Agradeço especialmente aos professores Paulo Roberto e Cristina Brandão, pelas considerações e direcionamentos feitos na banca de qualificação. Agradeço, também, aos professores Ariane e Jhonatan, por aceitarem o convite de participar da última banca e pela oportunidade de aprender mais com as suas considerações. Em todo esse processo de formação, fica o meu eterno agradecimento à professora Iluska, por ter seguido comigo durante esse caminho do desenvolvimento da pesquisa e por ter me mostrado a importância de estudar o audiovisual. Também tenho que agradecer a todos os membros do NJA por terem formado essa rede afeto dentro e fora da universidade e por sempre trazerem discussões interessantes. Eu aprendi muito com vocês!

Não posso me esquecer de agradecer aos colegas de turma das linhas de pesquisa de Mídias e Processos sociais e Competência Midiática, Estética e Temporalidade. Ter vocês no meu dia a dia fizeram com que essa passagem pelo mestrado fosse muito mais leve. E aos amigos Ana, Cícero, Clarissa, Guilherme, Isadora, Júlia, Luana, Matheus, Thiago, Isabela e Samara, por terem me acompanhado no desenvolvimento do mestrado. O presente trabalho foi realizado com apoio da Coordenação de Aperfeiçoamento de Pessoal de Nível Superior - Brasil (CAPES) - Código de Financiamento 001

Todos vocês foram muito importantes para alcançar esse objetivo! 


\section{RESUMO}

Este trabalho analisa a construção da identidade da mulher e a representação de gênero na telenovela Orgulho e Paixão, que foi exibida pela Rede Globo em 2018, no horário das 18h. Por meio do entendimento dos valores sociais atribuído às mulheres do século XX, buscamos compreender como as personagens da trama atuavam para tensionar com esses valores tradicionais que destinavam as mulheres ao espaço do lar e, principalmente, ao casamento e quais atitudes e pensamentos seriam abordados para a criação da identidade da mulher moderna. A metodologia escolhida foi a Análise da Materialidade Audiovisual, que é desenvolvida pelo Núcleo de Jornalismo e Audiovisual (UFJF-CNPq), pela qual buscamos entender a unidade entre texto + som + imagem + texto + edição. A partir desta análise quali-quantitativa, verificamos que as personagens e as situações de concordância e de discordância nos discursos sobre os valores da mulher contribuíram para colocar em evidência o principal debate, que era a posição da mulher dentro da sociedade. Identificamos que, como Orgulho e Paixão é uma telenovela de época, esses valores tradicionais são muito fortes na sociedade e os tensionamento propostos pelas personagens femininas ficaram mais evidentes.

Palavras-chave: Telenovela; Orgulho e Paixão; Ficção seriada; Feminismo; Representação de Gênero. 


\begin{abstract}
This work analyzes the construction of women's identity and the gender representation in the telenovela Pride and Passion, which faith shown by Rede Globo, in 2018, at 18h. Through understanding about the values of women of the 20th century, we seek to understand how characters in the plot acted to tension these traditional values that destined women to the home space and, mainly, to marriage and what attitudes and thoughts thought for the creation of the identity of modern women. The methodology chosen was the Analysis of Audiovisual Materiality, which is developed by the Journalism and Audiovisual Center (UFJF-CNPq) in which we seek to hear unity between text + sound + image + text + edition. From this qualitative and quantitative analysis, we found that the characters and the hypotheses of agreement of disagreement in our discourses on the values of women contributed to highlight the main debate that will be the position of women in society. We identified that as Pride and Passion is a telenovela of the time, these traditional values are very strong in society and the tensioning proposed by female characters were easier to notice.
\end{abstract}

Keywords: Telenovela; Pride and Passion; Serial fiction; Feminism; Gender Representation 


\section{LISTA DE FIGURAS}

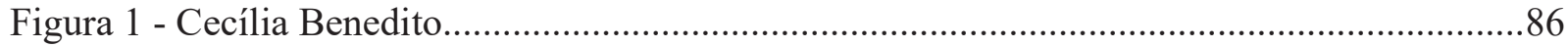

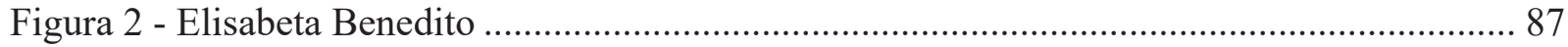

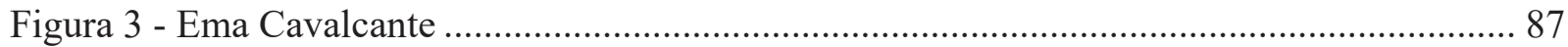

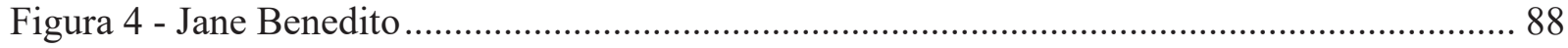

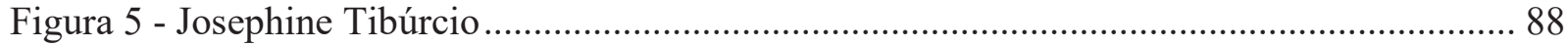

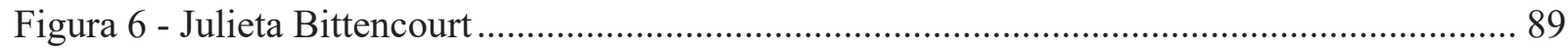

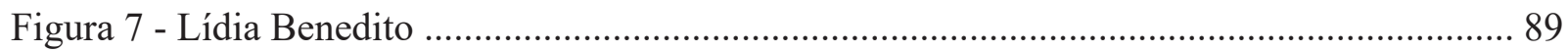

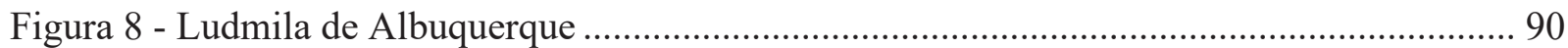

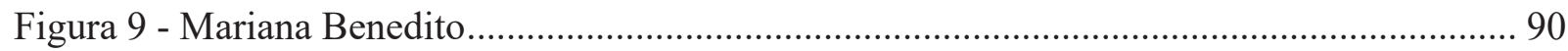

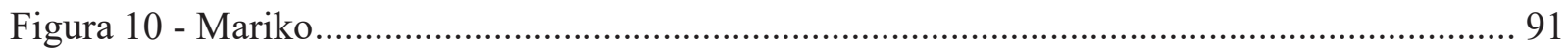

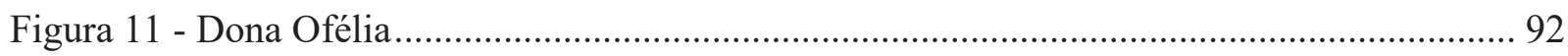

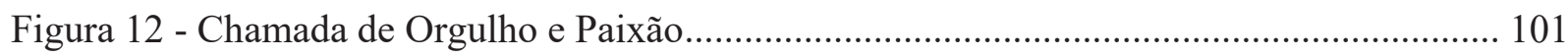

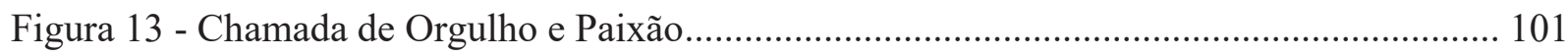

Figura 14 - Elisabeta na chamada de Orgulho e Paixão .............................................................. 102

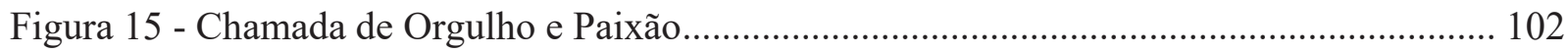

Figura 16 - Aviso de que violência contra a mulher é filme no capítulo 127, exibido no dia 14 de

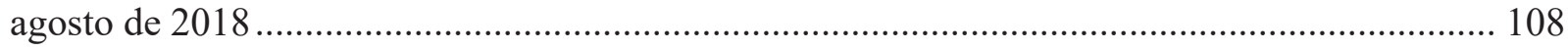

Figura 17 - Representação das casas do século XX ………….................................................... 129 


\section{LISTA DE GRÁFICOS}

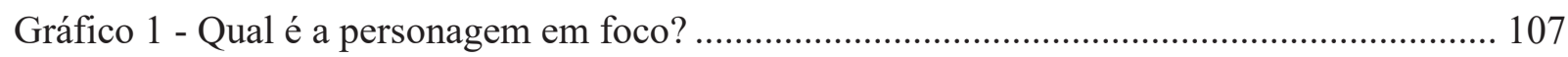

Gráfico 2 - Há mulheres em cena além da personagem? ......................................................... 112

Gráfico 3 - Qual a promessa que a narrativa da cena propõe? .................................................. 113

Gráfico 4 - A discussão é um conflito ou tem concordância? ..................................................... 116

Gráfico 5 - Quais papéis são identificados para as mulheres? ................................................... 119

Gráfico 6 - Como essa temática foi abordada dentro da narrativa?........................................... 121

Gráfico 7 - Com quem as personagens estão interagindo no momento da reflexão do papel da

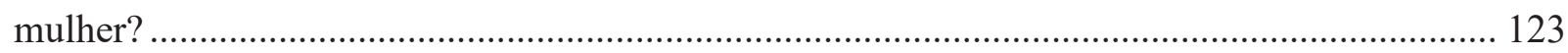

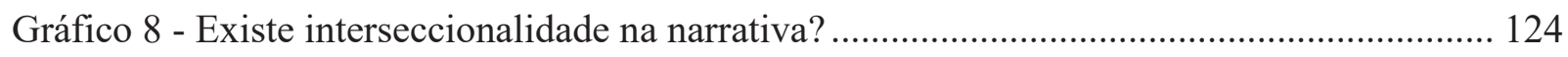

Gráfico 9 - Há o entendimento com relação ao tensionamento da tradição? ............................... 127 


\section{LISTA DE QUADROS}

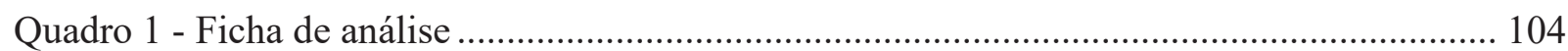




\section{LISTA DE SIGLAS E ABREVIAÇÕES}

FBPF - Federação Brasileira para o Progresso Feminino

IBGE - Instituto Brasileiro de Geografia e Estatística

ONGs - Organizações Não Governamentais

ONU - Organização das Nações Unidas

Pnad - Pesquisa Nacional por Amostra de Domicílios Contínua

Secadi - Secretaria de Educação Continuada, Alfabetização, Diversidade e Inclusão

SPM - Secretaria de Políticas para as Mulheres 


\section{SUMÁRIO}

1 INTRODUÇÃO

2 A CONSTRUÇÃO DA IDENTIDADE DA MULHER............................................................16

2.1 A CONSTRUÇÃO DA IDENTIDADE FEMININA E AS SUAS REPRESENTAÇÕES .... 16

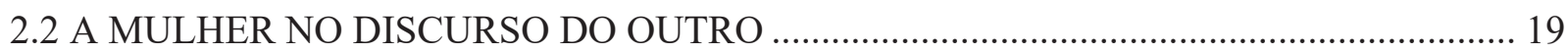

2.3 A ORIGEM DO ESTUDO SOBRE AS MULHERES ........................................................... 23

3 FEMINISMOS PLURAIS.............................................................................................................31

3.1 AS ONDAS FEMINISTAS NA EUROPA E NOS ESTADOS UNIDOS ………………….... 31

3.2 A CONTEXTUALIZAÇÃO DO FEMINISMO NO BRASIL ……………………………........ 35

3.3 AS MULHERES NO BRASIL REPÚBLICA: COSTUMES E VALORES DA SOCIEDADE 38

3.4 O MARCO PARA A MULHER BRASILEIRA: A TOMADA DA CONSCIÊNCIA ........... 41

3.5 A MULHER NO SÉCULO XXI: O BRASIL CONTEMPORÂNEO ……………………….... 54

4 AS TELENOVELAS E A REPRESENTAÇÃO SOCIAL.........................................................58

4.1 ANALISANDO A HISTÓRIA DA TELENOVELA NO BRASIL …………………….......59

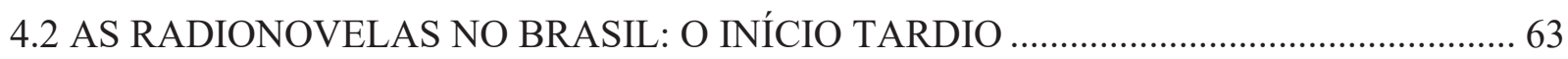

4.3 DA RÁDIO PARA A TELEVISÃO: O MELODRAMA NA TV BRASILEIRA ………….... 63

4.4 A TELENOVELA NA CASA DOS BRASILEIROS: A TELENOVELA DIÁRIA................ 66

4.5 AS TELENOVELAS COMO PRODUÇÃO DA CULTURA MIDIÁTICA............................. 72

4.6 CRIADA PARA ATINGIR O PÚBLICO FEMININO ……………………………….... 78

4.7 AS TELENOVELAS DAS SEIS ............................................................................... 82

5 UMA NOVELA DE ÉPOCA CONTEMPORÂNEA: O FEMINISMO EM UMA NARRATIVA FICCIONAL DA DÉCADA DE 1920....................................................................84

5.1 AS PERSONAGENS FEMININAS EM ORGULHO E PAIXÃO ………………………….... 86

5.2 ELIZABETA: UMA REPRESENTAÇÃO DE UM TIPO DE IDENTIDADE FEMININA. 92 
6 ANALISANDO A MATERIALIDADE AUDIOVISUAL DE ORGULHO E PAIXÃO......96

6.1 COMO ESTUDAR PROGRAMAS DE TELEVISÃO CONTEMPLANDO TODAS AS

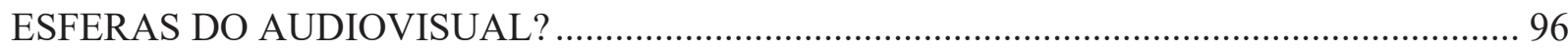

6.2 A ANÁLISE DA MATERIALIDADE AUDIOVISUAL COMO UMA METODOLOGIA

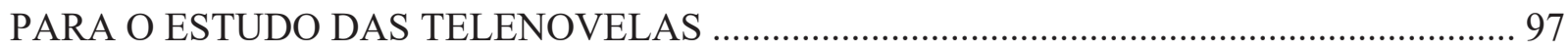

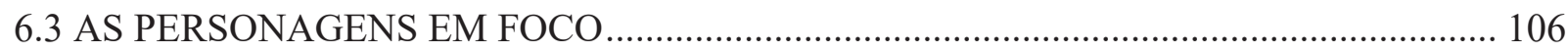

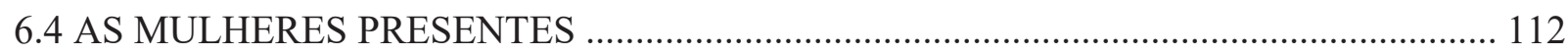

6.5 AS PROMESSAS DA NARRATIVA DE ORGULHO E PAIXÃO …................................ 113

6.6 ESSAS DISCUSSÕES SÃO DE CONFLITO OU CONCORDÂNCIA? ............................ 116

6.7 OS PAPÉIS MAIS RECORRENTES DAS MULHERES EM ORGULHO E PAIX $\tilde{A O}$...... 118

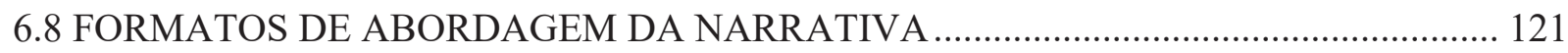

6.9 QUEM ESTÁ PRESENTE COM AS PERSONAGENS NO MOMENTO DAS

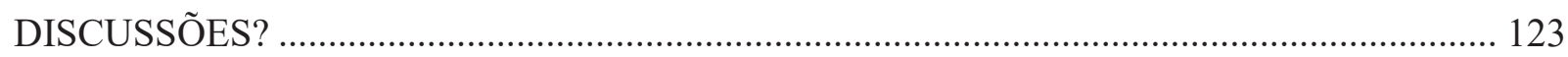

6.10 AS NARRATIVAS INTERSECCIONAIS DENTRO DE ORGULHO E PAIXÃO ........... 124

6.11 O TENSIONAMENTO DAS CONVENÇÕES E O ENTENDIMENTO DAS

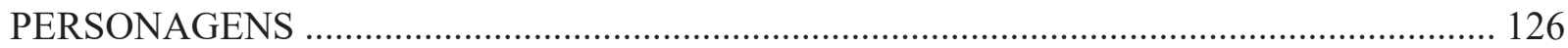

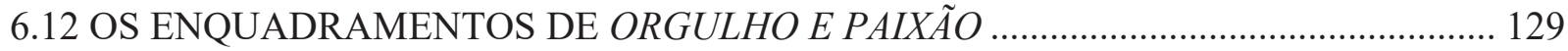

6.13 OS SONS PRESENTES EM ORGULHO E PAIXÃO …................................................ 130

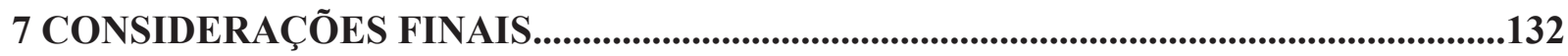

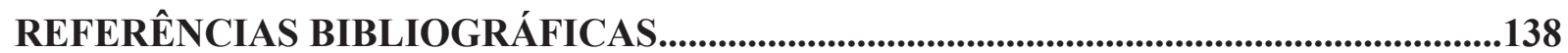

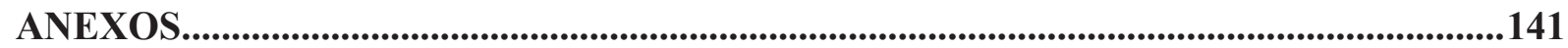




\section{INTRODUÇÃO}

As telenovelas são programas televisivos que conseguem criar o sentimento de pertencimento para os telespectadores. Para Maria Immacolata Vassallo de Lopes (2008), esse programa tem a capacidade de criar esse sentimento porque se conecta com as dimensões que são temporais, com o passado, presente e futuro, o que acontece pela construção e antecipação sobre uma série de eventos ou campos próprios. E as telenovelas são fortes elementos na construção do sentido de identidade nacional, pois é um espaço para a representação de diferentes grupos sociais e para ter acesso a essas representações.

O pesquisador Jésus Martín-Barbero (1997) define os melodramas como sendo o gênero mais expressivo na América Latina. Esse programa trata de como as relações trocadas nas praças e nos mercados e mistura as estruturas sociais, os sentimentos, os sonhos e o que as pessoas desejam ser. Para Douglas Kellner (2001), os meios de comunicação como rádio, televisão e cinema são formas de oferecer modelos do que é ser homem e mulher, o que é ser bem sucedido ou não, poderoso ou impotente.

A partir desse entendimento do que é telenovela e das possibilidades de representação que ela nos propõe, percebemos que esses programas se tornam objetos de pesquisa para pesquisadores de comunicação. Essa necessidade se mostra presente visto que a televisão se tornou parte do cotidiano das pessoas e que, com base na Pesquisa Nacional por Amostra de Domicílios Contínua (Pnad) feita pelo Instituto Brasileiro de Geografia e Estatística (IBGE) de $2018^{1}$, constatou-se que dos 71.738 mil domicílios permanentes do Brasil, em 96,4\% deles haviam televisão em casa. Com relação à internet, em 2017,79,1\% das residências utilizavam a rede de computadores.

Ao observar a diversidade de possibilidades que a telenovela nos traz, percebemos que esse é um canal que pode ser usado para entender como é feita a representação de gênero para a população brasileira. Segundo Heloisa Buarque de Almeida (2002), os meios de comunicação funcionam como intermediários para as mudanças de padrão de consumo e no ambiente que abrange as representações sociais sobre o que é amor, casamento e relações familiares.

Usar os meios de comunicação como uma forma de se comunicar com as mulheres e trazer discussões sobre as condições em que elas são colocadas é algo que existe desde que as mulheres

\footnotetext{
${ }^{1}$ Essa pesquisa foi desenvolvida pelo Instituto Brasileiro de Geografia e Estatística (IBGE) em 2018. Disponível em: https://biblioteca.ibge.gov.br/visualizacao/livros/liv101705_informativo.pdf. Acesso em: 23 jan. 2021.
} 
começaram a atuar nos meios de comunicação. Céli Regina Jardim Pinto (2003) recorre a Buitoni (1981) para afirmar que as primeiras publicações feitas por mulheres se iniciaram no início do século XIX e traziam questões quase que exclusivamente sobre moda, mas esse quadro se alterou e temas como política, literatura e cultura começaram a aparecer. Apesar de ser um contexto que trata sobre o movimento de emancipação das mulheres, os valores tradicionais ainda recaem sobre elas e essas normas orientam a forma como as mulheres viverão.

Ao entender as telenovelas brasileiras como marcos identitários e de representação do outro, estas qualificam-se como recorte em pesquisas acerca da sociedade brasileira, em sua relação com a mídia e a partir desses diálogos. Escolhemos como objeto de estudo a telenovela Orgulho e Paixão, veiculada entre os meses de março e setembro de 2018, que foi livremente inspirada nos romances da Jane Austen. A narrativa da novela das seis da Rede Globo de Televisão se passa no início do século XX, no fíctício do Vale do Café, que fica localizado no interior de São Paulo.

Escrita e dirigida por Marcos Bernstein e com a direção artística de Fred Mayrink, a telenovela apresenta questões relacionadas aos costumes da época, às questões sociais, à luta pela individualidade, a aventuras amorosas e à disputa entre heróis e vilões ${ }^{2}$. A trama central de Orgulho e Paixão foi adaptada para o contexto e história brasileira. Elisabeta, interpretada por Nathália Dill, é a filha mais velha da Ofélia, interpretada pela Vera Holtz, e do Felisberto Benedito, interpretado por Tato Gabus Mendes, e é apresentada como uma mulher à frente do seu tempo, que busca direitos igualitários entre homens e mulheres no século XX. Como na história de Orgulho e Preconceito, de Jane Austen, a família Benedito é composta de cinco filhas, Elisabeta, Jane (Pamela Tomé), Mariana (Chandelly Braz), Cecília (Anaju Dorigon) e Lídia (Bruna Griphão). A intenção da Dona Ofélia é fazer com que todas se casem com bons partidos, conforme o que a sociedade esperava para as moças da época. Nilson $\mathrm{Xavier}^{3}$ (S/D) Considera que Ofélia Benedito faz qualquer malabarismo para conquistar um bom partido para as suas cinco filhas, mas Elisabeta não se insere nos moldes impostos por essa sociedade. A personagem principal busca a liberdade e tem uma ousadia natural, que pode afastar ou encantar os pretendentes (XAVIER, S/D).

\footnotetext{
2 Todas as informações mencionadas nesse tópico sobre a telenovela foram encontradas no site do Gshow. Disponível em: https://gshow.globo.com/novelas/orgulho-e-paixao/noticia/orgulho-e-paixao-conheca-a-historia-da-nova-noveladas-6.ghtml>. Acesso em: 9 jul. 2020.

${ }^{3}$ Nilson Xavier é um estudioso e fã de telenovela. Desde o ano 2000, ele abastece um site onde faz registros de acordo com as pesquisas que faz sobre as tramas. Todas as informações apresentadas pelo Xavier estão disponíveis em http://teledramaturgia.com.br/orgulho-e-paixao/. Acesso em: 8 jul. 2020.
} 
A partir dessa pesquisa, nosso objetivo é identificar: como a telenovela Orgulho e Paixão, por meio da personagem Elisabeta, promove o questionamento sobre os valores determinados para as mulheres no século XX, buscando entender o paralelo que pode ser feito com a sociedade contemporânea. E a nossa hipótese é de que a telenovela constrói a imagem da Elisabeta como uma mulher à frente do seu tempo ao abordar os debates promovidos nos dias de hoje pelo movimento feminista. Elisabeta se torna a personificação dessa busca e, para isso, ela deixa o lugar que era destinado às mulheres e luta para ter as mesmas condições dos homens.

Para a realização desta pesquisa, recorremos ao método da Análise da Materialidade Audiovisual (COUTINHO, 2018), por possibilitar a avaliação a unidade de texto + som + imagem + tempo + edição, contemplando todos os códigos, elementos e símbolos do audiovisual. Essa metodologia é dividida em cinco etapas, sendo que a primeira é a identificação do objeto audiovisual e das suas propostas; a segunda é a elaboração da ficha de análise; a terceira é o préteste do instrumento; a quarta é a pesquisa documental ou definição e obtenção da amostra a ser estudada; e a quinta é a construção de parâmetros de interpretação dos dados e, em alguns casos, de um material de codificação.

A partir do conhecimento dos autores e da escolha do objeto de pesquisa, iniciamos a coleta de dados das pesquisas e selecionamos os dados das telenovelas que iriam compor o corpo analítico. Nesse caso, identificamos os capítulos e as cenas e fizemos uma descrição delas, que contempla o assunto da discussão, a personagem que é o foco da discussão, os enquadramentos e a sinopse dos capítulos (Anexo I). Ao final da coleta de dados, chegamos ao total de 263 cenas a serem analisadas, que fazem parte dos 162 capítulos observados.

Para o estudo da telenovela, fizemos uma ficha de análise com 13 questões para realizar uma análise quali-quantitativa das cenas de Orgulho e Paixão. Essa ficha foi criada com base nas referências sobre as autoras que estudam a posição das mulheres no século XX e XXI e dos pesquisadores da telenovela. A partir dessa ficha de análise, conseguimos criar nove gráficos de onde tiramos dados sobre os principais papéis, meios de interação e ciclo sociais em que essas personagens buscam romper ou reforçar os ideais tradicionais que foram colocadas e reafirmadas ao longo da narrativa.

Ao final da pesquisa, conseguimos identificar que, de todas as personagens presentes na telenovela, Elisabeta é quem tem mais destaque na narrativa. Contudo, apesar de ela concentrar a maior parte das participações e inserções, na narrativa, ela conta com o apoio de outras personagens 
como Ema, Julieta, Mariana, Mariko e Ofélia, que auxiliam a evidenciar um discurso feminista sobre as mulheres em uma novela de época consumida no tempo presente. Essas personagens ajudam nessa parte porque, quando elas concordam ou discordam dessas atitudes ou ações que rompem com o tradicionalismo, elas deixam essa discussão mais evidente. Isso nos mostra que o fato de Orgulho e Paixão ser uma telenovela de época que representa o século XX, as ações assumidas pelas personagens ficam ainda mais evidentes devido aos valores daquele período serem mais fortes. A mulher trabalhadora foi a posição feminina identificada na narrativa, e a esposa foi a segunda ocupação mais apresentada. E percebemos que isso expõe como esse embate entre o tradicional e o moderno. Assim, a esposa representa o casamento, e o trabalho, a independência ou emancipação feminina.

Esta dissertação está organizada em sete capítulos, nos quais buscamos construir uma narrativa para o entendimento de quem são essas mulheres, de como as telenovelas se tornam possíveis objetos de pesquisa, de Orgulho e Paixão como objeto de pesquisa, da Análise da Materialidade Audiovisual e sua aplicação na telenovela e as considerações finais.

No primeiro capítulo, introduzimos esta pesquisa e apresentamos um panorama do estudo e dos principais pontos de discussão. No capítulo 2, fizemos uma apresentação da construção da identidade feminina, de como elas eram representadas no discurso e como se iniciou o estudo sobre as mulheres. No capítulo 3, apresentamos a história dos movimentos femininos no Brasil e no mundo e investigamos quais valores e posicionamentos eram colocados para as mulheres do século XX para entender o que Elisabeta precisaria seguir ou romper para fazermos essa discussão. No capítulo 4, abordamos a história das telenovelas no Brasil e no continente Americano e como a sua participação diária na vida dos brasileiros permite que esse objeto seja usado para entender a nossa sociedade. No capítulo 5, apresentamos a história de Orgulho e Paixão e as principais personagens femininas. No capítulo 6, tratamos da metodologia científica e da análise das cenas. E, no sétimo capítulo, fizemos as considerações finais sobre esta pesquisa. 


\section{A CONSTRUÇÃO DA IDENTIDADE DA MULHER}

A mulher como sujeito das suas próprias vidas é um tema que vem sendo discutido ao longo dos últimos anos, e os desafios de entender esse indivíduo enquanto sujeito social perpassam pelas discussões de que existe o binarismo, a separação do gênero feminino e masculino, conforme aponta Judith Butler (2018). Os registros históricos colocam o feminino no lugar do outro, de forma que as definições sobre o que é ser mulher são feitas com base no discurso e no significado que os homens atribuem a elas, como Maria Rita Kehl (2016) nos apresenta.

Muitas das percepções que temos hoje em dia sobre a representação da mulher são oriundas de uma construção de identidade que vem sendo edificada há alguns anos. Entender a origem dessas criações nos permite refletir sobre o lugar da mulher nos dias de hoje. Neste capítulo, buscamos analisar como essa identidade feminina foi construída.

\subsection{A CONSTRUÇÃO DA IDENTIDADE FEMININA E AS SUAS REPRESENTAÇÕES}

O entendimento do que é ser mulher na sociedade perpassa uma lógica que é marcada pela influência do que já tinha sido construído ao longo da história. Judith Butler (2018, p. 19) comenta que "porém, em virtude de a elas estarem condicionadas, os sujeitos regulados por tais estruturas são formados, definidos e reproduzidos de acordo com a exigência dela". Essa estrutura política mencionada pela autora cria o entendimento do que é o sujeito do feminismo com base nos traços estabelecidos pela determinação de gênero.

Em outras palavras, a construção política do sujeito procede veiculada a certos objetivos de legitimação e de exclusão, e essas operações políticas são efetivamente ocultas e naturalizadas por uma análise política que toma as estruturas jurídicas como seu fundamento (BUTLER, 2018, p. 19).

Percebe-se que esse entendimento é legitimado com base na forma como as estruturas sociais e políticas o definem. Nessa perspectiva, Maria Rita Kehl (2016) nos lembra que a feminilidade foi construída pensando em uma maneira ideal de como as mulheres deveriam ser e agir a partir das concepções formadas pelo imaginário masculino. Para entender essa posição feminina, precisamos compreender a lógica que estrutura essa organização social, assim, Butler (2018, p. 20) argumenta que "a crítica feminista também deve compreender como a categoria das 
'mulheres', o sujeito do feminismo, é produzida e reprimida pelas mesmas estruturas de poder por intermédio das quais se busca a emancipação".

Para que as mulheres tenham a sua independência, elas ainda necessitam buscar a sua legitimação dentro do sistema no qual elas estão inseridas, e Rachel Soihet (2004, p. 308) comenta que "a liberdade sexual das mulheres populares parece confirmar a ideia de que o controle intenso da sexualidade feminina estava vinculado ao regime de propriedade privada".

Essa separação e distinção social entre os papeis atribuídos aos homens e as mulheres tem como tese estar baseada na natureza e na diferenciação corporal, que se torna o principal argumento para que haja a divisão. No entanto, essa separação biológica entre os gêneros não se prende apenas a isto, pois existe uma construção cultural que promove a difusão deste entendimento sobre os indivíduos.

\begin{abstract}
Em algumas explicações, a ideia de que gênero é construído sugere certo determinismo de significados do gênero, inscritos em corpos anatomicamente diferenciados, sendo esses corpos compreendidos como recipientes passivos de uma lei inexorável. Quando a "cultura" relevante que "constrói" o gênero é compreendida nos termos dessa lei ou conjunto de leis, tem-se a impressão de que o "gênero" é tão determinado e tão fixo quanto na formulação de que a biologia é o destino. Nesse caso, não a biologia, mas a cultura se torna o destino (BUTLER, 2018, p. 28-29).
\end{abstract}

Essa fixação no entendimento do que é o gênero é baseada em normas sociais que nos fazem entender e conhecer quais características determinam o que é ser homem e o que é ser mulher. O corpo se torna a tela no qual as definições são colocadas, e a interpretação desses corpos é feita pelo o que se tem de entendimento da construção do gênero. Tais determinações são formuladas com base nos momentos históricos pelo qual aquela sociedade está passando.

O gênero feminino é constituído a partir do entendimento do masculino como ideal normativo e, assim, o feminino se constitui enquanto o "outro" desta relação. Butler (2018) aborda que não se pode pensar na relação entre feminino e masculino em uma economia significante em que o masculino é o significante e, ao mesmo tempo, o significado, pois essas relações sempre terão como base o masculino para pensar na forma do gênero feminino. A autora ainda completa que, "paradoxalmente, Beauvoir pré-figurou essa impossibilidade em O segundo sexo, ao argumentar que os homens não podiam resolver a questão das mulheres, nesse caso, estariam agindo como juízes e partes interessadas" (BUTLER, 2018, p. 33). 
Após refletir sobre o significado de diferença, a autora Lilia Schwarcz (2019) comenta que todas as sociedades criam os seus marcadores sociais das diferenças e que é a partir deles que os estereótipos sociais são criados. E é com base nessas classificações que podemos entender a origem dos preconceitos, discriminações e violências.

As diferenças não deveriam ser pontuadas como algo negativo. Schwarcz (2019) comenta que são elas que podem promover um conhecimento rico e plural para quem tem contato com elas. Porém, essas características são usadas como marcadores ao realizarem a separação e contribuem para que alguns grupos sejam isolados em detrimento de outros, privilegiados. A autora traz em sua obra a definição de marcadores sociais das diferenças feita pelo Núcleo de Estudos sobre Marcadores Sociais da Diferenças, da Universidade de São Paulo (USP), que são:

[...] categorias classificatórias compreendidas como construções sociais, locais, históricas e culturais, que pertencem à ordem das representações sociais - a exemplo das fantasias, dos mitos, das ideologias que criamos -, quanto exercem uma influência real no mundo, por meio da produção e reprodução de identidades coletivas e hierarquias sociais (SCHWARCZ, 2019, p. 175).

É possível perceber que esses marcadores são oriundos de uma construção social feita para algum grupo específico, assim, temos como marcadores mais conhecidos a raça, o gênero, o local de origem e o sexo. Essas classificações não acontecem somente de maneira separada, elas podem se manifestar em conjunto para identificar um sujeito. São esses marcadores que legitimam a posição do homem como superior à mulher, de forma que

[...] as mulheres deveriam atuar como 'princesas', obedecendo e se subordinando aos maridos, enquanto os homens são eternos 'príncipes', cientes de seu domínio e autoridade (e, mais uma vez, não há apenas coincidência com os nossos tempos atuais) (SCHWARCZ, 2019, p. 197).

Para a autora, com essa perspectiva, os comportamentos das mulheres devem ser sempre em favor do desejo dos homens. São eles, que com a autoridade legitimada pelo gênero, ditam o que elas devem fazer ou não. Quando as mulheres começam a querer impor a sua independência e autonomia, os homens começam a reagir de forma negativa a essas atitudes. Nesse caso, elas podem ser configuradas como forma de violência contra esses sujeitos. A autora apresenta isso como misoginia, que é o ódio, o preconceito e o desprezo contra as mulheres. 
Desde o final dos anos 1970, as mulheres definitivamente deixaram o lugar social que lhes era predeterminado em nosso país - o da passividade ou do vitimismo e, a partir de movimentos organizados, passaram a reivindicar direitos e oportunidades iguais no trabalho, no lazer, dentro de casa e no espaço público (SCHWARCZ, 2019, p. 1987).

Mesmo com a busca pela independência promovida por essas mulheres, ainda é possível perceber que elas não estão sendo representadas dentro do cenário político nacional. Mas, ao mesmo tempo, também notamos a emergência de outras frentes que lutam pelo reconhecimento no século XXI, como o feminismo negro, que "tem chamado muita atenção para a peculiaridade da situação dessas mulheres, incluindo pautas que dizem respeito ao racismo praticado no Brasil" (SCHWARCZ, 2019, p. 187).

Percebemos que todo esse processo de criação da identidade de gênero feminino tem como base a forma como os homens percebem as mulheres. Permeada pelas relações e percepções masculinas, elas passam a se entender a partir da imagem e da percepção que lhes são ensinadas.

\subsection{A MULHER NO DISCURSO DO OUTRO}

O entendimento do que é ser mulher e dos seus deveres é uma construção social que passa por modificações ao longo do tempo e que é pensado com base no período em que aquela sociedade está inserida. A autora Maria Rita Kehl discute em seu livro Os Deslocamentos do Feminino (2016) que esse significado pode mudar. Para ela, a inscrição dos sujeitos, os homens e as mulheres, pode mudar no discurso do outro, e essas modificações ocorrem ao longo da história. Kehl (2016) afirma que se essa mudança não alterar a estrutura da língua, ela vai alterar a forma como a língua será usada e isso se reflete nos lugares que a cultura influencia o sujeito.

Essas diferenciações que caracterizam as mulheres e os homens estão ligadas ao entendimento dos deveres e das características que são atribuídas a cada um. Os homens deveriam ter as qualidades da virilidade e independência, já para as mulheres caberia a inocência e a fragilidade que lhes eram destinadas. Kehl (2016) afirma que essa constituição do sujeito moderno e essa visão tradicional sobre a caracterização dos indivíduos teve início no final do século XVIII e se estendeu ao longo do século XIX. Os ideais que orientam a forma como as mulheres são vistas na sociedade são oriundos da cultura europeia e reforçam essa relação entre as mulheres e a 
feminilidade. Essas orientações fazem parte do imaginário social e são transmitidas pela educação, vivência familiar e religião; assim, as mulheres são criadas com base nessas normas.

\begin{abstract}
A feminilidade aparece aqui como o conjunto de atributos próprios a todas as mulheres, em função das particularidades de seus corpos e de sua capacidade procriadora; a partir daí, atribui-se às mulheres um pendor definido para ocupar um único lugar social - a família e o espaço doméstico -, a partir do qual se traça um único destino para todas: a maternidade (KEHL, 2016, p. 40).
\end{abstract}

Observando a forma como essas mulheres são enquadradas, percebemos como elas eram retratadas neste período e como a influência masculina insidia sobre a sua formação. Em palestra ministrada ao Instituto Vox ${ }^{4}$ em 2014, Kehl comenta que, nas sociedades do antigo regime, os destinos dos indivíduos eram traçados por meio do seu nascimento. Os filhos herdam as posições dos pais, sendo que o primogênito iria substituir o pai, o segundo iria para o clero e a filha era destinada ao casamento. E é na sociedade moderna que a possibilidade de escolha se torna o símbolo da liberdade que os indivíduos masculinos adquirem.

No caso das mulheres, o processo de emancipação feminina teve início na Revolução Francesa. Segundo Kehl (2016), foram as ideias filosóficas do Iluminismo que permitiram que elas se libertassem dos grilhões desses mandos da sociedade. A destinação da mulher ao lugar do lar é um ideal que vem sendo desenvolvido pelos pensadores ao longo do século XVIII e XIX, assim, Kehl apresenta que, na obra do historiador francês, Pierre Roussel, o fato central que colocava a mulher nesse lugar é a existência do útero.

Roussel representava a mulher como o oposto complementar do homem, tendo seu comportamento emocional e moral determinado pela presença deste órgão misterioso, o útero, a partir do qual se definia também o lugar social da mulher: o lar, a maternidade (KEHL, 2016, p. 45-46).

Como as naturezas masculinas e femininas são diferentes, restaria às mulheres serem ensinadas sobre seus deveres em relação à casa, ao marido e aos filhos. Esses ideais têm como base a construção social de que elas deveriam ser recatadas para reforçar a virilidade masculina e incentivar neles o instinto de proteção do lar. Para Kehl (2016), o modelo que orienta esse pensamento tem origem com Rousseau, que afirma que as mulheres que têm mais disposição a

\footnotetext{
${ }^{4}$ Vídeo disponível em: https://www.youtube.com/watch?v=o1yDVuY77Bc\&t=4s. Acesso em: 30 jan. 2020.
} 
serem influenciadas pela sua natureza e devem ser mais educadas de forma que continuem a reforçar e incentivar esse modelo de masculinidade.

\begin{abstract}
O modelo de Rousseau é tão perfeitamente articulado que escutamos até hoje suas ressonâncias. No século XIX, ele dominou, com uma série de variações mais ou menos científicas e/ou pedagógicas (aquele foi o século da medicina e da pedagogia), toda a produção de saberes sobre as mulheres (KEHL, 2016, p. 53).
\end{abstract}

Essa passagem nos permite entender que todo esse conhecimento criado sobre as mulheres carregava um discurso cientificista e pedagógico que legitimava a colocação das mulheres nesse lugar. Essa feminilidade, que seria natural às mulheres, é tratada por Kehl (2016, p. 56) como "uma construção discursiva produzida a partir da posição masculina, à qual se espera que as mulheres correspondam, na posição que a psicanálise lacaniana designa como sendo a do 'Outro do discurso"”. Elas estariam sempre do lado oposto dos homens. É interessante pensar nesse ponto, pois, se as mulheres estão na posição de contradição, os ideais iluministas que propõem a liberdade apenas para os homens.

Para ocupar esses espaços, as mulheres tiveram que aceitar que essas normas e deveres lhes fossem colocadas. Ao aceitá-las, elas se colocam em dois estados de alienação. Kehl (2016) apresenta que o primeiro estado de alienação está no sentido político de que ao se afastar dos espaços de tomada de decisão, elas permitem que os outros [os homens] escolham por elas. O segundo caso fica no âmbito da subjetividade, no qual, ao aceitar o lugar do Outro, elas se calam e renunciam à sua própria fala.

A autora recorre a John Stuart Mill (S/D) para comentar que, quando as mulheres se afastam e se deixam afastar da possibilidade de participação na esfera política, elas perdem os meios de garantir que elas se tornassem sujeitos de suas próprias vidas. Kehl (2016) apresenta que, no estudo de Peter Gay (S/D), os casamentos baseados nos ideais modernos passaram a realizar uniões baseadas no amor, assim muitos dos maridos passaram a incentivar que as esposas tivessem atributos masculinos, como a inteligência, iniciativa e a competência. Essa passagem nos faz pensar que, para as mulheres serem mais proativas e adquirir conhecimentos, elas têm que sair da sua posição feminina e adotar elementos que estão na esfera masculina do gênero, no sentido de quem as mulheres não podem ser inteligentes. Estes atributos são exclusivamente masculinos.

Além de tudo isso, ainda existia o entendimento de que, se as mulheres se tornassem cultas, elas iriam abandonar o espaço do lar e, consequentemente, o cuidado com os filhos e os maridos. 
Mulheres pensantes se configurariam enquanto um perigo para o lugar de dominação masculina e poderiam começar a se organizar em movimentos emancipadores influenciados pelas ideias iluministas.

É interessante observar que, embora o sustento material da família ainda dependesse, tradicionalmente, dos homens, o destino das mulheres estavam muito mais veementemente associado ao dever para com os filhos - para a continuidade da espécie, diríamos - do que o deles. Em nome desse dever, elas foram censuradas por querer limitar o número de filhos, por não desejar se casar, por ter vida social ou profissional e mesmo por estudar. Algum estudo era permitido às mulheres setecentistas, mas a erudição (esse discurso se radicaliza no século XIX) era imperdoável (KEHL, 2016, p. 63).

Michelle Perrot (2007), ao escrever a sua história das mulheres, comenta que teve dificuldade em encontrar relatos sobre elas. No entanto, a autora descobre que era difícil pois eles não eram feitos ou eram feitos pelos homens. Às mulheres ficavam destinados os espaços privados.

[...] porque as mulheres são menos vistas no espaço público, o único que, por muito tempo, merecia interesse e relato. Elas atuam em família, confinadas em casa, ou no que serve de casa. São invisíveis. Em muitas sociedades, a invisibilidade e o silêncio das mulheres fazem parte da ordem das coisas. É a garantia de uma cidade tranquila. Sua aparição em grupo causa medo (PERROT, 2007, p. 16-17).

O patriarcado exerce um domínio no qual as mulheres só podem escolher dentro do que os homens permitem, promovendo uma ideia de liberdade limitada. Entendemos o patriarcado conforme a definição que Christine Delphy (2009, p. 173) faz do termo, como “[...] uma formação social em que os homens detêm o poder, ou ainda, mais simplesmente, o poder é dos homens. Ele é, assim, quase sinônimo de "dominação masculina" ou de opressão das mulheres". O “'Patriarcado' vem da combinação das palavras gregas 'pater' (pai) e 'arkhe' (origem e comando)” (DELPHY, 2009, p. 174), expressão que define essa dominação do pai dentro da casa e que não se restringe apenas ao genitor, mas se estende a todas as figuras masculinas que podem exercer algum tipo de poder sob as mulheres. Porém, com a modernidade, elas começaram a ter acesso às informações que passaram a circular e usufruir de possibilidades que, antes, eram restritas aos homens.

Kehl (2016) compreende que os indivíduos são seres de linguagem e isso faz com que eles se tornem seres da história, que podem promover modificações no sentido das palavras de acordo 
com o seu contexto e a necessidade expressiva. E Judith Butler (2018) afirma que as formas de representação dominante da política e da linguística definem o modo como os próprios sujeitos são formados com base no que se pode conhecer como o sujeito.

A partir dessas reflexões, percebemos que é preciso entender o período no qual aquela palavra está inserida para compreender qual o seu real significado e quais as possibilidades que a sua representação pode criar. É importante, também, saber quais são essas características para identificar as formas como esses sujeitos são caracterizados.

\subsection{A ORIGEM DO ESTUDO SOBRE AS MULHERES}

Refletindo sobre os registros que foram feitos sobre as mulheres e, até mesmo, a falta deles, Michelle Perrot (2007) buscou delinear em seu estudo quem são essas mulheres que pouco se viam nos relatos da história. A autora comenta que essa busca significa a passagem do silêncio para as palavras e, também, para a mudança na forma de olhar para um novo surgimento de história, novos objetos de estudo e uma nova relação entre passado e presente.

Para realizar esse estudo, Perrot (2007) buscou investigar cinco áreas de conhecimento, como o silêncio e as fontes; o corpo; a alma; trabalho e criação e as mulheres na cidade. A autora comenta que falar dessas mulheres se constitui enquanto o rompimento de um silêncio no qual as mulheres estavam confinadas. A questão apontada por ela é que todos os tipos de relatos feitos ao longo dos anos contribuem para a existência de uma história, mas o ponto relevante é que não se relatava quase nada sobre essas mulheres. "Nesse silêncio profundo, é claro que as mulheres não estão sozinhas. Ele envolve o continente perdido das vidas submersas no esquecimento no qual se anula a massa da humanidade. Mas é sobre elas que o silêncio pesa mais. E isso por várias razões" (PERROT, 2007, p. 16).

Essa invisibilidade aconteceu porque as mulheres são menos vistas nos espaços públicos e por um longo período, as atenções eram voltadas para se relatar apenas os lugares da cidade. Em primeiro lugar, como as mulheres ficavam restritas ao lar, elas não eram vistas. E como elas não eram vistas, elas também não eram lembradas dentro das sociedades, e isso se configura o que Perrot (2007) chama de "o silêncio das fontes". As mulheres quase não deixam registros por escrito e os que eram feitos, em alguns casos, eram eliminados por elas mesmas. 
O que se sabe sobre as mulheres fica restrito aos relatos que os cronistas, homens, faziam delas. Dessa forma, o que se tem de registro das mulheres eram feitos de forma reduzida, repleta de estereótipos e promovendo uma diversidade de discursos que as generalizam. Para Perrot (2007), as mulheres são imaginadas e representadas ao invés de serem descritas ou contadas. Isso mostra como elas nem eram consideradas enquanto possíveis fontes para a construção da sua própria identidade, o que confirma a dissimetria sexual existente em nossa sociedade.

A autora comenta que, nos séculos XVIII e XIX, a história e o seu registro ganharam um ar mais científico e profissional, o que nos leva a pensar na questão da possibilidade de comprovação e veracidade das informações encontradas a partir desse período. No entanto, o que se percebe é que as mulheres ganharam um pouco de espaço nos relatos, mas a sua notoriedade ainda era bem pequena.

No século XIX, as biografias de mulheres foram um tema que passou a ser explorado no mundo da literatura, em especial de rainhas, cortesãs, santas e mulheres que tiveram algum tipo de destaque. Perrot (2007) comenta que foi nos anos de 1960 que houve o advento das histórias das mulheres na Grã-Bretanha e nos Estados Unidos, e, uma década depois, a França iniciou os seus estudos sobre as mulheres. Isso se deu por meio de três diferentes fatores que colocaram as mulheres enquanto objetos de estudo - o científico, o político e o sociológico.

Com relação aos fatores científicos, por volta de 1970, houve uma renovação e crise dos sistemas de pensamento do marxismo e estruturalismo, modificação das disciplinas e uma projeção da subjetividade. Houve a aliança da História com a Antropologia, que promoveu um redescobrimento da família, que funciona como uma medida das dimensões da história, dessa forma, "através da natalidade, da nupcialidade, da idade ao contrair núpcias, da mortalidade, a história aprendida, sem, no entanto, deter-se nisso, a dimensão sexuada dos comportamentos. Incidentalmente, colocava a questão das mulheres como sujeitos” (PERROT, 2007, p. 19). Essa mudança se iniciou com as escolas dos Annales, que começaram abordar a temática familiar e passaram a incluir novos atores na sua análise, como os jovens e as crianças, as dimensões da vida privada e as situações de cada geração. Dessa forma, com a mudança na questão intelectual, houve também uma transformação na forma de registrar a história.

No caso dos fatores políticos, eles foram bem decisivos para a época. A partir de 1970, houve um movimento de liberação das mulheres que não visavam a universidades e nem a questões históricas. No entanto, elas contavam com o suporte de mulheres intelectuais que eram leitoras do 
Segundo Sexo, de Simone de Beauvoir, e acreditavam que o livro propiciava toda solução. Na questão do saber, esse movimento buscou a ancestralidade e legitimidade como forma de recuperar alguns vestígios e fazer com que eles fossem visíveis para a nossa sociedade e, assim, um trabalho de registro dessa memória passou a ser feito como forma de manter viva essa memória das mulheres. Houve também ambições no campo teórico, que visavam reivindicar os saberes já constituídos, visto que eles eram de caráter predominantemente masculinos.

Com relação aos fatores sociológicos, a presença das mulheres foi o mais marcante. No início dos anos de 1970, elas eram um terço das alunas na França e, posteriormente, conquistaram o espaço dos docentes, após a Segunda Guerra Mundial. Perrot (2007) comenta que essa femininização pode ser o que incentivou uma demanda renovada ou uma escuta das questões das mulheres.

Pensando nesse apagamento que as mulheres sofrem, Perrot (2007) comenta que esta separação é algo que já está intrínseco até mesmo na nossa língua, o "eles", no plural, é utilizado quando há a mistura de gêneros. Os sujeitos femininos não são considerados maioria quando estão juntas com algum homem, o que mostra a hegemonia masculina dentro da própria linguagem; assim, ao representar o todo no masculino, desconsideramos as particularidades das mulheres na sociedade. Além disso, a memória delas também se vê destruída e negligenciada.

Ocorre igualmente uma autodestruição da memória feminina. Convencidas de sua insignificância, estendendo à sua vida passada o sentimento de pudor que lhes havia sido inculcado, muitas mulheres, no ocaso de sua existência, destruíam - ou destroem - seus papéis pessoais. Queimar papéis, na intimidade do quarto, é um gesto clássico da mulher idosa (PERROT, 2007, p. 22).

O que percebemos nesse panorama realizado por Perrot é que são elas mesmas que realizam o apagamento das suas memórias. $\mathrm{O}$ fato de cair sobre elas as regras da nossa sociedade relacionada à moral $\mathrm{e}$ aos costumes contribuiu para que os seus únicos registros existentes fossem apagados ou nem mesmo realizados. Por isso, os relatos e representações que falam delas são oriundos da mente masculina. Os arquivos que se têm sobre as escritas delas são em sua maioria cartas e diários que elas faziam para relatar das suas vidas, mas isso é uma escrita privada e que é praticada no silêncio dos lares e à noite. Seguindo a lógica do ambiente privado, Perrot $(2007$, p. 28) comenta que as “correspondência, diário íntimo, autobiografia não são gêneros especificamente femininos, mas se tornam mais adequados às mulheres justamente por seu caráter privado. De maneira desigual". 
Quando algum desses registros pode afetar a imagem e a moral delas, eles são eliminados, garantindo que a sua integridade e a da sua família sejam mantidas.

As correspondências se configuram enquanto escritas femininas, pois elas são responsáveis por escrever para os parentes distantes, ao marido que viaja e aos filhos que não moram mais em casa. Se corresponder com os parentes era algo permitido para as mulheres e isso se tornava uma forma de sociabilidade e expressão feminina. Elas também se configuram como meio de se corresponder com a pessoa amada, que está assegurada pela distância existente entre os dois sujeitos, garantindo que a integridade moral e física da mulher se mantenha. As cartas das mulheres não são publicadas, a não ser quando elas fazem alusão homens notáveis: "as correspondências femininas privadas raramente são publicadas, exceto quando põe em cena grandes homens: correspondência de François Guizot com sua filha Henriette, das filhas de Marx com o pai, Karl” (PERROT, 2007, p. 29). Isso nos faz perceber que, para existir a presença feminina, elas precisavam estar ligadas ao masculino; elas possuem algum tipo de destaque quando estão falando sobre algum homem, mas a sua essência permanece esquecida.

Escrever em um diário íntimo era algo recomendado pela Igreja e pelos protestantes, pois isso servia como um exercício de direção de consciência, reflexão e controle pessoal. No entanto, as educadoras laicas apontavam que isso poderia resultar em uma prática de introspecção excessiva das meninas. A escrita do diário permanece por um período limitado dentro da vida das mulheres, geralmente até que elas se casem e acabem perdendo esse espaço íntimo. Como eles se configuram enquanto espaço para se expressar a sua forma íntima, estes são alguns dos poucos registros em que as mulheres falam na primeira pessoa. Perrot (2007, p. 30) esclarece que é uma "voz em tom menor, mas de mulheres cultas, ou, pelo menos, que têm acesso à escrita. E cujos papéis, além do mais, foram conservados". Esse apanhado ainda mostra como os registros passavam pela relação de classes existentes na sociedade, de forma que os únicos registros permitidos eram feitos pelas mulheres que tinham o domínio da escrita.

Essa situação começa a se alterar no século XX, quando as mulheres começam a ocupar o espaço público, e foi também nesse período que Perrot (20072) afirma que se identificou a necessidade de se construir um arquivo sobre a história dessas mulheres. Para encontrar esses registros, foi preciso procurar não somente as leituras que elas faziam ou que se faziam delas, era necessário encontrar materiais que elas tivessem escrito. A autora comenta que a escrita, em primeiro momento, estava ligada à religião e ao imaginário, que se configuram como vias míticas 
e literárias. Essa história teve início na Idade Média, em que as mulheres que estavam no convento começaram a ter acesso à leitura e à escrita, e isso acabou mudando a configuração desses espaços; “os conventos diversificam sua clientela e sua função no século XVII, mas permanecem como centros de cultura para as mulheres, cada vez mais exigentes" (PERROT, 2007, p. 32). É interessante notar que são os espaços da religião que mais estimulam as mulheres a se manterem dentro das configurações das sociedades mais conservadoras e, em um momento da história, acabam por se tornar os espaços onde elas conquistam essa liberdade de aprender a ler e a escrever. Por mais que ele fique restrito a uma pequena parcela das mulheres, isso mostra o começo da sua ascensão nos ofícios relacionados à escrita e leitura.

\footnotetext{
O caminho encontra-se então aberto para as "mulheres que escrevem", para essas mulheres autoras que o século XIX misógino tentará, em vão, limitar e conter. Mulheres que, em sua maioria, são de origem aristocrática, com poucos recursos, e que tentam ganhar a vida de maneira honrosa com "a pena", tanto quanto com o pincel (PERROT, 2007, p. 32).
}

Além da disposição de algumas mulheres para escrever, a existência de um público feminino que lia os seus conteúdos as estimulava a produzirem. Mesmo ocupando um espaço no ofício da escrita, elas escreviam sobre culinária, moda, romances e o que mais deixasse as mulheres interessadas. Dessa forma, Perrot (2007) comenta que o feminismo presente nessa situação, mesmo sendo laico ou cristão, foi um poderoso incentivo para as mulheres, em especial no acesso à imprensa, que foi utilizado como modo de expressão.

A autora registra que foi sobre a temática de moda que se constituiu a primeira imprensa especializada feminina, no século XVIII. No primeiro momento, os homens eram responsáveis por esse tipo de escrita, mas, aos poucos, as mulheres começaram a se introduzir nesse espaço. Perrot (2007) comenta, como exemplo, o Journal des dames (1750-1778), em Paris, e o The Female Spectator (1744-1746), que foi publicado durante dois anos pela Eliza Haywood, em Londres. Seguindo essa linha, no século XIX, essa imprensa de moda adquiriu grande destaque entre as mulheres que buscavam por conselhos de moda. É possível perceber que o gênero da bibliografia também ganhou notoriedade nesse período e as personagens principais eram as rainhas e santas.

Por trás dessa fachada algo banal, observa-se, na escolha e no tom, uma vontade de emancipação das mulheres pela educação e mesmo pelo saber e pelo trabalho. Há conselhos para as jovens estudarem línguas estrangeiras porque a tradução é 
uma ocupação, eventualmente uma profissão, conveniente para a mulher. (PERROT, 2007, p. 33).

Nessa passagem, percebemos que as mulheres aos poucos utilizam as possibilidades do seu contexto social para buscar algum tipo de emancipação. Essas "brechas nas zonas proibidas" (PERROT, 2007, p. 33), como a autora comenta, são os espaços que as mulheres adquirem para se introduzir nesse espaço público. Mesmo sabendo que essas aberturas só existem porque algum homem permitiu, as mulheres aproveitam para tentar se fazer independentes. Dessa forma, as revistas femininas cresceram entre os séculos XVIII e XIX, visando a um público mais sofisticado e os patrocinadores utilizavam esse meio como forma de apresentar seus cosméticos e guiar o consumo das mulheres.

Perrot (2007) aponta que algumas mulheres que atuavam nessa frente da imprensa buscavam usar esse espaço para promover a emancipação feminina, como a Marcelle Auclair, da revista Marie Claire, que usava o "correio sentimental” para defender o direito à contracepção em um formato mais liberal. A autora destaca que isso se torna uma ambiguidade na imprensa feminina, atrelada à imagem e à conduta. Nesse sentido, percebemos que elas reforçam essa imagem das representações das mulheres por meio das matérias, mas, ao mesmo tempo, tentam criar um ambiente de modificação dessa situação desse contexto social. Dessa forma, Perrot (2007, p. 34-35) afirma que as feministas têm consciência do papel da imprensa na opinião pública.

Essa primeira imprensa feminista é muito original, não somente por seu conteúdo, mas também por sua apresentação. Além do uso antipatriarcal do patronímico, abre uma "tribuna das leitoras", que suscita muito interesse e manifesta a vontade de criar uma rede. Liberada pela lei de 1881, que funda o regime do jornalismo moderno, a imprensa feminista da Terceira República, estudada por Laurence Klejman e Florence Rochefort, é mais abundante.

Partindo desse espaço conquistado pelas mulheres, elas passam a ocupar um ofício que era exclusivamente masculino e adquirem um meio que pode ser utilizado para expressar as suas opiniões e fazer com que elas cheguem a outras pessoas.

O corpo das meninas sempre foi algo a ser escondido de toda a sociedade, como vimos em relação aos seus relatos, e, com o avançar da idade, elas começam a ser representadas na literatura. Dessa forma, as jovens são muito mais representadas do que as meninas nos romances, como os que foram escritos por Jane Austen, Kafka, Balzac ou George Sand, como aponta Perrot (2007). A 
puberdade é um momento de dualidade na vida das mulheres: ao mesmo tempo em que marca a existência delas, ela também não é celebrada pela sociedade, que preferia ignorar a sua existência. A historiadora comenta que foi somente a partir dos anos 1970 que o assunto menstruação passou a ser tema de conversas entre mães e filhas, que os primeiros produtos foram apresentados e que se começou a publicizar as formas de proteções.

$\mathrm{Na}$ questão da sexualidade, a virgindade das moças era algo cobiçado e que deveria ser guardado. A violação desse bem não era visto com bons olhos e, dessa forma, as mulheres que realizavam o ato sexual antes do casamento tinham poucas chances de conseguir algum matrimônio.

As atividades que cada uma realizava se diferenciavam pelas classes sociais nas quais elas estavam inseridas; assim, as jovens aristocratas e solteiras possuíam um preceptor ou governanta que tomavam conta delas enquanto elas montavam a cavalo e praticavam esgrima. As jovens burguesas solteiras eram educadas pelas mães, realizavam atividades domésticas, eram introduzidas às artes, em especial ao piano, estudavam nos colégios internos e, quando começavam a frequentar a sociedade, o objetivo delas era conquistar um casamento. Já as moças das classes populares começavam a trabalhar cedo.

O casamento é visto como o ápice da vida das mulheres e a solução para a melancolia e anorexia, que são males que acometiam sobretudo as solteiras. Segundo Perrot (2007), em 1900, na França, o casamento era a condição normal das mulheres e a união arranjada era comum para selar alianças entre as famílias. Já a união por amor não era considerada tão usual. Caso o amor estivesse presente, ele não seria o principal motivo pela união de duas pessoas. As mulheres que escolhiam o celibato eram consideradas desprezadas, solteironas e boas tias, e optar por esse caminho era algo difícil, visto que era preciso que elas obtivessem certa independência econômica.

Ocorre uma longa e lenta expansão do casamento por amor, processo no qual as mulheres do século XIX têm um papel determinante, e cuja apologia é feita por romancistas como Jane Austen e George Sand. Sinal claro da individualização das mulheres, e também dos homens, o casamento por amor anuncia a modernidade do casal, que triunfa no século XX (PERROT, 2007, p. 47).

Ao se casarem, as mulheres se tornam parte da família dos seus maridos, elas perdem seu sobrenome, colocam-se na posição de donas de casa e dependentes e possuem, sobretudo, o dever da maternidade, que completa todas as características da feminilidade que devem ser segundo a 
construção de tal modelo normativo. Com a chegada da menopausa, a feminilidade, maternidade, sensualidade e sexualidade delas acabam, conforme se acreditava no século XIX.

Quando falamos da representação do sexo feminino, Perrot (2007) faz uma reflexão que vai de Aristóteles a Freud, que apresenta que esse sexo é uma carência, uma fraqueza e um defeito. "Para Aristóteles, a mulher é um homem malacabado, um ser incompleto, uma forma malcozida. Freud faz da 'inveja do pênis' o núcleo obsedante da sexualidade feminina” (PERROT, 2007, p. 63). A mulher é vista com um ser inacabado e que não é igual ao corpo masculino, o seu destino está ligado exclusivamente à geração de um sujeito, sendo esta a sua grande importância social.

A maternidade é um momento e um estado para as mulheres que dura para além da concepção e se arrasta ao longo de suas vidas. As sociedades ocidentais colocam a maternidade em um lugar de destaque dentro do nosso contexto, e essa relação tem a ver com a figura da Virgem Maria para a Igreja Católica, na qual se vê a pureza da concepção sem que tenha acontecido um ato sexual.

O corpo das mulheres é subjugado, dominado e roubado em sua própria sexualidade e, conforme apresenta Perrot (2007, p. 76), "o que muda é o olhar lançado sobre elas, o limiar de tolerância da sociedade e o das mulheres, a história de sua queixa". As representações que vemos nos dias de hoje são construídas por meio da forma como os homens viam e identificavam essas mulheres. A autora comenta que a religião e as mulheres sempre tiveram uma relação mais paradoxal, pois eram espaços de poder das mulheres e, ao mesmo tempo, sobre as mulheres. Partindo dessa reflexão, algumas religiões, em especial católicas e islâmicas, eram, em sua maioria, masculinas, porém, mesmo com essa dominação por parte dos homens, as mulheres poderiam usar esses espaços para se encontrar, cantar no coral e aprender a ler e a escrever.

Perrot (2007) comenta que, ao final dos anos de 1880 e início de 1900, houve o aumento da escolarização das mulheres, que começou no primário e se estendeu até a formação superior. Dessa forma, a presença delas dobrou nas universidades no período entre guerras. A autora comenta que isso pode ser reflexo da modernidade, que estava se iniciando no período, assim, os homens buscavam "mulheres inteligentes" e o Estado queria que elas trabalhassem na Educação Básica. Além disso, outros setores como o terciário as contratavam para atuar no ramo de serviços, como secretárias, correios e datilógrafas. 


\section{FEMINISMOS PLURAIS}

O feminismo é um movimento plural que contempla as principais questões das mulheres de um determinado país, estado, cidade e tempo. Neste capítulo, vamos apresentar o que é o movimento do feminismo em países como Inglaterra, França e Estados Unidos a partir das autoras Céli Regina Jardim Pinto (2010) e Adriana Piscitelli (2008). Depois, faremos uma contextualização histórica sobre a mulher no Brasil do século XX com base em Maria Ângela D’Incao (2004) e Lilia Schwarcz (2012). Nesta parte, buscamos mostrar quais eram as condições e deveres da mulher no início da década de 1910, pois, devido ao período histórico, aproxima-se dos valores apresentados pelos personagens de Orgulho e Paixão e as formas de fazer seu tensionamento. Continuamos nossa caminhada com as mulheres até os dias contemporâneos com Mirla Cisne (2015) e Lilia Schwarcz (2019) para apresentar mais sobre os caminhos percorridos por elas e o que as fez chegar até o século XXI. Optamos por falar em feminismos plurais por entendermos que essas correntes se manifestam de acordo com a necessidade de cada grupo de mulheres em um determinado período de tempo. Com isso, podemos acompanhar o surgimento, por exemplo, do feminismo negro, que aconteceu somente no século XXI, como apresenta Schwarcz (2019).

\subsection{AS ONDAS FEMINISTAS NA EUROPA E NOS ESTADOS UNIDOS}

Perrot (2007) nos apresenta uma trajetória do estudo sobre a história da mulher em que elas passam da condição de representadas pelos homens dentro da nossa sociedade para o início da sua aparição no espaço público. Como comenta Céli Regina Jardim Pinto (2010), sempre houve mulheres que se rebelaram contra a condição na qual elas foram colocadas e buscaram pela liberdade, no entanto muitas delas tiveram que pagar com a própria vida. Para a autora, a "Inquisição da Igreja Católica foi implacável com qualquer mulher que desafiasse os princípios por ela pregados como dogmas insofismáveis" (PINTO, 2010, p. 15).

Pinto (2010) aponta que a primeira onda do feminismo começou na Inglaterra, quando as mulheres começaram a se organizar para lutar pelos seus direitos, a partir das últimas décadas do século XIX. A sua primeira reivindicação era o direito ao voto e esse grupo de mulheres ficou conhecido como as "sufragetes". Elas realizaram grandes manifestações em Londres e, em 1913, uma feminista chamada de Emily Davison se atirou na frente do cavalo do Rei e morreu na corrida 
em Derby para mostrar a luta pelas suas causas. Em 1918, as mulheres conquistaram o direito ao voto no Reino Unido.

Entre os 30 anos que separam a primeira da segunda onda do feminismo, o livro O Segundo Sexo, de Simone de Beauvoir, foi publicado, e essa obra foi fundamental para o surgimento do segundo movimento. Pinto (2010) explica que Beauvoir estabeleceu um dos principais pensamentos do feminismo, que é "não se nasce mulher, se torna mulher", dando perspectiva para novas formas de pensar no feminismo.

Adriana Piscitelli (2008) apresenta que o pensamento feminista que estava vinculado ao marxismo e ao socialismo sempre considerou as diferenças de classe, e a segunda onda do feminismo ocorreu entre as décadas de 1960 e 1980. Para a autora, nesse contexto, as mulheres já conquistaram os direitos na maioria dos países perante a lei. Piscitelli (2008) recorre a Beechey (1979) para afirmar que as feministas radicais concediam a primazia ao patriarcado e focaram nas diferenças sexuais, e as socialistas voltaram a sua atenção para as diferenças de classes entre as mulheres e faziam a relação entre o patriarcado e o capitalismo.

Essas ideias são relevantes porque remetem à centralidade concedida à diferença sexual, em termos universais, por algumas correntes do pensamento feminista. Observe-se, porém, que a raça é tratada como se apenas oferecesse elementos para estabelecer analogias, comparações entre formas dessa opressão, em diversas formulações feministas (PISCITELLI, 2008, p. 265).

Nesse sentido, Piscitelli (2008) destaca que é necessário prestar atenção na fala de Gayle Rubin (1975), que afirma que é importante se atentar para as diferenças raciais e que é preciso unir os movimentos feministas, negros americanos, indígenas americanos e das pessoas de terceiro mundo, criando a perspectiva para movimentos mais plurais.

Para Pinto (2010), a segunda onda ocorreu na década de 1960, que foi um período importante para o mundo ocidental. Os Estados Unidos iniciaram a Guerra do Vietnã e também viu surgir o movimento hippie, que "propôs uma forma nova de vida, que contrariava os valores morais e de consumo norte-americanos, propagando seu famoso lema: 'paz e amor'” (PINTO, 2010, p. 16).

O maio de 68, na Europa, foi destacado por Pinto (2010) como os período em que estudantes ocuparam Sorbonne e questionaram a ordem acadêmica que era estabelecida e a desilusão com os partidos burocratizados da esquerda comunista. A autora ressalta que, nesse mesmo momento, os 
estudantes tentaram uma aliança com os operários e houve o lançamento da pílula anticoncepcional nos Estados Unidos e, depois, na Alemanha. A reflexão da autora é de que "durante a década (1960), na Europa e nos Estados Unidos, o movimento feminista surge com toda a força, e as mulheres pela primeira vez falam diretamente sobre a questão das relações de poder entre homens e mulheres" (PINTO, 2010, p. 16). Ela afirma que o feminismo surge como um movimento libertário, que além de buscar a conquista pelo espaço da mulher, no trabalho, educação e na esfera pública, luta também pela reformulação no relacionamento entre homens e mulheres, no qual elas possam ter autonomia.

A terceira onda do feminismo acontece no final da década de 1990 e surge por meio da perspectiva de que as mulheres são diversas. A autora Schwarcz (2019) destaca que podemos identificar nesse período a emergência de movimentos que lutam por reconhecimento nesse cenário atual, como o feminismo negro. E Piscitelli (2008, p. 263) completa essa afirmação ao apontar que o final do século XX foi "marcado pela emergência de categorias que aludem à multiplicidade de diferenciações que, articulando-se a gênero, permeiam o social”, que são categorias de articulação nas interseccionalidades.

Piscitelli (2008) afirma que os questionamentos da distinção entre sexo e gênero se iniciaram ao final da década de 1980, e tiveram como um dos focos o estabelecimento de que a diferença entre as identidades de gênero tinha como base a questão biológica, que dividia em dois gêneros. Para a autora, as obras produzidas nesse período buscavam questionar os pressupostos das primeiras formulações de gêneros, as perspectivas que estavam sendo usadas como base para as linhas de análise feminista e a centralidade que foi concedida ao gênero no que se refere às forças sociais que oprimem as pessoas.

A autora destaca que "algumas antropólogas chamaram a atenção para o fato de que a compreensão do gênero ocidental, incluindo o pensamento feministas, está ligada não apenas às relações entre os sexos, mas a idéias mais gerais sobre como a cultura é diferente de e superior à natureza" (PISCITELLI, 2008, p. 264). Para ela, as reelaborações teóricas não incorporam as outras diferenças que iam além da sexual. Essa reflexão leva Piscitelli (2008) até Joan Scott (1988), que propõe em sua análise a possível emergência de uma nova história que tivesse novas questões que estivessem em conjunto com a uma visão de igualdade que também incluísse a classe e a raça. Nessa perspectiva, Piscitelli (2008) também recorre a Donna Haraway (1991), que afirma que a centralidade na categoria gênero acaba por subordinar as outras, que acabam surgindo da política 
da diferença. Podemos perceber que essa organização cria uma hierarquia de categorias dentro desse contexto. E, nessa perspectiva de questionamento das autoras, Piscitelli (2008) evidencia que a indagação das categorias analíticas permitiu a formulação de conceitos e categorias que podem ser de articulação e/ou interseccionalidades.

\begin{abstract}
A proposta de trabalho com essas categorias é oferecer ferramentas analíticas para apreender a articulação de múltiplas diferenças e desigualdades. É importante destacar que já não se trata da diferença sexual, nem da relação entre gênero e raça ou gênero e sexualidade, mas da diferença, em sentido amplo para dar cabida às interações entre possíveis diferenças presentes em contextos específicos (PISCITELLI, 2008, p. 266).
\end{abstract}

Nesse sentido, percebemos que a interseccionalidade surge como uma possibilidade para as diversas abordagens para a realização das análises. A autora comenta que, na perspectiva de Kimberlé Crenshaw (2002), as interseccionalidades são formas de retratar os resultados das interações de duas ou mais subordinações, como o sexismo, patriarcalismo e racismo. Piscitelli (2008, p. 267) evidencia que, para Crenshaw (2002), a interseccionalidade é vista como "[...] diversas avenidas, em cada uma das quais circula um desses eixos de opressão. Em certos lugares, as avenidas se cruzam, e a mulher que se encontra no entrecruzamento tem que enfrentar simultaneamente os fluxos que confluem, oprimindo-a".

A outra abordagem é apresentada pela própria Piscitelli (2008, p. 268) como sendo a construcionista, na qual "os processos mediante os quais os indivíduos se tornam sujeitos não significam apenas que alguém será sujeito a um poder soberano, mas há algo mais, que oferece possibilidades para o sujeito". Isso nos leva a perceber que os marcadores de identidade, como o gênero, etnicidade e classe, não são apenas formas de categorização que limitam, eles também dispõem de recursos que possibilitam a ação.

Nessa perspectiva, uma outra autora que Piscitelli (2008) destaca é a Avtar Brah (2006), que propõe trabalhar a "diferença" como uma categoria analítica. Segundo a autora, "essa ideia remete à análise de como as formas específicas de discursos sobre a diferença se constituem, são contestados, reproduzidos e (re)significados, pensando na diferença como experiência, como relação social, como subjetividade e como identidade" (PISCITELI, 2008, p. 269).

A filósofa Djamila Ribeiro (2017) afirma que tirar essas pautas da invisibilidade e ter um olhar interseccional é importante para que análises simplistas e considerações universalizadas não sejam feitas. Para Ribeiro (2017), quando 
[...] a história tem nos mostrado que a invisibilidade mata, o que Foucault chama de deixar viver ou deixar morrer. A reflexão fundamental a ser feita é perceber que, quando pessoas negras estão reivindicando o direito a ter voz, elas estão reivindicando o direito à própria vida (RIBEIRO, 2017, p. 26).

Para a filósofa, ao refletir sobre a interseccionalidade, as intelectuais passaram a pensar em diferentes formas de sociabilidade e não somente nas opressões estruturais que estão no modo de isolamento. Seguindo essa perspectiva de pensar na posição da mulher dentro da estrutura social, Ribeiro (2017) argumenta que a mulher negra está em um não lugar.

A partir desse levantamento bibliográfico e das contribuições que privilegiam a narrativa de pesquisadoras sobre a questão da mulher, percebemos a pluralidade existente entre os movimentos feministas que se iniciaram a partir do final do século XIX. Passando pelas intelectuais e pelos movimentos que buscam reconhecimento dentro do próprio feminismo, cada onda do feminismo busca por algum direito dentro da sociedade.

\subsection{A CONTEXTUALIZAÇÃO DO FEMINISMO NO BRASIL}

A modernização no Brasil começou no século XX e promoveu profundas mudanças no perfil da população. Influenciada em grande parte pela abolição da escravidão, que ocorreu em 1888, a imigração foi incentivada principalmente para os europeus que vinham trabalhar na economia cafeeira.

O modelo preconizado pela República, que se iniciou em novembro de 1889, pautou-se pela exclusão de largos setores sociais, sempre em nome de uma política que priorizasse uma nova modernidade e racionalidade. Nesse sentido, se não há como negar que a Primeira República promoveu processo acelerado de institucionalização, largas faixas da população viram-se, ainda, que com acesso à liberdade e à igualdade jurídica, excluídas do jogo social que então se montava (SCHWARCZ, 2012, p. 35).

O período foi marcado pela abordagem de teorias como o darwinismo racial e higienismo, que acabavam por fazer denúncias com relação à mistura e miscigenação do povo brasileiro. Os modelos foram ensinados nas instituições de Ensino Superior do país, o que gerou um receio de conviver com os imigrantes e os escravos livres. Segundo Schwarcz (2012), esse período também foi marcado pelo entusiasmo pelo progresso e futuro, que já gerava alguns efeitos nas cidades. Outro ponto importante é que o imigrante tinha uma relação de dualidade entre a questão da 
miscigenação e a do melhoramento, que era configurado pelo branqueamento da população. A autora comenta que esse período foi nomeado de "regeneração", que levou a alteração do perfil das grandes cidades brasileiras, com uma arquitetura e urbanização inspirada na moda francesa.

Schwarcz (2012) afirma que, devido à crise agrária, à seca e às novas oportunidades da cidade, a população do campo se moveu em direção à cidade, e esse movimento deu origem a novos conglomerados urbanos que criaram um desarranjo e desordem no cenário urbano. Moradias irregulares e uma população inusitada passou a transitar pelas ruas e a conviver com essa nova burguesia emergente, como comenta a historiadora,

[...] mas, se havia alguma dúvida no ar, a atmosfera geral era de euforia, assim como pairava a certeza, por parte das novas elites que ascenderam como República, de que o Brasil "andava a braços" com os novos ditames do capitalismo, do progresso e da civilização (SCHWARCZ, 2012, p. 39).

Ainda de acordo com a autora, os novos cenários urbanos e as vestimentas eram inspirados na última moda parisiense, os automóveis, lojas, restaurantes, teatros e edifícios dividiam espaço com o que era chamado de sertão, aquela parte do Brasil que foi esquecida com esse progresso, que era composto de indígenas, mulatos e libertos. "Modernização e tradição eram conceitos fortes nesse momento que previa mudanças, mas experimentava continuidades de toda ordem" (SCHWAZRCZ, 2012, p. 41), o momento era de dualidade, o que estava sendo colocado em questão eram os valores antigos com os modernos, que vinham com essa influência de imigrantes, principalmente europeus, no Brasil.

A urbanização já era uma realidade que veio para alterar essa configuração tradicional que existia no país. O destaque para esse processo de desenvolvimento voltou-se para as cidades de Rio de Janeiro, São Paulo e, posteriormente, Belo Horizonte. Schwarcz (2012) destaca que, no final da década de 1880, São Paulo se tornou uma metrópole do café e acabou recebendo muitos imigrantes que buscavam trabalho. No entanto, com a crise no setor cafeeiro, as pessoas que foram trabalhar na lavoura voltaram para a capital paulista em busca de novas oportunidades para trabalhar nas áreas em que eles se especializaram nos seus países de origem. No caso das migrações internas, a região Nordeste perdeu a maior quantidade de pessoas entre os períodos de 1872 e 1900 devido ao fim da escravidão e da economia de açúcar. Essas pessoas se dirigiram para o Amazonas, Rio de Janeiro e São Paulo em busca de novas oportunidades. 
Schwarcz (2012) afirma que, entre 1890 até a Primeira Guerra Mundial, período nomeado como belle époque, o sentimento era de que a prosperidade era o que caminho que estavam seguindo e sonhos ilimitados foram criados. Esse momento, no Brasil, era chamado de "regeneração", que aparentemente correspondia ao resto do mundo e criava a sensação de que o país estava seguindo a harmonia e a civilização, e a jovem República se afastava da monarquia e da escravidão. Para a autora, o desenvolvimento que ocorreu no estado de São Paulo se deu por três motivos: o primeiro era a expansão cafeeira, saída do Paraíba até o Oeste Paulista, no final de 1850; o segundo era a implantação da estrada de ferro, que permitia a maior movimentação interna; e por último, a imigração, que promoveu mudanças no dialeto, serviços públicos e culinária paulistana.

Todas essas alterações - sociais, culturais, tecnológicas e econômicas - levaram, por sua vez, a mudanças aceleradas no comportamento da população local, que passou a transitar pelas ruas da cidade, deixando o ambiente exclusivo da casa patriarcal. Também em São Paulo (e em ritmo paralelo ao que ocorria no Rio de Janeiro) a "boa sociedade" descobriu novos hábitos: os bailer, o turfe, o trottoir e a noitadas no teatro (SCHWAZRCZ, 2012, p. 47).

Com todo esse movimento que promoveu mudanças na sociedade brasileira e que refletiu na forma como a população iria se movimentar dentro desse espaço, os padrões de sociabilidade antigos ainda permaneciam intrínsecos, com os valores do mundo rural escravocrata e do patriarcado brasileiro. "Ao lado das novas tecnologias, das atividades econômicas e ocupações sociais mais recentes - e propriamente urbanas - permaneciam os rastros de um passado revigorado, em que as hierarquias sociais eram dadas por padrões rígidos de nascimento e inserção" (SCHWARCZ, 2012, p. 47). Nesse sentido, as mudanças ocorriam dentro do espaço público no Brasil, na economia e na estrutura arquitetônica e urbanística, mas a estrutura social e os valores que já estavam arraigados na sociedade permaneciam os mesmos, oriundos de um país que era considerado atrasado.

Esse processo de modernização resultou na mudança da forma como as próprias cidades se organizavam. O embelezamento destas foi um processo que resultou na expulsão dos pobres e demolição dos casebres para darem lugar a largas avenidas e praças, como a Avenida Paulista, onde foram construídos casarões imponentes. A mudança no hábito das cidades não acompanhou esse processo de modernização estrutural que o Brasil estava passando. Os mesmos valores e morais do país escravocrata e patriarcal, que não condizem com essas transformações, ainda 
permaneciam frescos no dia a dia dessa população, reforçando ainda mais a dualidade entre tradição e modernidade. Cabe questionar, então: como as mulheres eram retratadas dentro desse contexto pós proclamação da República no Brasil, urbanização e modernização?

\subsection{AS MULHERES NO BRASIL REPÚBLICA: COSTUMES E VALORES DA SOCIEDADE}

Com as mudanças ocorridas ao longo do século XIX, o Brasil passou por algumas transformações que Maria Ângela D'Incao (2004, p. 187) denomina como:

[...] consolidação do capitalismo; o incremento de uma vida urbana que oferecia novas alternativas de convivência social; a ascensão da burguesia e o surgimento de uma nova mentalidade - burguesa - reorganizadora das vivências familiares e domésticas, do tempo e das atividades femininas; e, por que não, a sensibilidade e a forma de pensar o amor.

No início desse período quase não existia vida urbana no Brasil, que era controlado pelo grande setor rural. A elite que dominava a sociedade brasileira era marcada pela influência do que se imaginava que era a aristocracia portuguesa adaptada à realidade nacional, nas fazendas e no sistema escravista, e a família patriarcal nacional era comandada pelo pai, que exercia o poder sobre os escravos e a família, separados entre casa-grande e senzala.

D’Incao (2004) apresenta que, nos anos próximos ao século XIX, as cidades eram uma extensão das áreas rurais, mas ainda não ofereciam oportunidades para os trabalhadores e não existiam leis que fizessem algum tipo de regulamentação desse espaço e nem mesmo a limpeza local. Com a criação da Faculdade de Medicina no Brasil, as ideias relacionadas às questões de higiene começaram a se espalhar pela classe alta da sociedade, assim, medidas higiênicas foram tomadas e a sociedade urbana adquiriu uma nova face; essas medidas permitiram que novos valores fossem implantados. A autora evidencia que na passagem do século XIX para o XX, o processo de modernização da capital, o Rio de Janeiro, intensificou-se a partir da emergência da República e, com isso, o ideal de ser civilizado e de modificar a capital conforme os grandes centros europeus se tornou um dos objetivos após a implantação do novo regime político. Além das mudanças na estrutura da cidade, as relações sociais passaram das senhoriais para as burguesas, e isso significava a rejeição dos comportamentos tradicionais e a busca por relações mais modernas que afetaram a vida familiar. 
A cidade adquiriu o status de espaço público e a casa era o âmbito privado. O lugar público era o de interesse, de trabalho e de relações entre as diversas pessoas que passavam pela cidade e isso contribuiu para criar a desconfiança que temos em relação aos "outros” ou ao desconhecido.

O desenvolvimento das cidades e da vida burguesa no século XIX influiu na disposição do espaço no interior da residência, tornando-a mais aconchegante; deixou ainda mais claros os limites do convívio e as distâncias sociais entre a nova classe e o povo, permitindo um processo de privatização da família marcado pela valorização da intimidade (D’INCAO, 2004, p. 190).

O espaço privado era valorizado porque, nele, as pessoas não precisavam manter as mesmas relações sociais como na cidade, e essa separação incentivou a criação de círculos de amizade baseados nos estratos sociais. Com isso, houve a prerrogativa para a criação de salas de visita e salões que eram espaços que realizavam o intermédio entre lar e rua, para que as pessoas se encontrassem e se relacionassem por meio de eventos sociais, como jantares, festas e saraus.

Mesmo com essa nova forma de se relacionar dentro das cidades, sobre as mulheres, os mesmos dogmas de serem vigiadas permaneciam nesses novos espaços, segundo D’Incao (2004). Pensava-se que elas teriam mais liberdade nessa sociedade moderna, mas o que mudava era que elas se viam mais expostas aos olhares dos outros.

\footnotetext{
Nesses lugares, a ideia de intimidade se ampliava e a família, em especial a mulher, submetia-se à avaliação e opinião dos "outros". A mulher de elite passou a marcar presença em cafés, bailes, teatros e certos acontecimentos da vida social. Se agora era mais livre - "a convivência social dá maior liberalidade às emoções" -, não só o marido ou o pai vigiavam seus passos, sua conduta era também submetida aos olhares atentos da sociedade. Essas mulheres tiveram de aprender a comportar-se em público, a conviver de maneira educada (D'INCAO, 2004, p. 191).
}

O casamento que ocorria entre as famílias ricas da burguesia era como uma forma de ascensão social, priorizando as uniões por interesse muito mais do que as por amor. Neste contexto, as mulheres casadas recebiam a função de serem esposas exemplares, boas mães e realizar a mobilidade social por meio da convivência nos salões e como anfitriãs. Com isso, percebemos que os ideais de que uma mãe dedicada e atenciosa são reforçados e continuam caindo sobre as mulheres, e isso pode ser atingido somente na esfera da família burguesa e higienizada, da mesma forma que Perrot (2007) destaca como sendo a exaltação da maternidade na sociedade. 
Da esposa do rico comerciante ou do profissional liberal, do grande proprietário investidor ou do alto funcionário do governo, das mulheres passa a depender também o sucesso da família, quer em manter seu elevado nível e prestígio social já existentes, quer em empurrar o status do grupo familiar mais e mais para cima (D’INCAO, 2004, p. 191).

Além de ter que agir conforme os padrões de conduta impostos para as mulheres, elas ainda tinham o papel de promover a imagem dos seus maridos dentro do espaço social. O prestígio que elas adquiriram para seus maridos, em forma de capital simbólico, era apenas uma parte dos seus deveres, sobretudo o poder e a autoridade ainda eram mantidos nas mãos masculinas, "considerada base moral da sociedade, a mulher de elite, a esposa e mãe da família burguesa deveria adotar regras castas no encontro sexual com o marido, vigiar a castidade das filhas, constituir uma descendência saudável e cuidar do comportamento da prole" (D’INCAO, 2004, p. 192).

As mulheres, como abordamos anteriormente, deveriam ser bem cuidadas e mantidas no espaço do privado até o casamento, ou seja, até que as alianças políticas e econômicas fossem realizadas. Nesse sentido, é importante que a virgindade feminina fosse mantida dentro do acordo e não poderia haver contato entre as mulheres e os homens sem que houvesse a presença de alguém. D’Incao (2004, p. 197) afirma que os encontros dos casais não eram aceitos, pois não havia nenhum tipo de "intermediação" que pudesse separar esses corpos. Dessa forma, quando eles se encontravam, a partir de uma falha no sistema de vigia, eles ameaçavam a realização de qualquer aliança política e econômica que as famílias esperavam.

Para a autora, esse processo documentado de vigilância e o seu afrouxamento aconteceu ao longo do século XIX. A partir da ascensão da burguesia e da mudança dos valores da época, os casamentos continuavam sendo por interesse, porém a vigilância diminui, pois as mulheres começaram a se autovigiar. D'Incao (2004) explica que elas começaram a se comportar diante da sociedade - caracterizando o enraizamento desse tipo de costume.

Com o passar do tempo, o casamento ainda é feito por meio de interesse, mas a participação em diferentes ciclos sociais se ampliou entre as mulheres, as jovens conquistaram empregos mais liberais e as normas de comportamento ficam mais tolerantes, contanto que elas ainda mantenham os costumes e a aparência. Percebemos que, por meio da adoção dos costumes de se preservar, as mulheres não necessitam mais de vigilância, visto que elas moldaram o seu comportamento a partir da forma como a sociedade ditava. Entender como surgiram as formas de representação das 
mulheres é uma das chaves para conseguir compreender os padrões de conduta que são esperados delas nos dias de hoje.

\subsection{O MARCO PARA A MULHER BRASILEIRA: A TOMADA DA CONSCIÊNCIA}

Em um contexto em que existem diversas relações sociais e de classe estabelecidas na sociedade brasileira, Mirla Cisne (2015, p. 51) afirma que o feminismo discute questões para a apreensão e formulação de categorias teóricas que têm como objetivo a "compreensão crítica da subordinação histórica e das desigualdades que marcam a vida das mulheres, como forma de se instrumentalizar para intervir politicamente na reversão dessa condição".

Para entender esse cenário, a autora comenta que as mulheres e os homens são marcados por relações de alienação e dominação ideológicas, e chama a atenção ao pontuar que as mulheres carregam consigo a "força da ideologia de uma suposta natureza feminina" (CISNE, 2015, p. 17) e que esses sujeitos são constituídos enquanto seres apolíticas, submissas e passivas. Cisne (2015) recorre a Iasis (1999) e salienta que a alienação é tida como a consciência subjetiva que é enraizada com questões afetivas e baseada em modelos. Já a ideologia atua sobre essa base da alienação e introduz as suas características dentro desse sistema.

Ao pensar sobre a dominação da mulher, podemos refletir sobre o poder de influência do patriarcado, e Cisne (2015, p. 63) evidencia que "a origem do patriarcado, portanto, está radicalmente ligada à apropriação masculina sobre o corpo da mulher [...]". Como podemos acompanhar ao longo dessa reflexão sobre a história das mulheres, concordamos a autora quando ela aponta que "[...] as mulheres são sínteses das relações que estabelecem, mediadas por uma sociedade alienante e alienadora" (CISNE, 2015, p. 67).

Para ela, a própria família pode ser entendida enquanto uma estrutura que promove a exploração da mulher. Nesse sentido, Cisne (2015, p. 68) busca em Danda Prado (1985) o significado da palavra "família", que é oriunda do latim "famulus", que significa "conjunto de servos e dependentes de um chefe ou senhor". Com isso, percebemos que o próprio significado da palavra estabelece uma hierarquia dentro das relações sociais, na qual o homem é colocado na posição mais alta e de dominação. Cisne (2015, p. 69) evidencia que para "para conseguir manter esse 'sistema incontestável' de valores, a família conta com a ideologia de que é o 'lugar de aconchego e paz"”. 
Essas relações familiares são como prisões para as mulheres e o trabalho doméstico se torna uma forma de exploração que elas sofrem. Para Cisne (2015), a família explora economicamente as mulheres e isso acontece por meio dos trabalhos domésticos, que não são remunerados, e pela responsabilidade que elas têm de cuidar dos filhos, idosos e qualquer sujeito inválido. A autora comenta que "ainda que novas configurações familiares estejam em forte curso histórico, a família permanece como uma significativa instituição na garantia da estrutura para a divisão sexual do trabalho e, por extensão, da reprodução social" (CISNE, 2015, p. 70).

Partindo dessa interação entre a ideologia que é influenciada pela classe dominante, a autora ainda destaca que a cultura não pode ser uma esfera abstrata e isolada das questões e relações estruturadas dentro da sociedade. É necessário entender quem domina as relações e criam as ideologias para compreender como elas são constituídas, pois "evitamos cair na sedução da naturalização da cultura ou do relativismo cultural, que a considera como algo que não pode ser alterado" (CISNE, 2015, p. 78).

Entendemos o patriarcado enquanto a ideologia dominante que atua nesse período em análise, e essa cultura de dominação fica naturalizada devido ao enraizamento das ideias e das organizações sociais que estiveram dentro da nossa sociedade. A partir dessa afirmação de ideologia, a possibilidade de pensar de forma transformadora se torna difícil. Cisne (2015) evidencia que é preciso entender criticamente a desnaturalização dos sexos e da subordinação da mulher, do racismo e da heterossexualidade compulsória para combater essas relações de dominação.

Para entender como é feita essa percepção da identidade feminina, Cisne (2015, p. 79) se baseia em Simone de Beauvoir (1980) com a frase:

[...] ninguém nasce mulher: torna-se mulher. Nenhum destino biológico, psíquico, econômico define a forma que a fêmea humana assume no seio da sociedade; é o conjunto da civilização que elabora esse produto intermediário entre o macho e o castrado que qualificam de feminino.

Essa reflexão influenciou o pensamento feminista desde o século XX e ainda nos faz pensar que as mulheres não nascem subordinadas aos homens; é a partir da introjeção da estrutura social em que vivemos que incorporamos o patriarcado como cultura dominante, "por isso, mulheres reproduzem o patriarcado independente da presença masculina e não porque gostam de ser submissas" (CISNE, 2015, p. 80). 
A autora salienta que é importante não aceitar a explicação de que as mulheres são submissas porque elas incorporam a submissão, mas sim questionar os motivos pelos quais elas incorporam essa submissão e de quem são os interesses por trás dessa condição. Isso nos leva a refletir que é preciso tirar a culpa das mulheres e entender a conjuntura que as levam a assimilar esse tipo de cultura dominante.

Pensando nessa perspectiva de que é necessário que as mulheres tomem consciência da sua submissão promovida pelo patriarcado, Pinto (2003) ressalta que, desde a Revolução Francesa, que ocorreu no século XVIII, foi possível identificar movimentos organizados por mulheres em busca do direito à cidadania. No início desse processo, percebeu-se que eram manifestações que poderiam ser mais ou menos organizadas.

Pinto (2003, p. 13) aponta que, no período entre a segunda metade do século XIX e as primeiras décadas do século XX, as manifestações deram "lugar a uma campanha mais orgânica pelos direitos políticos de votarem e serem votadas". Pela perspectiva da autora, o movimento sufragista que se espalhou tanto pela Europa quanto pelos Estados Unidos se configurou enquanto a primeira forma do feminismo organizado no mundo.

Ao voltar o nosso olhar para a situação do Brasil em meio a essas manifestações femininas, Pinto (2003) destaca que as primeiras movimentações ocorreram ainda no século XIX. O movimento feminista teve características muito peculiares, pois se dispunha a desafiar a ordem conservadora que afastava a mulher do espaço político, do direito à cidadania e, em alguns momentos, trazia um projeto revolucionário oriundo da luta do proletariado, que entendia a luta das mulheres como uma extensão da busca pela libertação.

Antes da separação em vertentes do feminismo no Brasil, Pinto (2003) registra que já havia manifestações de lutas de mulheres pelo direito de serem eleitoras e também candidatas. A autora nos apresenta a dentista gaúcha Isabel de Souza Matos, que, em 1881, requereu o direito ao voto por meio de uma lei que proporciona a possibilidade de votar a quem fosse portador de títulos científicos. Em sua cidade, ela se saiu vitoriosa, mas o seu direito foi suspenso em 1890, quando tentou se alistar no Rio de Janeiro. Outra manifestação de busca pelo direito de se manifestar na política foi a apresentação da Isabel Dilon como candidata à Constituinte, na Bahia, no século XIX, porém ela não conseguiu se alistar.

A historiadora nos mostra que a questão do direito ao voto para as mulheres já havia sido discutida na Constituinte republicana de 1891 e, ainda, contava com apoiadores como os políticos 
Epitácio Pessoa, Hermes da Fonseca e Nilo Peçanha, que posteriormente se tornaram presidentes da República. A inclusão da mulher como eleitora não foi aceita, porém a Constituição também não proibiu o voto delas. Pinto (2003) traz que esse fato da Constituição não foi um mero esquecimento; para ela, a mulher não foi mencionada porque elas não existiam como sujeitos dotados de direitos para os constituintes. Segundo a autora a exclusão era algo comum da época e, por isso, elas nem eram mencionadas. Nessa perspectiva, o fato de as mulheres não serem apontadas na Constituição de 1891 nem mesmo como sujeitos proibidos de votar era apenas uma materialização da exclusão e da não consideração delas enquanto sujeitos dotados de direitos. Como elas nem mesmo eram citadas na lei, muitas delas solicitaram o alistamento durante os 40 anos em que essa versão da Constituição vigorou.

A República do Brasil nasceu de uma luta entre oligarquias rurais e o centralismo monárquico. O país era marcado por um federalismo que acabou de sair da escravatura e contava com uma grande população de pobres que não tinha tradição de valorizar o trabalho nem os valores igualitários. Pinto (2003) mostra que, em meio a essas condições, a construção de uma cidadania republicana não foi possível. Nesse contexto, o país foi regido pelas oligarquias do estado de Minas Gerais e São Paulo. O Brasil se organizou nesse sistema até a Revolução de 1930, que rompeu com esse pacto. Para a historiadora, o feminismo encontrou no interior da oligarquia uma possibilidade para emergir. Nesses núcleos familiares, foi possível encontrar famílias com cultura e com posses que criavam filhos eruditos e que alcançavam o Ensino Superior.

Praticamente sem exceção, é dentro desses núcleos familiares diferenciados que surgiam as principais vozes femininas contrárias à opressão da mulher. Não havia nessas condutas éticas diversas ou formas alternativas de pensar o papel da mulher, mas um ambiente distinto que possibilitou às filhas o acesso ao mundo culto da leitura e da valorização da educação (PINTO, 2003, p. 17).

A autora nos mostra que o sistema que governava o país era rígido, mas é dentro das próprias famílias que as mudanças começam a acontecer, como o acesso das mulheres à educação. Outro ponto importante desse contexto é que foi a partir da década de 1910 que houve o surgimento da cultura urbana no Brasil, que tinha a classe média e a operária como principais expoentes. E essa mistura provocada pelo contato urbano permitiu o aparecimento de organizações sociais, como a busca das mulheres por direitos. 
No período entre a mudança do século XIX para o XX e até 1932, Pinto (2003) aponta que houve três tendências femininas no território brasileiro. A primeira vertente é chamada pela autora de feminismo bem-comportado, a segunda é o feminismo difuso e a terceira é apresentado como o feminismo malcomportado.

A primeira fase do feminismo no Brasil teve como ponto de partida a luta das mulheres por direitos políticos, por meio da participação eleitoral no papel de eleitoras e candidatas. O Partido Republicano Feminino foi fundado em 1910 por um grupo de mulheres que estavam inconformadas com a não aprovação do voto feminino pela Constituinte. Pinto (2003) chama a atenção por ser um fato excepcional, pois um partido político é formado por um grupo de pessoas que propõe à sociedade um programa para chegar ao governo por meio das eleições. Nessa perspectiva, é significativo ver que mulheres estão tomando essa posição, pois elas não têm direitos políticos e mesmo assim criam um partido para representar os interesses femininos na esfera política. Fundado pela professora Leolinda Daltro e a poetisa Gilka Machado, defendia o direito ao voto, a emancipação e a independência feminina.

Daltro e Machado participavam de eventos e faziam uso dos meios de comunicação para colocar na imprensa do Rio de Janeiro a questão do voto. Além disso, elas realizaram uma marcha com 90 mulheres em 1917, que se mostrou significativa, pois naquele período as mulheres não podiam transitar nas ruas sozinhas. O partido desapareceu no final da década de 1910, que foi na mesma época que Bertha Lutz retornou de Paris. Pinto (2003) traz o nome de Lutz como uma figura que se destacou nessa primeira onda de feminismo no território brasileiro, durante a década de 1920 até 1970.

Lutz fundou a Federação Brasileira para o Progresso Feminino (FBPF) após um período de estudos na capital francesa. A bióloga era filha de uma enfermeira inglesa e de um cientista brasileiro. Este arranjo familiar fez com que ela pertencesse às elites econômica e intelectual. Após se formar na Universidade de Sorbonne, Lutz tornou-se a bióloga do Museu Nacional e formou-se em direito em 1934. A historiadora descreve que a formação no exterior, a atuação profissional e ser uma cientista no serviço público permitiram que Lutz tivesse as condições para ter a posição de liderança frente à fundação.

A FBPF tinha como principal luta o direito ao voto feminino e essa manifestação ecoou entre os políticos daquele período, que resultou na aliança entre o senador e depois governador do estado do Rio Grande do Norte Juvenal Lamartine e Bertha Lutz. Pinto (2003, p. 25) destaca que 
“evidentemente, essas mulheres também desafiaram os moldes de sua época, escreveram e se expuseram publicamente, mas é importante enfatizar o caráter altamente elitista do grupo que se poderia chamar de 'núcleo duro' da FBPF". Por mais que elas se destaquem na luta pelo direito das mulheres, elas ainda faziam parte da elite brasileira.

A autora reflete que a luta das mulheres que possuíam cultura e pertenciam às classes dominantes era em torno do voto não somente porque era a pauta que estava sendo discutida nos países centrais, mas também porque elas tinham o respaldo dos outros membros da elite conservadora e da classe política brasileira. Nesse sentido, Pinto (2003) denomina como feminismo bem-comportado, pois ele atuava no limite das classes e não questionava a organização das relações patriarcais.

\begin{abstract}
Não se tratava unicamente de mulheres com ideias estranhas para sua época ou apenas excepcionais, pela cultura ou pela coragem. Poderiam até ser tudo isso, mas um novo espírito de época, do qual eram o mesmo tempo frutos e construtoras, começava a tomar forma nas cidades, por meio de movimentos de opinião que buscavam alastrar a participação política por intermédio da inclusão de setores que dela haviam sido alijadas pelas oligárquicas (PINTO, 2003, p. 28).
\end{abstract}

Outra disputa que era possível encontrar naquele período era a da liberdade de informação. Pinto (2003) aponta que essa disputa era uma constante entre os sujeitos que tinham como objetivo fazer mudanças no regime político ou na organização hierárquica e excludente que existia entre as pessoas. A autora mostra que ter uma opinião independente e formada a partir do conhecimento dos fatos parece ter sido um dos grandes mitos sobre a liberdade daquele período, pois segundo ela, a Constituição de 1824 ainda excluía as pessoas que não tinham liberdade para formar opiniões. E, com a instauração da República, a imprensa livre era tida como uma base para a democracia verdadeira.

Percebemos que os meios de comunicação são entendidos como pontos necessários para que haja mudança nas estruturas organizadoras da sociedade, pois, ao difundir informação, eles oferecem subsídios para que os indivíduos formem as suas próprias opiniões. Conforme afirma a autora, "nesse ambiente, qualquer grupo com pretensão de se apresentar à sociedade com novas ideias buscava a imprensa para se expressar e formar uma opinião pública a seu favor. Evidentemente isso ocorria no Brasil nos limites estritos de uma classe média urbana e culta" (PINTO, 2003, p. 29); assim, o recorte ainda ficava restrito às camadas mais elevadas da sociedade urbana. 
As feministas também fizeram dos meios de comunicação um espaço para divulgar as suas ideias e a propaganda foi a estratégia escolhida para isso. Pinto (2003) afirma que elas buscavam formar um movimento que tivesse opinião a favor da libertação e comenta que esse movimento feminista se diferenciou do de Bertha Lutz, pois ele se dirigia às mulheres e não aos detentores do poder. A autora chama essa segunda vertente de feminismo difuso, que se expressa por meio da imprensa feminista alternativa. As mulheres que compunham esse movimento eram cultas, tinham uma vida pública e atuavam, em sua maioria, como professoras, escritoras e jornalistas.

As atividades de mulheres feministas em jornais foram bastantes expressivas e espalharam-se pelo país, pois na época, além dos jornais que circulavam nas capitais, havia um número incontrolável de pequenos jornais, tanto de interesse geral como de associações, sindicatos, grêmios literários ou que tratavam de assuntos específicos (PINTO, 2003, p. 30-31).

A autora chama a atenção para o fato de a grande maioria da população viver no campo e ainda ser analfabeta, e esse número de pessoas que não sabiam ler era ainda maior entre as mulheres. Mesmo assim, foi necessária a existência de diferentes jornais, com tamanhos e alcances diferentes, para divulgar notícias e construir a opinião dos outros. Outro ponto importante de se pensar nesse período era que não havia muitos meios de comunicação de massa e, por isso, a mensagem que era escrita se tornava a única forma de divulgar informação.

Pinto (2003) recorre à pesquisadora de imprensa feminista no Brasil Dulcília Buitoni para falar desse recorte histórico. Buitoni (1981 apud PINTO, 2003) afirma que as primeiras publicações feitas por mulheres datavam do início do século XIX e abordavam questões quase que exclusivamente sobre moda, mas esse quadro se alterou e temas como política, literatura e cultura começaram a aparecer. Um exemplo dessa trajetória foi Francisca Senhorinha Motta Diniz, que possivelmente foi a primeira mulher fundadora de um jornal, que tinha como objetivo divulgar a causa das mulheres, como a preocupação com o voto, a luta pelos direitos e os direitos civis. $\mathrm{O}$ periódico foi fundado em 1872, em Minas Gerais, com o nome de $O$ Sexo Feminino. Dois anos depois da sua fundação, o jornal foi transferido para o Rio de Janeiro e teve seu nome alterado para 15 de Novembro do Sexo Feminino, após a proclamação da República. Pinto (2003) destaca que Francisca afirmava a necessidade das mulheres estarem cientes dos seus direitos para não serem enganadas e que elas precisavam da educação para conseguir a emancipação. Outro exemplo de jornal da época foi editado por Josephine Álvares de Azevedo, que era irmã do poeta Álvares de 
Azevedo. O periódico tinha o nome de A Família e foi produzido em São Paulo entre 1888 e 1897. A sua mensagem carregava a necessidade da educação das mulheres como forma de libertação.

A autora destaca que as mulheres que fundaram e realizavam a publicação dos jornais eram de famílias com uma cultura acima da média do país e tinham estudado no exterior. As matérias abordavam temas mais delicados para aquele período, como sexualidade e o divórcio, e isso mostra uma versão menos comportada do feminismo no Brasil no início do século XX. Pinto (2003) comenta que essa manifestação está apenas em um pequeno espaço da sociedade e que não eram preocupações das elites políticas e culturais daquele período. No entanto, perceber que esses movimentos já estavam acontecendo demonstra a tomada de consciência de alguns sujeitos da existência dessas pessoas que estavam excluídas da esfera política.

A terceira linha do feminismo apresentada por Pinto (2003) era a anarquista, a qual ela denominou como sendo o malcomportado. Essa perspectiva teve como principal influência os imigrantes, principalmente os italianos e, em menor quantidade, os portugueses e espanhóis, que chegaram ao Brasil nas primeiras décadas do século XX e trouxeram os ideais libertários do anarquismo. Pinto (2003, p. 33) relembra que “o ideário anarquista esteve presente com impetuosidade nas primeiras grandes greves operárias no Brasil e contribuiu para radicalizar o debate sobre as questões de exploração do trabalho pelos capitalistas". No entanto, essa influência do anarquismo é um paradoxo, pois foi necessário um espaço revolucionário não feminista para se perceber as contradições em relação às condições da exploração da mulher devido às relações de gênero.

Esse movimento se difere das sufragistas, pois elas apontam a opressão masculina. Segundo a autora, o manifesto dessas mulheres apresenta que não é possível chegar à igualdade sem que seja feito o reconhecimento da desigualdade da mulher na fábrica.

Essas mulheres, no início do século XX, anteciparam uma luta que só ganha espaço e legitimidade no fim do século XX, a do reconhecimento da especificidade da opressão, isto é, que os oprimidos não são oprimidos da mesma forma. Que ser mulher, ser negro ou pertencer a qualquer outra minoria traz uma carga a mais em relação a ser homem e branco. Essas anarquistas, na contramão dos movimentos libertários da época, chamavam a atenção para as diferenças (PINTO, 2003, p. 35).

Pinto (2003) chama a atenção para o fato de esse feminismo ter antecipado a questão das diferenças sociais, raça e classe. Uma das grandes expoentes nessa perspectiva era Maria Moura, 
que apresentava o homem como sendo opressor e, no capitalismo, assume o papel do patrão que explora as mulheres. As integrantes desse movimento defendem que a libertação seja feita de forma radical e o grupo era composto de mulheres trabalhadoras e intelectuais.

Ao final dessa reflexão das primeiras manifestações do feminismo no Brasil, percebemos como as mulheres passaram a tomar consciência da sua submissão para iniciar as mudanças dentro da sociedade. Para Pinto (2003), o movimento das mulheres se parece com um exemplo das formas de como essas organizações poderiam ser e elas se mostram não apenas como um grupo que luta diante das instâncias do Estado para propor projetos que fossem de seu interesse, mas sim de uma estratégia mais complexa para a formação dessa instituição. Como forma de colocar suas pautas em destaque, elas usavam os jornais, apareciam em eventos públicos e realizavam passeatas para ampliar a sua base de apoio e criar uma opinião pública que fosse favorável ao movimento.

Marina Maluf e Maria Lúcia Mott (1998) afirmaram que as mudanças no comportamento feminino causaram incômodo nos conservadores e promoveram debates entre progressistas nas três primeiras décadas do século XX. Para as autoras, essas discussões foram causadas pela presença das moças das camadas médias e altas, que são de boa família, transitando pelas ruas da cidade com o objetivo de abastecer a casa e fazer tudo que fosse necessário.

Era possível perceber em alguns pontos a reivindicação para a igualdade dos sexos e Maluf e Mott (1998) chamam a atenção para as leituras das mulheres que são vítimas de preconceito, que vivem fechadas no lar, possuem uma existência monótona, sem conhecimento e ainda estão presas financeiramente aos maridos. Como exemplo, elas falam da Revista Feminina, que trazia temas e discussões sobre essas novas posturas adotadas pelas mulheres daquele período. Nessa perspectiva, a revista se tornava um espaço para que elas fizessem reivindicações como a igualdade para ambos os sexos e também era um meio para que elas tivessem acesso à informação.

\footnotetext{
Através de um processo diagnosticado por vários críticos temerosos como imperfeito e desorganizado, a nova paisagem urbana, embora ainda guardasse muito da tradição, era povoada por uma população nova e heterogênea, composta de imigrantes, de egressos da escravidão e de representantes das elites que se mudavam do campo para as cidades (MALUF; MOTT, 1998, p. 371).
}

Para as autoras, uma das características que permitiu que as mulheres tivessem acesso a essas novas ideias foi a vivência na cidade, onde havia a possibilidade de contato com pessoas de diferentes classes, imigrantes e ex-escravos. Maluf e Mott (1998) refletem que diversos intelectuais 
consideram essas experiências e linguagens nas cidades como as responsáveis pelo desgaste que a ordem social sofreu, com a mudança nos costumes, alterações nas rotinas das mulheres e na relação entre elas e os homens, que são mudanças que Pinto (2003) também percebeu ao refletir sobre os movimentos feministas brasileiros no mesmo período.

As autoras destacam que, nas primeiras décadas do século XX, os deveres das mulheres foram traçados com base no discurso ideológico dos conservadores e das matizes reformistas, o que resultou na desumanização delas enquanto sujeitos históricos e definiu os comportamentos e os papéis sociais. Isso contribuiu para promover a construção e difusão das representações do comportamento feminino e foi feito até que elas fossem colocadas no espaço de "rainha do lar". Segundo Maluf e Mott (1998, p. 373-374), existe a crença de que as mulheres são biologicamente feitas para realizar as atividades da esfera privada; “[...] o discurso é bastante conhecido: o lugar da mulher é o lar, e sua função consiste em casar, gerar filhos para a pátria e plasmar o caráter dos cidadãos de amanhã". Nessa perspectiva, as historiadoras comentam que as mulheres não tinham como se realizar fora do lar e, seguindo a mesma lógica, os homens também não tinham como alcançar o sucesso no lar, visto que eles deveriam ocupar a rua, o espaço público.

A leitura de revistas e jornais poderia ser uma forma de libertação para as mulheres, mas também poderiam ser instrumentos para reforçar essa destinação feminina. Maluf e Mott (1998) trazem como exemplo o manual de economia doméstica $O$ Lar Feliz, que foi publicado em $1916 \mathrm{e}$ era destinado às jovens mães e a todas as pessoas que amam seu lar. As autoras afirmam que o autor deste manual apresentava quais eram os papéis dos homens e das mulheres na sociedade e define essa organização como sendo um lar feliz.

É importante perceber que esse manual foi publicado no mesmo ano que o Código Civil de 1916, e as autoras chamam a atenção para os preceitos desta norma que colocava a mulher casada como inferior ao marido.

\footnotetext{
Ao homem, chefe da sociedade conjugal, cabia a representação legal da família, a administração dos bens comuns do casal e dos particulares da esposa segundo o regime matrimonial adotado, o direito de fixar e mudar o local de domicílio da família. Ou seja, a nova ordem judiciária incorporava e legalizava o modelo que concebia a mulher como dependente e subordinada ao homem, e este como senhor da ação (MALUF; MOTT, 1998, p. 375).
}

Com base no que foi apresentado pelas autoras, percebemos que a lei legitimava a submissão da mulher perante ao marido. Nesse sentido, o que conferia ao marido o poder dentro 
do âmbito familiar e o colocava como responsável por realizar a manutenção, proteção e assistência era o trabalho. A participação das mulheres na imprensa da época foi responsável por divulgar algumas reflexões sobre os motivos pelos quais as elas começaram a ir para a rua. As autoras apresentam como exemplo o editorial de outubro de 1918 da Revista Feminina, em que Ana Rita Malheiros atribui a culpa ao homem moderno pela responsabilidade do avanço do feminismo. Para Malheiros, o homem era "quase inválido" e, ao ser incapaz de produzir o suficiente para o sustento do lar, fez com que as mulheres tivessem que sair para trabalhar quando elas prefeririam, na verdade, ficar no conforto do lar.

Com as mudanças nas quais os membros dessa sociedade estavam inseridos, algumas acusações e reclamações levavam à necessidade de modificar o casamento como forma de reforçálo como instituição social. No entanto, mesmo com essa consciência da necessidade de remodelar o casamento, as autoras afirmam que ele está longe de entrar em colapso. Além disso, os conservadores daquele período percebiam qualquer flexibilização na divisão sexual dentro das famílias como uma ameaça modernizante.

As inovações trazidas pela tal "vida moderna" povoavam as páginas dos mais diferentes tipos de literatura, o que por si só indicava um forte movimento em prol da defesa de determinadas instituições basilares da sociedade, mesmo que para isso fosse necessário acatar mudanças e introduzir outras. Nada, entretanto, que pudesse ferir a legitimidade das regras do sistema familiar e social (MALUF; MOTT, 1998, p. 385).

Na passagem apresentada pelas autoras, percebemos que essa influência da modernidade adivinha do contato que as pessoas tiveram com o material escrito da época. Contudo, essas reflexões que Pinto (2003) e Maluf e Mott (1998) abordam que eram trazidas nas revistas e jornais que circulavam acabaram por inserir as discussões sobre como entender o lugar do homem e da mulher na sociedade das primeiras décadas do século XX. Com a percepção de mudanças em nosso contexto, os promotores da moral e da ordem, como Maluf e Mott (1998) denominam, apresentaram como ilícita qualquer relação entre homens e mulheres que fosse firmada fora do matrimônio. A intenção é mostrar que não existia felicidade fora dos laços matrimoniais.

Em meio à estabilidade proposta pelo ambiente urbano e as possíveis mudanças que eles pudessem trazer para o nosso contexto, a intenção dos conservadores era reforçar a imagem da mulher como uma esposa virtuosa - "prescreveu-se para ela complacência e bondade, para prever e satisfazer os desejos do marido sequer expressos; dedicação, para compartilhar abnegadamente 
com o cônjuge os deveres que o casamento encerra; paciência para aceitar as fraquezas de caráter cônjuge" (MALUF; MOTT, 1998, p. 390). O que ameaçava a virtuosidade das esposas eram as moças da modernidade, que eram cheias de liberdade, vestiam saias curtas e colantes e ficavam de abraços e beijos com os homens. Em meio às mudanças no convívio de costumes e tradição que a vida urbana permite, as autoras ressaltam que a imprensa destacava a importância da educação para que as mulheres se tornassem modernas.

É importante considerar que o acesso à informação, aos bens de consumo e até mesmo à educação era restrita a uma camada específica da população brasileira, como Pinto (2003) e Perrot (2007) já haviam exposto. O recorte de classe social acaba sendo muito pertinente nesta análise, pois percebemos também quais eram as mulheres que eram influenciadas pelos movimentos feministas da época.

Apesar do desejo de muitos intelectuais e profissionais das camadas dominantes de espelhar homens e mulheres brasileiros pelas imagens da burguesia das duas maiores cidades do período - as capitais do progresso, Rio de Janeiro e São Paulo -, essa não era a realidade vivida pela grande maioria dos brasileiros. Os padrões de consumo foram absorvidos de forma desigual pelas diferentes regiões e cidades e pelas diferentes camadas da população (MALUF; MOTT, 1998, p. 400).

As autoras ressaltam que no século $\mathrm{XX}$ ainda era possível encontrar mulheres que realizavam os serviços domésticos, cuidavam dos filhos e tinham as atividades fora de casa para prover o sustento da família. As autoras ainda ressaltam que a modernização e o desenvolvimento industrial e urbano promoveram o maior acesso à escolaridade. Além disso, com a divulgação feita pela imprensa de que mais mulheres estavam atuando no espaço público no pós-Primeira Guerra, o progresso do feminismo e a contestação feminina por oportunidades de emprego permitiram que mais trabalhos fossem abertos para as brasileiras fora do lar, como destacam as historiadoras. As mulheres que trabalhavam fora de casa, no entanto, eram vistas com certa desconfiança, pois era necessário que elas fossem boas donas de casa independente de qual fosse a sua profíssão.

Maluf e Mott (1998) identificam que, em 1915, a Dra. Emma Drake publicou um artigo que abordava a temática da educação materna, que as mulheres não compreendem que a tarefa do lar não termina quando os filhos estão nutridos, vestidos e seguros. As mães ainda têm que preparar os filhos e filhas para serem os homens e mulheres de amanhã. 
[...] as ciências naturais, a higiene, a física, a química, a astronomia, a matemática, a geografia, as artes, as indústrias, tudo, representa uma necessidade real! A mestra deve ser a Mãe, e é preciso que a mulher tenha uma soma grande de conhecimentos, para não perder uma interrogação do filho (MALUF; MOTT, 1998, p. 402-403).

Percebemos que quando é para trabalhar fora de casa e estudar como forma de realização pessoal, as mulheres são vistas com maus olhos. No entanto, quando é para satisfazer as dúvidas dos filhos no que concerne a sua formação, as mulheres precisam estar dispostas a fazê-lo.

Para as autoras, quando se solidificam os complexos conjuntos de atividades e experiências de vida em determinados papéis sociais, os valores morais são enfraquecidos e novas configurações são constituídas. Com base nesse entendimento de formação e solidificação de valores, as famílias enquanto "lar feliz" se tornaram o espaço onde as mulheres são as rainhas do lar, escondendo os conflitos e as relações de poder que existem no seu interior, "atribuindo-se às mulheres, sobretudo, às casadas uma importância social como forma de indenização, já que as portas de acesso à igualdade de direitos com os homens foram cuidadosamente fechadas" (MALUF; MOTT, 1998, p. 421).

Em correspondência ao período da segunda onda de feminismo no mundo, o Brasil da década de 1960 teve uma mudança diferente dos outros países. Pinto (2010, p. 16) afirma que "o país, nos primeiros anos da década, teve grande efervescência: a música revolucionava-se com a Bossa Nova, Jânio Quadros, após uma vitória avassaladora, renunciava, Jango chegava ao poder, aceitando o parlamentarismo, a fim de evitar um golpe de estado".

Em 1963, a população começou a perceber a radicalização. Pinto (2010) ressalta que havia, de um lado, os partidos de esquerda, estudantes e o governo e, do outro, os militares, governo dos Estados Unidos e uma classe média que estava assustada. Em 1964 aconteceu o golpe militar e, em 1968, essa tomada de poder se instituiu em uma ditadura mais repressiva "por meio do Ato Institucional n. ${ }^{\circ} 5$ (AI-5), que transformava o Presidente da República em um ditador" (PINTO, 2010, p. 16).

A autora ressalta que, em meio a essa configuração de ditadura, as manifestações feministas começaram no Brasil na década de 1970. "O regime militar via com grande desconfiança qualquer manifestação de feministas, por entendê-las como política e moralmente perigosas" (PINTO, 2010, p. 16-17). Em 1975, na I Conferência Internacional da Mulher, realizada no México, a Organização das Nações Unidas (ONU) declarou que os próximos 10 anos seriam a década da mulher. No Brasil, debates que tiveram como título "O papel e o comportamento da mulher na realidade brasileira" 
foram realizados também em 1975 e contaram com o patrocínio do Centro de Informações da ONU. Outra manifestação abordada por Pinto (2010) foi que, em 1975, Terezinha Zerbini (assistente social, advogada e ativista de direitos humanos) lançou o Movimento Feminino pela Anistia, que teve muita importância na luta pela anistia de 1979.

Por outro lado, as brasileiras que estavam exiladas começaram a ter contato com o feminismo, principalmente o europeu. No entanto, Pinto (2010) comenta que os homens exilados viam com certa desconfiança a luta pelo feminismo, pois eles acreditavam que essa pauta poderia desviar o foco da luta contra a ditadura e do socialismo.

Na década de 1980, o Brasil passou pelo movimento de redemocratização e o feminismo vivenciou agitação da luta dos direitos das mulheres, que se manifestam em grupos e coletivos que abordam os temas "violência, sexualidade, direito ao trabalho, igualdade no casamento, direito à terra, direito à saúde materno-infantil, luta contra o racismo, opções sexuais" (PINTO, 2010, p. 17). A autora ressalta que, apesar de o movimento feminista ter origem na classe médica que era intelectualizada, realizou a interface com as camadas que eram as mais populares e isso permitiu que houvesse discursos e ações de ambos os lados.

\subsection{A MULHER NO SÉCULO XXI: O BRASIL CONTEMPORÂNEO}

Pinto (2003) afirma que o movimento feminista não acabou no final da década de 1990 e início dos anos 2000, mas ele acabou se esmaecendo e houve algumas manifestações antifeministas ou pós-feministas. A autora chama a atenção que, no início do século XXI, novas formas de pensamento e do próprio movimento surgiram. Assim, em primeiro lugar, houve a organização do movimento feminino e, em segundo, a profissionalização do movimento com o surgimento de Organizações Não Governamentais (ONGs) que tinham como foco a questão das mulheres. Pinto (2003, p. 91) comenta que "essas duas movimentações são complementares e, ao mesmo tempo, agem em direções diversas".

Para a autora, o que aconteceu foi a generalização do pensamento feminista e a especialização do movimento, que aconteceu por meio das ONGs. Nessa perspectiva, ela destaca que foi na década de 1990 que as demandas dos movimentos sociais começaram a ser incorporadas no discurso público. Pinto (2003) afirma que esse movimento aconteceu em países do hemisfério Norte e também no Brasil e a mudança de algumas posturas, proposta por movimentos identitários 
e em especial o feminismo, resultou em alguns sinais mais singelos, como "a diminuição do espaço de legitimidade para piadas e anedotas racistas, machistas e que ridicularizam o homossexual, principalmente o masculino" (PINTO, 2003, p. 92).

Outra mudança apontada pela autora é a não-legitimidade de discriminar os trabalhadores por causa do sexo; um avanço muito relevante nas relações de trabalho. Pinto (2003) explica que, mesmo com essas mudanças, a discriminação ainda existia, mas não era mais legítimo manter políticas internas de empresas e órgãos públicos e ainda existia a possibilidade de fazer reclamações legais.

A autora chama a atenção para o fato de que, na década de 1990, houve um aumento no espaço dedicado às questões relacionadas ao direito das mulheres em campanhas eleitorais. Para ela, é interessante perceber que as propostas dedicadas a esse público poderiam ser encontradas tanto em campanhas para presidência para a República quanto nas dos candidatos a vereador. Pinto (2003) comenta que a importância que se dá a essas pautas não está na sinceridade ou comprometimento das causas defendidas, mas na percepção de que essa temática pode gerar votos e isso veio da militância organizada que lutava pelo direito das mulheres nas campanhas eleitorais. As autoras Denyse Pontes e Patrícia Damasceno (2017) destacam que os movimentos feministas tiveram um papel muito importante enquanto sujeitos políticos nas décadas de 1980 e 1990. Esses grupos propuseram e articularam políticas públicas relacionadas aos direitos das mulheres e às questões de gênero em áreas como a da saúde, educação, assistência social e trabalho.

Mesmo com essa importância de representar as pautas relevantes para as mulheres na política nacional, Pinto (2003) considera sua participação na política "raquítica". A autora comenta que só com a lei que garante $30 \%{ }^{5}$ de mulheres nas listas partidárias para os cargos legislativos podemos ver mudanças nesse quadro. A autora ainda aponta para a dificuldade de preencher esses números e, quando eles são completados, muitas das candidatas são fantasmas e não desejam se eleger. No entanto, não é possível reduzir a participação da mulher na política apenas com base nessas conquistas. Pinto (2003, p. 95) aponta que é necessário perceber ações anteriores, como:

[...] a criação de um Conselho Nacional da Condição da Mulher em 1985, que teve atuação fundamental na segunda metade da década de 1980, principalmente junto à Assembléia Nacional Constituinte; a própria Constituição de 1988, que assegurou um conjunto importantíssimo de direito às mulheres; a existência no

\footnotetext{
5 Lei n. ${ }^{\circ}$ 9.504, de 30 de setembro 1997, que estabelece normas para as eleições. Disponível em: http://www.planalto.gov.br/ccivil_03/leis/L9504.htm. Acesso em: 27 abr. 2020.
} 
âmbito do Ministério da Saúde do PAISM; a multiplicação pelo país de delegacias de política da mulher e conselhos estaduais e municipais.

Para a autora isso representa a firme participação das mulheres na defesa dos seus interesses. Além dessa busca pela representatividade feminina, outra bandeira levantada pelo movimento é a da luta contra a violência que faz da mulher a vítima. Como medida para combater essa agressão, Pinto (2010, p. 17) salienta que existem Delegacias Especiais da Mulher espalhadas pelo país e, entre a sua maior conquista, está a "Lei Maria da Penha (Lei n. ${ }^{\circ} 11$ 340, de 7 de agosto de 2006), que criou mecanismos para coibir a violência doméstica e familiar contra a mulher".

Mesmo com a conquista do voto e da participação na vida política e no mercado de trabalho, percebemos que os lugares que as mulheres e os homens ocupam na sociedade ainda são diferentes. Com base na pesquisa do $\mathrm{IBGE}^{6}$ realizada entre 2012 e 2018, a presença da mulher ainda é menor. Por meio dos dados, vê-se que não houve mudança estrutural entre os anos de 2012 e 2017, sendo que a atuação do homem na política permanece maior do que a das mulheres. A pesquisa aponta que a participação na ocupação dos homens chegou a 56,3\% em 2018, e a das mulheres correspondia a $43,7 \%$.

Pontes e Damasceno (2017) apontam para as mudanças que os governos Lula (2003-2010) e Dilma Roussef (2011-2016) trouxeram para o Brasil. Em 2003, a Secretaria de Políticas para as Mulheres (SPM) foi criada. Em 2004, a I Conferência Nacional de Políticas para as Mulheres foi realizada por meio da SPM e as diretrizes discutidas nas conferências entre 2007 e 2013 resultaram no Plano Nacional de Políticas para as Mulheres. Em 2004, também foi criada a Secretaria de Educação Continuada, Alfabetização e Diversidade, que se tornou a Secretaria de Educação Continuada, Alfabetização, Diversidade e Inclusão (Secadi) em 2011. Para as autoras, a criação da Coordenação Geral da Diversidade, em 2012, pela SPM foi um marco para a política das mulheres, pois "pretende-se, assim, garantir políticas que contemplem as especificidades e diferenças das mulheres, promovendo o combate à discriminação e aos preconceitos" (PONTES; DAMASCENO, 2017, p. 06).

Já no governo de Dilma, Pontes e Damasceno (2017) destacam a definição das Secretarias de Políticas do Trabalho e Autonomia Econômica das Mulheres; enfrentamento à Violência contra

\footnotetext{
${ }^{6}$ Dados retirados da Pesquisa Nacional por Amostra de Domicílio Contínua (PNAD Contínua) e divulgada pelo IBGE. Disponível em < https://biblioteca.ibge.gov.br/visualizacao/livros/liv101694_informativo.pdf> $>$. Acesso em 28 de abril de 2020 .
} 
as Mulheres; e Articulação Institucional e Ações Temáticas, que comporiam a SPM.

No ano de 2016, após o impeachment da presidente Dilma, o seu vice- Michel Temer toma posse como presidente do Brasil. No dia 18 de abril desse mesmo ano, a revista Veja publica a matéria intitulada Marcela Temer: bela, recatada e "do lar" para se referir à esposa do vicepresidente que iria tomar posse como chefe do Executivo do Brasil. A matéria retrata os modos da Marcela, como sendo a esposa zelosa, que usa vestido nos joelhos, fica em casa tomando cuidado o marido e do filho, é discreta e isso é uma sorte para o Michel Temer, como conclui a matéria.

No dia três de janeiro de 2019, a matéria publicada g1 e intitulada de "Em vídeo, Damares diz que 'nova era' começou: 'meninos vestem azul e meninas vestem rosa" ", ministra da Mulher, Família e Direitos Humanos, Damares Alves do atual governo. Para a ministra, essa nova era diz respeito a separação de gêneros e deixa em evidência o conservadorismo e reforça os valores tradicionais aos quais as mulheres são colocadas. Dessa forma, a cor rosa representa a feminilidade e o azul, retrata a masculinidade. E isso faz parte da construção social na qual estamos sendo inseridos e que representa o que se espera de quem nasce do sexo feminino e masculino

\footnotetext{
${ }^{7}$ Matéria disponível em: https://veja.abril.com.br/brasil/marcela-temer-bela-recatada-e-do-lar/. Acesso em: 14 mar. 2021.

${ }^{8}$ Matéria disponível em: < https://g1.globo.com/politica/noticia/2019/01/03/em-video-damares-alves-diz-que-novaera-comecou-no-brasil-meninos-vestem-azul-e-meninas-vestem-rosa.ghtml >. Acesso em 22 de mar. De 2021.
} 


\section{AS TELENOVELAS E A REPRESENTAÇÃO SOCIAL}

Como podemos perceber com as contribuições de Maluf e Mott (1998), Perrot (2007) e Pinto (2003), os meios de comunicação têm um papel importante na difusão do pensamento feminista ao longo da história das mulheres. Poder se comunicar e ter acesso aos meios de comunicação permite que as suas ideias cheguem ao maior número de pessoas. É por meio dos jornais e revistas do início do século XX que elas encontram espaço para levar as suas reivindicações para outras mulheres. Maluf e Mott (1998) nos trazem exemplos de artigos nos quais mulheres tomam o protagonismo e comentam sobre a situação da mulher neste mesmo século.

Pinto (2003) comenta casos de mulheres que também fizeram o uso da imprensa para publicar artigos sobre questões relacionadas ao feminismo e que buscaram se fazer presentes em eventos para que os jornais publicassem os seus nomes como forma de adquirir visibilidade para as manifestações da segunda onda. Trazendo para o contexto atual e pensando na condição que os meios de comunicação têm de realizar a construção social da realidade, podemos refletir sobre a possibilidade de as telenovelas entrarem nesse espaço de promoção de identidade.

As telenovelas se configuram enquanto produtos da cultura midiática dentro da sociedade brasileira. Como tal, contribuem para a formação de padrões a serem seguidos do que é ser homem ou mulher, família, trabalho, relações e do que é ser bem sucedido ou não. Além dessa oferta de modelos audiovisuais, essas representações apresentadas na mídia também auxiliam na construção de grupos, o "nós" e o “eles". Douglas Kellner (2001, p. 09) ressalta que "a cultura veiculada pela mídia fornece o material que cria as identidades pelas quais os indivíduos se inserem nas sociedades tecnocapitalistas contemporâneas, produzindo uma nova forma de cultura global”.

Entender essas representações também é uma forma de perceber como a sociedade está sendo organizada naquele contexto e como a mídia pode ser uma fomentadora dessas características que formam as identidades das sociedades. Nesse sentido, as telenovelas se tornam um objeto comunicacional para entender quais são essas personalidades que vêm se formando no Brasil ao longo desses últimos anos, desde a década de 1950, com a implantação da televisão.

Os modelos de homem e mulher, de namoro e casamento, organização familiar, divulgados pela novela e sucessivamente atualizados, amplificam para todo o território nacional as angústias privadas das famílias de classe média urbana do Rio de Janeiro e São Paulo. A novela estabelece padrões com os quais os telespectadores não necessariamente concordam mas que servem como referência 
legítima para que eles se posicionem. A telenovela dá visibilidade a certos assuntos, comportamentos, produtos e não a outros; ela define uma certa pauta que regula as interseções entre a vida pública e a vida privada (HAMBURGUER, 1998, p. 443).

Pensando nas telenovelas enquanto construtoras da identidade nacional e das representações do que é o outro, elas se tornam um importante objeto comunicacional para que possamos entender como a sociedade brasileira percebe as suas representações. Nesse sentido, buscamos compreender de onde veio essa representação das mulheres e como a telenovela Orgulho e Paixão pode contribuir para a construção da identidade feminina e abordar a temática feminista.

\subsection{ANALISANDO A HISTÓRIA DA TELENOVELA NO BRASIL}

O folhetim foi criado no século XIX, na França, e surgiu em um momento de transformação da sociedade francesa. Renato Ortiz (1989, p. 11) retoma a seguinte frase de Nettement (1966) que define que "o folhetim nada mais é do que um teatro móvel que vai buscar os espectadores em vez de esperá-los”. A lógica do folhetim acontece em um momento em que há uma mudança na questão mercadológica na França, e Ortiz (1989) destaca que, nesse mesmo século, há o surgimento de uma esfera de bens ampliados, o que cria um ambiente ideal para que a "cultura de mercado" comece a se expandir. Nesse sentido, a separação entre o que é cultura popular e de elite é desfeita e uma nova forma de consumir é formada nesse contexto, dando origem à cultura popular de massa.

Um detalhe relevante para que os folhetins ganhem notoriedade no país são as inovações tecnológicas que permitiram a impressão de livros e jornais. Ortiz (1989) lembra que, com o passar dos anos, no século XIX, os equipamentos relacionados à comunicação foram aprimorados, como a prensa rotativa, ilustração fotográfica, linotipo e a ampliação da estrutura comunicacional e das estradas de ferro, que mudaram a forma com as próprias pessoas se relacionavam com a comunicação. Com esses mecanismos, foi possível aumentar as possibilidades de difundir esses produtos impressos, o que está ligado ao contexto francês e inglês. Ortiz (1989) comenta que, na Inglaterra, surgiram os romances de estrada de ferro para promover uma distração durante as viagens e registra que "porém o impacto maior foi certamente o de, pela primeira vez, livros e jornais poderem ser enviados regularmente a locais mais distantes, o que significou muitas vezes a competição entre uma cultura popular urbana com outra, de caráter rural” (ORTIZ, 1989, p. 13). 
Esta nova forma de difundir a comunicação por meio da escrita mostrou-se mais ágil e com maior capacidade de chegar ao público e promoveu a maior aptidão das pessoas à leitura. Ortiz (1989) apresenta que o número de pessoas alfabetizadas no período antigo, na França, chegou a $60 \%$ da população em 1860 e a $90 \%$ em 1890. Para o autor, isso aconteceu porque o Estado promoveu a educação das camadas mais populares no interior do país, e aprender a ler permitiu o aumento da tiragem de jornais e livros.

É nesse contexto que os folhetins surgem na França e se tornam um tipo de leitura mais popular. Dentro da estrutura do jornal, este gênero é colocado no rodapé, um espaço que é visualmente demarcado e determinado para o entretenimento dos leitores. O autor destaca que no início não era fácil acessar os folhetins, pois eles eram publicados nos jornais que eram adquiridos somente por meio de assinatura, sendo que apenas depois de um tempo eles passaram a ser vendidos nas ruas. "O folhetim se desenvolve no Brasil quase que simultaneamente ao seu surgimento na França. Em outubro de 1838, o Jornal do Comércio (RJ) publica Capitão Paulo de Alexandre Dumas, série que é iniciada em Paris, no Echo, somente alguns meses antes (setembro do mesmo ano)" (ORTIZ, 1989, p. 15). Essa aceitação do folhetim é apresentada por ele como um costume dos brasileiros de aceitar tudo que era importado da França sem qualquer problema.

Para o autor, a escrita no Brasil teve dificuldade para ser feita no formato de livro, pois as tiragens eram poucas e foi preciso encontrar uma forma mais rápida de realizar essa publicação e, por isso, transformar as obras em folhetim era uma estratégia de divulgar a literatura. Ele ainda ressalta que o que era publicado vinha das traduções das produções francesas e os folhetins ainda ficavam restritos às elites dominantes e escravocratas, visto que a maior parte da população era analfabeta.

Ortiz (1989) cita Laurence Hallewell (1985) para afirmar que a leitura folhetinesca foi publicada no Brasil desde cedo, mas essa moda não ultrapassou o século XIX e, em 1885, já era possível ver seu declínio. Segundo o autor, o folhetim deixou de ser moda sem nem ter sido popular devido à maior parte da população ser analfabeta e ao fato de que a radionovela surge na década de 1940 e rompe com essa tradição francesa.

Ele também destaca que o rádio começou a ser explorado enquanto um veículo para transmitir "estórias seriadas" (ORTIZ, 1989, p. 18) nos Estados Unidos. O autor afirma que existia uma disputa para verificar se as rádios estadunidenses deveriam ou não depender de publicidade, 
mas que, no final da década de 1920, essa situação é alterada e este meio se consolida enquanto uma estrutura industrial com base na publicidade.

É a partir desse contexto que, em 1940, os dez maiores programas de rádio nos Estados Unidos eram as soap-operas e que $92 \%$ dos patrocinadores eram dedicados a esse programa, segundo Ortiz (1989). O sucesso da rádio neste país da América do Norte vem da criação dos grandes monopólios radiofônicos que surgiram no final das décadas de 1920 e 1930, que foi quando o aparelho de rádio se tornou um bem de consumo popular. $\mathrm{O}$ autor também comenta que, no período da Grande Depressão, o rádio é a forma mais barata de entretenimento e a venda do aparelho cresceu entre 1930 e 1934.

De fato, o que ocorre nos Estados Unidos é que determinadas agências financeiras do rádio comercial, em particular firmas como Procter and Gamgle, ColgatePalmolive, Lever Brothers, começam a produzir as denominadas 'óperas de sabão' para vender seus produtos às donas-de-casa (ORTIZ, 1989, p. 19).

Ortiz (1989) ressalta que as empresas que patrocinavam as radionovelas sofreram com a recessão econômica e encontraram essa forma de divulgação como alternativa para atingir um maior número de pessoas por meio da produção day-time series para as mulheres no horário diurno, que era mais barato que o nobre. $\mathrm{O}$ autor compara as telenovelas aos folhetins e, de acordo com a estrutura dos dois gêneros, o folhetim se organiza de uma forma que a narrativa se divide em capítulos que anunciam o desfecho final, e as soap-operas se constituem enquanto uma comunidade de personagens que vivem diferentes dramas sem que haja realmente um fim.

A outra diferenciação apresentada por Ortiz (1989) tem a ver com a questão comercial das soap-operas e dos folhetins. As produções das soap-operas dependiam da sua capacidade de manter uma audiência a baixo custo e de ter uma narrativa de massa. Com base nos dados de uma pesquisa sobre audiência feita em 1932, o autor aponta estas como as produções americanas que têm como público-alvo específico as mulheres. Os resultados mostram que as mulheres têm maior influência quando a questão é a realização de compras e afazeres domésticos. Além disso, a pesquisa revelou que elas preferem programas de entretenimento ao invés de didáticos durante a realização dos trabalhos em casa. Ortiz (1989) relembra que elas se tornam alvo quando o assunto são as vendas de produtos de limpeza e alimentícios, e as soap-operas eram o meio ideal para chegar até elas. 
O autor recorre a Tania Modleski que entende as soap-operas como narrativas femininas que se desenvolveram a partir das novelas domésticas, um gênero literário do século XIX nos Estados Unidos e que apresentava as mulheres como o fator moral e ético de preservação do lar. Essa perspectiva entende a mulher como figura central no lar, uma consumidora em potencial, um ser que vive no universo feminino e que pode ser explorado por uma narrativa - "a soap-opera 'vende' e 'fala' para mulher” (ORTIZ, 1989, p. 22).

Ortiz (1989) evidencia que não se sabe ao certo onde surgiram as radionovelas latinoamericanas, mas acredita-se que elas tenham surgido em Cuba. Para ele, existem três razões para que o surgimento das radionovelas tenha sido em Cuba. A primeira é que o sistema radiofônico já estava consolidado no país; a segunda é a proximidade com grandes centros, como Miami; e a terceira é o interesse dos Estados Unidos em expandir as suas fronteiras.

Os interessados por rádio no país da América Central não tinham acesso à literatura especializada em espanhol e acabaram procurando referências vindas dos EUA. Com a influência estadunidense e o uso de suas técnicas, Cuba teve a implantação de uma grande rede de radiodifusão e com uma mão de obra técnica e artística especializada. É em meio a esse contexto que surgem as primeiras radionovelas, que também foram patrocinadas por fábricas de sabão cubanas na década de 1930. Gonzáles (1986, apud ORTIZ, 1989, p. 23) afirma que "Havana emerge assim como um polo de reprodução que durante muitos anos exporta artistas, diretores de rádio, e sobretudo livretos de radionovela para toda América Latina".

O autor faz um panorama que até meados de 1930, os programas de rádio de Cuba eram destinados a um público genérico. Posteriormente, eles começaram a focar o público feminino e toda a família. Com isso, os produtores se inspiram nas soap-operas e, depois, a tradição de programas radiofônicos cubanos se enraíza no melodrama, voltado a questões trágicas. Dessa forma, as tramas não focavam apenas em fazer os ouvintes chorarem e o tema que se destaca é o amor.

O autor volta a destacar que são as fábricas de sabão que determinam o tom no qual a narrativa será trabalhada e que as radionovelas surgem de uma "bricolagem de uma tradição literária e as necessidades econômicas do rádio comercial” (ORTIZ, 1989, p. 25). Segundo ele, esse é o formato que é difundido para os outros países da América Latina, com a instalação das empresas estadunidenses Colgate-Palmolive e Gessy-Lever. 


\subsection{AS RADIONOVELAS NO BRASIL: O INÍCIO TARDIO}

A radionovela é iniciada no Brasil em 1941, quando o programa A predestinada foi lançado na Rádio São Paulo e Em busca pela felicidade, na Rádio Nacional, conta Ortiz (1989). O autor recorre à tese de Zenilda Belli (1980), que aponta que a radionovela foi trazida para o Brasil por meio de Oduvaldo Viana, que era diretor da Rádio São Paulo, e foi nessa época que ele conheceu o gênero em uma viagem à Argentina.

$\mathrm{O}$ autor explica que a radionovela foi vista como uma maneira de expandir o mercado dos produtos de higiene pessoal. O gênero é identificado como uma forma de expandir ao mercado feminino os bens de consumo para casa e de colocar no mercado brasileiro algo que já havia sido testado em outros países. "A radionovela surge portanto como um produto importado, o que significa que no Brasil ela segue um padrão preestabelecido: a) a temática folhetinesca e melodramática; b) o público é composto por donas-de-casa” (ORTIZ, 1989, p. 26).

Ortiz (1989) ressalta que o surgimento da radionovela no Brasil foi tardio. Até o final da década de 1930, o país não contava com um sistema radiofônico em uma estrutura que fosse realmente comercial. $\mathrm{O}$ autor recorre a Geraldo Leite, que aponta que a rádio se tornou um veículo de propaganda a partir dos anos de 1940. Essa passagem é marcada pela substituição de pequenos patrocinadores para grandes multinacionais e, no caso da radionovela, essa mudança de orientação se mostra muito importante, pois as agências publicitárias, que foram criadas pela Gessy-Lever e Colgate-Pamolive, criam seu próprio departamento de rádio e passam a produzir seus próprios conteúdos por meio da contratação de escritores e artistas para adaptação dos textos, como afirma Ortiz (1989). Na década de 1940, os aparelhos radiofônicos ficaram mais acessíveis para o público e isso contribuiu para popularização das radionovelas, como aconteceu em outros países da América Latina.

\subsection{DA RÁDIO PARA A TELEVISÃO: O MELODRAMA NA TV BRASILEIRA}

As radionovelas tiveram muita importância para o surgimento das telenovelas no Brasil. Ortiz (1989) ressalta que se no início as radionovelas eram importadas, com o passar do tempo, os autores começaram a criar textos nacionais devido ao acúmulo de referências sobre o melodrama que, posteriormente, seriam usados para a construção de narrativas televisivas. Para Jesús Martin- 
Barbero e Germán Rey (2001), a radionovela é uma grande mediadora entre a telenovela e a cultura oral. Segundo os autores, a ficção televisiva conserva a predominância do contar e da redundância que se estabelece com a continuidade da narrativa.

A primeira telenovela teve a sua estreia em 1951, na TV TUPI, em São Paulo, e foi exibida até 1963. O autor destaca que a transmissão era feita duas vezes por semana com uma duração de cerca de 20 minutos por capítulo. Como a televisão era um produto recente, havia a preocupação de não transmitir a radionovela na televisão, mas fazer a adaptação das falas da rádio para a TV. No entanto, os atores esbarraram na questão de que eles costumam utilizar a voz e não a expressão corporal, "o resultado é que a locução saía perfeitamente, mas a postura do corpo ficava em total desacordo com as necessidades da cena que estava sendo interpretada" (ORTIZ, 1989, p. 28). Os atores também esbarraram na dificuldade de não conseguir decorar os scripts, pois eles estavam habituados a fazer a leitura diante do microfone.

Ortiz (1989) afirma que, mesmo com as barreiras entre as emissoras de rádios e a televisão, as radionovelas se configuraram em uma fonte de referências para a sua execução. $\mathrm{O}$ autor destaca as dificuldades sofridas na execução dos programas e que os críticos da época apontavam as telenovelas como sendo radionovelas com imagem, que retrata as próprias condições que a televisão se encontrava, como a improvisação e dificuldades econômicas. Ele também comenta que foi com a entrada da TV Excelsior, com bases empresariais mais sólidas, que ocorreu a especialização das funções, como a criação de departamentos para figurino, cenografia e guardaroupas.

O autor ressalta que havia ainda dificuldades técnicas e de caráter operacional nos estúdios. Isso se deve ao fato de as filmagens serem feitas ao vivo e haver pouco tempo para realizar a mudança de cenário e de roupas. Os espaços de gravação eram pequenos e impediam que houvesse muitas movimentações de câmera e a realização de gravações externas aconteciam somente em casos indispensáveis. "Persistia ainda na televisão os velhos hábitos do rádio, os ruídos (tiros, barulho de rua e passos) eram também produzidos na hora pelo contrarregra. Dentro desse contexto, não surpreende que o texto tenha uma primazia sobre a imagem" (ORTIZ, 1989, p. 35). Para solucionar esses problemas de ordem técnica, o narrador surge como uma forma de dar o clima que deveria ser criado pelas imagens.

Ortiz (1989) comenta que, em 1954, acontece uma mudança no eixo dramático e o declínio do "dramalhão". As produções que se seguiram consistiam em uma adaptação de textos 
estrangeiros de novelas infantis, “[...] autores consagrados pela literatura popular internacional, passam agora a ter suas obras apresentadas no vídeo" (ORTIZ, 1989, p. 36). Além da inspiração nas obras literárias, o cinema se torna uma referência para a produção e execução das telenovelas.

Os filmes se apresentavam como um produto muito importante para quem fazia televisão na década de 1950 no Brasil. As películas eram utilizadas como forma de legitimar algumas obras que eram exibidas nas telas e a sua adaptação era vista como importante para garantir o sucesso da sua exibição. Além disso, os seus scripts facilitavam o trabalho da redação das adaptações; os enquadramentos, angulações e efeitos eram referências para as produções de telenovela, “[...] na medida em que o rádio fornecia aos iniciantes um passado exclusivamente sonoro, restava ao cinema cumprir o papel de modelo imagético" (ORTIZ, 1989, p. 40).

Os grandes anunciantes tinham certo receio de investir na televisão brasileiro. Ortiz (1989) comenta que eles entendiam o mercado nacional como incipiente, então demandava coragem e ainda havia a margem de risco. Havia a necessidade de dirigir a publicidade ao público e, ao mesmo tempo, criar um mercado na televisão que existia de forma parcial. Além disso, apenas alguns locais, como “[...] São Paulo (1950), Rio de Janeiro (1951), Belo Horizonte (1955), Porto Alegre (1959) - eram cobertos pela TV, o que restringia o mercado consumidor" (ORTIZ, 1989, p. 42). Outro ponto que explicava o maior investimento nas radionovelas do que nas telenovelas era o fato de que as empresas de produtos de higiene, como Colgate-Palmolive e Gessy-Lever, promoviam uma vinculação orgânica entre o melodrama e as questões comerciais, e isso não ocorria com as telenovelas. Essa relação acontecia porque as empresas de produtos de limpeza já possuíam seus próprios departamentos de rádio e não de telenovelas.

Ortiz (1989, p. 42) destaca que "[...] a escolha do texto, assim como a sua adaptação, era assunto que dizia respeito à emissora o que significa uma certa independência em relação às pressões comerciais". Nessa situação, a televisão possuía os programas que foram herdados do rádio, como novelas, shows de calouros e programas humorísticos e também abriu um espaço para um lado mais cultural, como o teatro e o teletrato, que se consagrou enquanto programa de maior prestígio da televisão brasileira nos primeiros anos da década de 1950.

O início da televisão brasileira contou com a participação de profissionais do rádio e não do cinema ou do teatro e, para Ortiz (1989), isso resultou na criação de uma TV medíocre, devido à falta de formação voltada para a área visual. Em meio a esse contexto, a telenovela surge da radionovela e se afasta do teatro e do cinema, e é classificada como desqualificada. Ortiz (1989) 
afirma que, para afastar a telenovela da sua herança melodramática das radionovelas, a estratégia adotada foi a adaptação de filmes estrangeiros como forma de colocar o gênero em uma posição intelectual mais elevada.

É na década de 1960 que percebemos que as obras de autores nacionais foram utilizadas como referência para a construção dos programas no Brasil. O autor destaca que esse quadro com a criação da TV Excelsior, que pertencia ao grupo Simonse, era fortemente nacionalista. Nesse sentido, as produções de telenovela também são voltadas para essa adoção de textos nacionais com o objetivo de se voltar para o ritmo cultural e político.

Na década de 1960, as telenovelas chegam com desprestígio, mas, ao mesmo tempo, o autor evidencia que elas passaram por uma década e que é possível perceber algumas mudanças no comportamento do público. As telenovelas começaram a ter mais expressão no cenário nacional do que os teleteatros. Segundo Ortiz (1989), a telenovela supera os programas culturais em conjunto com a popularização da televisão.

\subsection{A TELENOVELA NA CASA DOS BRASILEIROS: A TELENOVELA DIÁRIA}

Renato Ortiz, Silvia H. Simões Borelli e José Mário Ortiz Ramos (1989) destacam que o surgimento da telenovela aconteceu em meio à improvisação técnica, empresarial e organizacional da TV brasileira. Essa percepção se altera na década de 1960, contudo Ortiz, Ramos e Borelli (1989) ressaltam que essas mudanças não se configuram na parte técnica, como a integração nacional por meio dos satélites, edição eletrônica e cor, mas elas são o suficiente para que a telenovela se consolide como uma indústria cultural. Tal mudança também é resultado da expansão da quantidade de aparelhos de televisão no país, como Ortiz, Ramos e Borelli (1989) e Ortiz (1989) apontam. E Martín-Barbero e Rey (2001) completam essa discussão ao apresentar que, na América Latina, o melodrama resultou em uma matriz cultural que promove o reconhecimento popular na cultura de massas e um território para estudarmos a não-simultaneidade do contemporâneo como uma chave para a mestiçagem que somos feitos.

Ortiz, Ramos e Borelli (1989) recorrem aos dados de Menezes (1975) e apresentam que a rede televisiva chegou ao Rio de Janeiro e a São Paulo em 1950; a Belo Horizonte em 1955; a Porto Alegre, Ribeirão Preto e Bauru em 1959; a Recife, Salvador, Curitiba, Fortaleza, Brasília e Guaratinguetá em 1960; a Belém em 1961; a Uberlândia em 1962; a Londrina e São Luiz em 1963; 
e a Juiz de Fora em 1964. Mesmo que não houvesse a cobertura de todo o país, percebemos que houve a ampliação da área de abrangência do sinal de televisão.

Rede importante, na medida em que a introdução de novas tecnologias, o videoteipe, permitem que determinados programas tenham agora uma circulação mais ampla. A televisão começa realmente a se implantar como um veículo de massa, transformação que implica numa reorientação do seu financiamento (ORTIZ; RAMOS; BORELLI, 1989, p. 79).

Com a expansão da rede televisiva e o aumento do investimento, houve uma mudança na forma de gestão do patrimônio das emissoras de televisão. Os autores evidenciam que esse período foi marcado pela racionalização dos processos que envolvem a expansão da televisão e implantação de uma visão empresarial. Nessa nova perspectiva, Ortiz, Ramos e Borelli (1989) apontam para a racionalização do tempo que permitiu que a programação passasse a ser organizada de forma horizontal, em horários determinados - assim, os programas param de se atrasar e são transmitidos diariamente - e de forma vertical, na qual a programação é exibida em sequência para fixar o telespectador no mesmo canal.

A outra forma de racionalização vem relacionada à ordem mercadológica. As empresas começam a criar logotipo, slogan e passam a se apresentar como uma marca para o público e para o mercado publicitário. Assim, os autores apontam que eles passam a se autopromover, como a TV Excelsior, que foi a primeira a fazer propaganda de si mesma. Outra questão que influenciou na organização das emissoras de televisão foi a mudança na relação com os integrantes do corpo artístico; também nesse aspecto a Excelsior foi pioneira e formou um corpo técnico e artístico oferecendo um salário mais elevado para os profissionais da área.

Os administradores da TV Excelsior perceberam que era preciso investir na contratação de um corpo técnico especializado para implantar uma empresa moderna e que esse processo de contratação também estava ligado ao de racionalização pelo qual a emissora passava. Com essas transformações, a telenovela diária segue a mesma lógica das soap-operas, nos Estados Unidos, e das radionovelas, que vêm como uma narrativa utilizada para ampliar o público da emissora.

Ortiz, Ramos e Borelli (1989) mostram o caso da primeira telenovela diária, a 2-599 ocupado, que foi interpretada pelo Tarcísio Meira e Glória Menezes e era de autoria do argentino Alberto Migré. O programa foi ao ar em 1963, na TV Excelsior, mas foi exibido três vezes na semana como uma experimentação, e, após esse período, ela passou a ser transmitida todos os dias, 
de segunda a sexta-feira. Além disso, eles apontam que a exibição é utilizada como uma forma de conquistar o mercado. Seguindo a mesma lógica das soap-operas e das radionovelas, as telenovelas se tornaram meios de divulgar produtos na televisão e apresentar o ressurgimento dos vínculos das fábricas de sabão, como era feito nos anos anteriores.

Arthur da Távola (1996) ressalta que a transmissão diária da telenovela surgiu em 1963, mas o gênero só ficou popular em 1965, com a telenovela O Direito de Nascer. Essa ficção seriada foi o marco da evolução do gênero, em especial devido ao fato de um mercado de telespectador ter sido criado primeiramente no Rio de Janeiro e em São Paulo e, 10 anos depois, em outros lugares no Brasil.

Ortiz, Ramos e Borelli (1989) ressaltam que, durante a década de 1960, a presença das empresas de produtos de higiene pessoal era marcante no patrocínio dos programas brasileiros. Essas organizações tiveram um papel importante na consolidação da indústria da televisão no país, pois as emissoras tinham força para se tornar veículos de massa, no entanto o que lhes faltavam eram os recursos para se autonomizar e se tornar fonte produtora. As empresas que patrocinaram os programas criaram uma rede na América Latina e os escritores iniciaram as suas carreiras fazendo adaptações de obras estrangeiras ou nacionais até adquirirem experiência para iniciar a sua própria escrita. Os autores afirmam que essa circulação de textos era facilitada pela posição privilegiada das agências de propaganda nos países. Távola (1996) aponta como exemplo, a telenovela $O$ Direito de Nascer, que é uma obra mexicana e que foi trazida para o Brasil por José Bonifácio de Oliveira Sobrinho, o Boni, que conseguiu o patrocínio da Lever para pagar os custos da produção em troca da exclusividade.

Os pesquisadores mostraram que o sucesso das telenovelas diárias foi rápido, mesmo que ainda houvesse alguma dificuldade para que os telespectadores se acostumassem com as transmissões diárias.

\footnotetext{
Aos poucos o público se habituava a fixar os horários, organizados e administrados pelas grandes redes. Com o surgimento do videoteipe, permitiu-se não somente a produção da telenovela diária, como também sua veiculação dentro de um esquema de "horizontalidade" dos programas (ORTIZ; RAMOS; BORELLI, 1989, p. 61).
}

Com essa organização dos horários no quadro da programação das televisões, o telespectador começou a se habituar aos momentos que as telenovelas seriam exibidas e isso acabou 
entrando no cotidiano das famílias. Os autores explicam que, entre 1963 e 1969, os números de telenovelas exibidas eram maiores do que entre 1951 e 1963, e, além disso, elas passaram a ser exibidas diariamente e se tornaram o produto que fez com que as emissoras começassem a concorrer entre si - a "programação obrigatória das emissoras, elemento fundamental na distribuição dos horários e dos custos, a novela é também responsável pela elevação dos índices de audiência" (ORTIZ; RAMOS; BORELLI, 1989, p. 63).

No ano 1965, a telenovela se torna um objeto de valor na programação da TV Excelsior, assim, o horário de 19 horas e 20 horas e 30 minutos, que antes eram preenchidos com filmes ou telejornalismo, passam a exibir as telenovelas, que foram valorizadas para serem transmitidas na prime-time. Esse período entre 1963 e 1969 foi marcado pelo aumento na produção de telenovelas, e Ortiz, Ramos e Borelli (1989) afirmam que isso mostra o crescimento do consumo das teleficções, que são utilizadas por emissoras pequenas para atrair o público e, também, como sendo um momento de experimentação das produções. Para os autores, esse cenário representa uma falta de organização e modelo de produção que fizesse uma racionalização entre duração e custo operacional, e essas questões são melhores equacionadas com a consolidação de uma indústria televisiva, que é inspirada no Sistema Globo de Televisão.

Para Távola (1996), a década de 1960 também foi marcada por mudanças na lógica de produção televisiva, como a implantação de uma consciência profissionalizante; entrosamento dos setores dentro da emissora; desenvolvimento técnico - utilização do videoteipe -; implantação de técnicas publicitárias; e o encontro de uma linguagem específica para a televisão. Além dos desenvolvimentos internos das emissoras televisivas, Ortiz, Ramos e Borelli (1989) e Távola (1996) apresentam o crescimento do número de aparelhos televisivos no Brasil, que contribuiu para a criação de um mercado para a consolidação dessa indústria cultural; assim, "o telespectador começava a ganhar produtos profissionalizados, e a tevê a incorporar emoções antes pertencentes exclusivamente ao cinema" (TÁVOLA, 1996, p. 82).

Ortiz, Ramos e Borelli (1989) trazem uma fala da autora Ivani Ribeira (1979) que destaca que o telespectador gosta de se identificar com as histórias e os locais nos quais as suas histórias se passam e que o importante é que a trama se relacione com o que acontece na vida real. Os autores ressaltam que os textos e roteiros eram adaptados de acordo com o público brasileiro e que elas passavam por modificações que garantiam que essa adaptação ocorresse. Assim, eles também ressaltam que é importante utilizar a forma narrativa herdada do folhetim melodramático na 
introdução das telenovelas diárias devido aos efeitos que ela causa no público, como a criação do hábito de acompanhar a trama diariamente e a facilidade da implantação da horizontalidade na grade de programação. Ao final da década de 1960, a telenovela começa a se aproximar da atmosfera cultural brasileira, o que era pouco percebido no início desse período. Para os autores, essa mudança se dá a partir da crise que se instaura nas propostas anteriores após o golpe de 1964 e com a implantação do processo de modernização da sociedade que é intensificado e promove a reorientação de vários campos. A "complexificação da sociedade e produção de cultura voltada para um amplo mercado de bens simbólicos são marcas deste novo período" (ORTIZ; RAMOS; BORELLI, 1989, p. 80). Esse é o cenário que corresponde para os autores como o momento em que a televisão se consolida enquanto indústria cultural.

O período de 1970 e 1980 também ficou marcado pelo aumento do número de aparelhos de televisão no território nacional, além da mudança na estrutura organizacional, adoção de inovações tecnológicas e racionalização da produção. A busca por padrões de superioridade no campo empresarial, estabilização da programação, ampliação do campo de atuação e aumento da qualidade dos programas de ficção televisiva, como as telenovelas, fizeram com que a TV Globo se tornasse um exemplo de emissora, como comentam os autores:

\footnotetext{
Desde o governo Castelo Branco, o Estado autoritário passa a se preocupar com os assuntos de cultura, procurando realizar diretrizes que favoreçam o desenvolvimento de uma "cultura brasileira", de uma "identidade nacional" compatível com suas premissas coercitivas. Esta movimentação estatal, combinada com censura e incentivo no plano econômico, já foi devidamente analisada, nos interessa aqui vincular esta atmosfera político-cultural com a televisão e particularmente com a telenovela (ORTIZ; RAMOS; BORELLI, 1989, p. 84).
}

Percebemos que o sucesso da TV Globo também está ligado ao diálogo que a emissora teve com o governo autoritário daquela época. Como foi apontado pelos autores, o interesse dos governantes era criar uma identidade nacional e uma cultura brasileira por meio dos programas televisivos. Nessa perspectiva, Ortiz, Ramos e Borelli (1989) apresentam que havia uma preocupação com o que deveria ou não ser mostrado nas telas, de forma que somente o talento e a criatividade chamassem a atenção para os programas de televisão nacional. Para Maria Immacolata Vassallo de Lopes (2008), a telenovela consegue criar o sentimento de pertencimento porque ela conecta as dimensões temporais de passado, presente e futuro por meio da construção e antecipação 
de expectativas de eventos ou âmbitos específicos. Segundo ela, a televisão pode contribuir para a identidade nacional porque ela dá espaço para as representações e diferentes partes sociais conseguem ter acesso ou ser representadas.

Ortiz, Ramos e Borelli (1989) explicam que as interferências políticas na comunicação nacional resultaram na introdução de telenovelas que foram solicitadas pela esfera estatal em horários menos importantes para a TV Globo, como às 18 horas e às 22 horas. Essas produções tinham o enfoque nacionalista em níveis que são de temas mais educativos. Desta forma, a telenovela é vista como uma proposta simplista e como um serviço de utilidade pública. Os autores ressaltam que, com a publicação da Política Nacional de Cultura ${ }^{9}$, o horário das 18 horas foi direcionado para a adaptação de obras literárias nacionais, como Helena, de Machado de Assis, e Senhora, de José de Alencar, que combinam com o regaste da nacionalidade por meio dessa política cultural. E as telenovelas eram vistas pelo Ministério da Justiça da década de 1970 como um instrumento valioso para a educação e para a deturpação dos valores que interessavam ao governo, que foi uma pauta levantada em debates trazidos pela telenovela Roque Santeiro, de 1975.

Outras alterações que puderam ser percebidas no final da década de 1970 nos programas de ficção foram o afastamento das temáticas destinadas às mulheres, que é uma herança das radionovelas para a aproximação do público masculino, como o programa Irmãos Coragem (1970/71), que aborda assuntos como futebol e garimpo (ORTIZ; RAMOS; BORELLI, 1989). Com relação à narrativa das telenovelas, Távola (1996) comenta que o período do final de 1980 e início de 1990 foi marcado pela abordagem de temáticas mais ousadas e que estavam ligadas à sensualidade, sexo fora do casamento, emprego de gírias e linguajar menos formal e uso de roupas mais sumárias. Essas mudanças causaram um efeito nos conservadores brasileiros, pois, conforme aponta o autor, rompem com a lógica que estava orientando os programas e isso acaba fazendo com que o gênero fique mais polêmico.

\footnotetext{
${ }^{9}$ Ana Luíza Rezende Garcia (2013) destaca que essa Política Nacional de Cultura foi elaborada no final de 1975 e apresentou fundamentos legais da ação do governo na área da cultura. Essas diretrizes nortearam o trabalho do MEC; apresentou ideais e programas; exibiu as ações do Estado; e revelou os itens que concentram o que é a cultura brasileira e de política cultural.
} 


\subsection{AS TELENOVELAS COMO PRODUÇÃO DA CULTURA MIDIÁTICA}

Jesús Martín-Barbero (1997) apresenta que, nos anos de 1940 e 1950, para os pensadores europeus, a sociedade de massa representa a degradação, morte lenta e negação. E para os teóricos da América do Norte, a cultura de "massas representa a afirmação e a aposta na sociedade da democracia completa" (MARTÍN-BARBERO, 1997, p. 57). Assim, a cultura produzida pelos meios massivos se torna a cultura de massa, como a cultura do povo.

$\mathrm{O}$ autor ainda afirma que os meios de comunicação de massa carregam a função de mudança na cultura de uma sociedade como mentores da nova conduta e transformam as formas de vestir até os aspectos morais. Com o deslocamento da política para a cultura, Martín-Barbero (1997) destaca que a análise vai além das classes sociais e se torna uma questão de desnível cultural, que vira uma outra forma de organização e circulação do que o autor chama de nova riqueza, que é a variedade de experiências culturais.

Martín-Barbero (1997) afirma que é a partir da Escola de Frankfurt que os procedimentos de massificação não são pensados apenas como substitutivos, mas também como constitutivos da conflitividade da estrutura social. A unidade da indústria cultural pode se tornar mais clara na dimensão que o autor chama de "a degradação da cultura em indústria de diversão" (MARTÍNBARBERO, 1997, p. 66). Ele destaca que, quando Adorno e Horkheimer fazem essa relação, eles aproximam a análise da experiência cotidiana e de como o capitalismo articula os dispositivos que são do ócio e do trabalho. Segundo o autor, a diversão torna a vida inumana algo suportável, que inocula a capacidade dos sujeitos de se encaixarem e se conformarem com seus contextos e gera a morte e a capacidade de estremecimento da rebelião.

A arte é incorporada ao mercado como um bem cultural e se adequa às necessidades que o próprio mercado propõe. O autor afirma que, ao ser reduzida a cultural, a arte se torna acessível ao povo. A indústria cultural aproveita esse contexto e oferece o que Martín-Barbero (1997, p. 69) chama de "arte inferior", que não obedece ao conceito de arte. Esse estilo de arte sempre foi desobediente e criou um estilo próprio, da mesma forma que o humor faz.

Na América Latina, Martín-Barbero (1997) destaca que é a mestiçagem que constitui a população não só como um fato social, mas como uma razão de ser que é composta de temporalidades, espaços, memórias e imaginários. Para ele, esse entendimento se configura em uma nova sensibilidade política que é mais aberta à institucionalidade, à cotidianidade, à 
subjetividade dos atores e à multiplicidade de solidariedade. A mestiçagem permite pensar na vigência cultural das diferentes identidades que se vem adquirindo, como o indígena no rural, o rural no urbano, o folclore no popular e o popular no massivo.

Nos anos de 1930, a América Latina experimenta a entrada da industrialização independente, do rádio e do cinema. $\mathrm{O}$ autor explica que o populismo se torna um nacionalismo na cultura e encontra nos cinemas mexicano e argentino a melhor forma de expressão. Ele afirma que, para criar um país, é preciso teatralizá-lo, e o cinema fica responsável por fazer essas representações e dar imagem e voz ao que faz parte das identidades nacionais. As massas populares vão ao cinema principalmente para se divertir, mas também para fazer experimentos da vida cotidiana e renovar os códigos e costumes - "é um cinema que, como assinalamos acima, faz nacionalismo a partir do melodrama: gênero capaz de estruturar qualquer tema ou situação ao mesmo tempo evocando mitos e massificando modos de comportamento" (MARTÍN-BARBERO, 1997, p. 267).

Martín-Barbero (1997) destaca que, a partir dos anos de 1960, a cultura urbana passa a ser ocupada pela indústria cultural, que tem uma influência cada vez mais abrangente e busca modelos no mercado transnacional. Para ele, a proposta cultural que se segue é a sedução tecnológica e incitação do consumo, a homogeneização do consumo, estilos de vida e banimento do nacionalismo e incorporação dos conteúdos sociais, culturais e religiosos à cultura do espetáculo. A televisão apresenta uma fala unificada para todo o país, que escapa apenas quando se fala de folclore e entonações regionais.

Muniz Sodré (1984, p. 09 - grifo do autor) apresenta que a televisão é o meio de comunicação que se tornou a "síntese hegemônica dos discursos, das práticas $<<$ artísticas $>>$, das diferentes possibilidades de linguagens". Ele ressalta que qualquer tentativa de entender a televisão como um meio isolado do seu modo de produção e das relações com os outros meios será insuficiente. Para o autor, a imprensa é uma forma de transmitir informações sobre a vida cotidiana, mas também é um meio de centralizar o poder e disciplinar o cidadão.

O leitor de jornal, o público de massa, são categorias (abstrações) produzidas a partir desse poder organizador de linguagem constituído pelo medium, isto é, pela mediação técnica entre o falante e o ouvinte, informante e informado. É dessa maneira que a imprensa marca o início da moderna disciplina do diálogo pelo Poder (SODRÉ, 1984, p. 16). 
O autor afirma que esse poder promovido pela mídia faz uso dos mecanismos de disciplinamento, que foi analisado pelo Michel Foucault e recebe o nome de panóptico ${ }^{10}$. No que tange a área da comunicação, Sodré (1984) comenta que a periodicidade com que os jornais são publicados contribui para que exista a regulação e manutenção do panóptico do espaço social. Nesse sentido, “a televisão, imbricada com as instituições fundamentais da civilização ocidental (capital, família, democracia, escrita, é o mais recente e mais acabado momento técnico do panoptismo social" (SODRÉ, 1984, p. 17).

Sodré (1984) busca traçar as funções da linguagem e conceitos da televisão e ele afirma que o que podemos encontrar como sendo um conceito de televisão "é a forma de relações sociais a que ela induz a partir de sua sistematicidade operacional" (SODRÉ, 1984, p. 21). Dessa forma, o autor considera que os meios de informação podem ser usados pelo Estado como um instrumento ideológico que tem uma relação contraditória, pois podem apresentar conteúdos que choquem com os interesses dominantes e as políticas conservadoras.

Para ele, a televisão é diferente dos outros meios de comunicação, pois ela contém as funções que os meios de comunicação precedentes preenchiam e ainda utiliza da função audiovisual. Sodré (1984, p. 28) afirma que “o medium não é aí um simples mediador entre informante e público, mas um espaço autônomo capaz de criar modelos próprios, que neutralizam o sentido político das ações e dos discursos". Nessa perspectiva, o autor destaca que a televisão não é só um dispositivo tecnológico, ela cria uma realidade particular que recobre o espaço social que tem uma relação semelhante ao espaço físico-geográfico local. A linguagem da televisão, para o autor, se assemelha à do jornalismo, pois o seu objetivo é mostrar o que está acontecendo fora do vídeo, mas que esteja supostamente no tempo histórico do espectador.

No que tange à representação da realidade nas telas da televisão, Sodré (1984) apresenta que a telenovela brasileira é um exemplo do drama televisivo. Para ele, esse imaginário proposto por essa ficção televisiva é comandado pelo princípio da realidade ou pelo real histórico que vem sendo influenciado pela produção da televisão, censura e a incorporação de acontecimentos no noticiário jornalístico. Dessa forma, "essa vinculação da linguagem do vídeo ao real histórico indica que a simulação televisiva só é efetiva se o medium sabe captar traços característicos de seu

\footnotetext{
${ }^{10}$ Sodré (1984) comenta que esse conceito foi criado por Jeremy Bentham em 1972 e se remete a uma penitenciária na qual os presos são vigiados por um inspetor que observa, mas não pode ser visto. E ele mostra que, para Bentham, esse poder anônimo é a democracia, que é um sistema no qual qualquer sujeito pode chegar ao poder ou até mesmo fazer o exercício de vigilância.
} 
público, para bem realizar o <<contato $>>$ "(SODRÉ, 1984, p. 80 - grifo do autor). O autor afirma que todo folhetim é vinculado a alguma moral, que pode ser a do processo civilizatório e a doméstica. Ele afirma que as telenovelas se vinculam ao quesito doméstico, pois elas restituem ao público a realidade da moral caseira no campo semântico da família e transmitem a filosofia do senso comum, sendo que ele é oriundo das formas de poder daquela sociedade.

Para Martín-Barbero (1997, p. 304), o gênero mais expressivo na América Latina é o melodrama, "é como se estivesse nele o modo de expressão mais aberto ao modo de viver e sentir da nossa gente". Ele destaca que o melodrama é como as praças de mercado em que acontecem as misturas de estruturas sociais, sentimentos, sonhos e o que as pessoas desejam ser. E, nesse gênero televisivo, o que está em jogo, segundo o autor, é o drama do reconhecimento que move o enredo.

Arthur da Távola (1996) afirma que, para analisar as telenovelas, é preciso considerar os padrões mercadológicos, produtivo-tecnológicos e artísticos. Para o autor, esses programas ligam diferentes formas de leituras que podem ser concomitantes ou antagônicas e, além disso, "o produto-programa possui ainda como outro aspecto a sua relação, via propaganda, com o público e com o processo econômico do país" (TÁVOLA, 1996, p. 07).

Quando se fala do padrão mercadológico, o autor ressalta que as emissoras de televisão buscam adequar o seu produto às vontades, necessidades e ao universo conceitual do público. A intenção, segundo Távola (1996), é dominar as técnicas que incentivem a vontade de compra do público e que os canais aperfeiçoem a sua relação com o mercado, e "se por um lado limita o produto artístico a sua eficácia mercadológica, por outro democratiza a possibilidade da comunicação, porque sai do amanho exclusivo do artista, ausculta o universo conceitual do público que lhe obedece" (TÁVOLA. 1996, p. 08). Nesse sentido, é preciso que os produtos-programas abordem elementos que se relacionem com o repertório de estética, ideologia e semântica das pessoas.

O padrão artístico se refere à obtenção de um padrão de qualidade que atinja um determinado segmento da sociedade. Távola (1996) ressalta que não se trata de um conteúdo de valor, mas sim da conquista de um padrão de produção, que ficou conhecido como o "padrão de qualidade" denominado pela Globo. "Pode não ter o padrão exigido pelas elites intelectuais nem alcançar valor artístico, mas possui a capacidade de operar sobre a sensibilidade dos segmentos mercadológicos que quer conquistar" (TÁVOLA, 1996, p. 10). 
O autor ressalta que existia uma televisão antes do videoteipe e das cores e outra depois que essa tecnologia foi implantada. Além disso, para ele, a influência da tecnologia se dá na racionalização das técnicas de produção e também no resultado dos programas. O padrão éticocultural diz respeito ao valor do conteúdo e a sua finalidade. Távola (1996) declara que toda sociedade vive em meio a seus valores estéticos e éticos sociais e que o conjunto de valores, ideias e ideologia influenciam no produto-programa. No entanto, essa orientação é feita com base nos padrões éticos-culturais que dominam a sociedade.

\begin{abstract}
A tevê incorpora tendências emergentes em estado de aceitação ou já aceitas, operando com o código conservador. Mas como precisa avançar na relação com o mercado, conduz o código conservador ao seu limite do permitido. E o máximo que se concede é a transgressão, imediatamente calada para que o código volte a imperar. Os sistemas permitem a infração, jamais a revogação ou substituição do código pelo qual asseguram os conteúdos da ideologia dominante (TÁVOLA, 1996, p. 13).
\end{abstract}

Para Douglas Kellner (2001), o rádio, televisão, cinema e outros produtos da indústria cultural fornecem modelos do que é ser homem ou mulher, ser bem sucedido ou não, poderoso ou impotente. E, segundo o autor, a cultura midiática fornece o material necessário para que as pessoas construam o seu entendimento do que é classe, raça, nacionalidade, sexualidade, "nós" e "eles". Para Távola (1996), a televisão brasileira é branca, urbana e adulta, sendo que ela é feita em um país mestiço; assim, a ideologia dominante é oriunda de uma minoria dominante: "a televisão é um 'aparelho ideológico' como os outros meios de comunicação - destinado a manter as condições de produção dominante. Tudo ocorre dentro dessa condição fundamental” (TÁVOLA, 1996, p. 14).

A partir dessa perspectiva e desses padrões apresentados por Távola, o autor destaca que o produto-programa vai pender para cada um dos lados de acordo com os interesses da emissora. Neste caso, aquelas voltadas para o mercado dão ênfase ao padrão mercadológico e produtivotécnico e subordinam os demais. Kellner (2001) destaca que a cultura é uma forma de atividade de alto grau de participação em que as pessoas criam o seu entendimento do que é sociedades e identidades. Essa cultura molda os indivíduos por meio da evidenciação, do cultivo das potencialidades e capacidades de fala, ação e criatividade. E a cultura da mídia também participa desse processo em conjunto com a cultura de consumo, atuando para criar pensamentos e comportamentos que são ajustados a valores, instituições, crenças e práticas vigentes. 
Segundo Peter Berger e Thomas Luckmann (2004), a vida cotidiana é uma realidade interpretada pelos homens e é subjetivamente dotada de sentido para as pessoas, na forma em que eles formam um mundo coerente. Os autores destacam que a vida cotidiana está organizada com foco no aqui e no agora dos sujeitos e a realidade da vida diária não foca apenas o momentâneo, mas une outros fenômenos que não estão presentes no exato momento.

Os autores afirmam que a realidade na vida cotidiana é partilhada com outros indivíduos que estão na situação de face a face e o que esse sujeito se torna acessível por meio desse contato. Segundo Berger e Luckmann (2004), a realidade social da vida cotidiana possui esquemas de tipificação que são aprendidos pelas outras pessoas e que orientam a forma como os sujeitos vão lidar com os outros no encontro face a face. E essas tipificações interferem e modelam a forma com que os sujeitos se relacionam.

Em relação ao discurso das telenovelas, Távola (1996) comenta que o discurso é conservador, pois é feito em um veículo que já possui um discurso dominante, apesar dos programas de ficção televisivas serem feitos por intelectuais e críticos do sistema. Em 1996, o autor avaliou que o público ainda preferia que as tramas fossem feitas conforme o drama românticorealista e conservador e destacou que desse romantismo individualiza a forte dose de sentimento e a falta de lógica que existe nas atitudes românticas. Ele ainda ressaltou que a telenovela pegou a verossimilhança emprestada do realismo, a busca por meio dos personagens, o retrato da verdade e a representação da realidade da sociedade brasileira, mas sempre dentro do discurso conservador da mídia, assim, "a telenovela é narrativa realista repleta de romantismo, e narrativa romântica carregada de realismo" (TÁVOLA, 1996, p. 20).

Távola (1996) afirma que a telenovela possui aspectos inusitados na história da indústria da comunicação e que é possível eliminar a possibilidade de paralelismo com outras obras que também fazem parte na obra televisiva. A telenovela é construída a partir da resposta dos telespectadores: "é dos raros campos da criação dramática em que o feedback opera e influi concomitantemente à criação" (TÁVOLA, 1996, p. 33).

O autor ressalta que essas ficções seriadas têm contato com o público ao longo de quase um ano e os personagens são alterados, e os telespectadores também podem ser influenciados por meio desse contato. Isso acontece porque as telenovelas são programas construídos ao mesmo tempo em que estão sendo exibidas, no que Távola (1996) chama de coautoria. "Enquanto pesquisas determinam a 'subida' de um personagem, 'descida' de outro, glorificação ou rechaço, feedback 
quase imediato propicia novas informações ao autor que ajusta a obra pai passu às reações do público" (TÁVOLA, 1996, p. 49).

Para Esther Hamburger (2011), a televisão se estabelece como o meio que fala para diferentes segmentos da sociedade, faixas etárias e regiões. Jésus Martín-Barbero e Gérman Rey (2001, p. 118) completam que "a produção da telenovela representou, por sua vez, uma certa apropriação do gênero em cada país: sua nacionalização”. Dessa forma, Mauro Alencar (2002) reitera que a telenovela é o gênero em que os códigos de ética são transmitidos aos telespectadores. $\mathrm{O}$ autor ressalta que é nesse processo que as pessoas de áreas rurais podem começar a agir como as das cidades grandes, como o Rio de Janeiro e São Paulo. A partir do momento que esses padrões sociais são recriados nas telas, eles passam a ser imitados, da mesma forma que acontece na sociedade de consumo.

\subsection{CRIADA PARA ATINGIR O PÚBLICO FEMININO}

As produções melodramáticas foram destinadas ao público majoritariamente feminino, como podemos perceber com o uso das soap operas para fazer a divulgação de produtos de limpeza, conforme apresentado por Ortiz (1989). As principais patrocinadoras dos programas eram empresas que produziam produtos de limpeza, que faziam parte do dia a dia das donas de casa. Segundo Ortiz (1989), as soap operas eram o meio utilizado para chegar até as mulheres com a intenção de fazer com que elas tivessem conhecimentos do que era oferecido por essas indústrias, já que esse público foi identificado como principal responsável pela compra desses insumos para o lar. Com a chegada da televisão e o desenvolvimento das telenovelas, Ortiz, Ramos e Borelli (1989) comentam que foi durante a década de 1960 que as empresas de higiene pessoal marcaram presença como patrocinadoras dos programas televisivos e tiveram a influência no estabelecimento da indústria televisiva no Brasil.

Segundo Heloisa Buarque de Almeida (2002), os meios de comunicação como o rádio e a televisão são intermediários muito relevantes nas mudanças de padrão de consumo e no universo que abrange as representações sociais para os indivíduos no que se refere ao amor, ao casamento e às relações familiares. Para a autora, a televisão foi o meio de promover a formação de um mercado consumidor no Brasil a partir da década de 1960. Assim, esse meio ampliou o mercado publicitário 
devido ao seu modelo comercial e contribuiu para a formação de um padrão profissional no mercado publicitário.

Almeida (2002) comenta que a intenção era fazer com que os espectadores fossem também consumidores e a telenovela adquire esse papel ativo dentro dessa lógica. A autora aponta que a publicidade vende diversos produtos, mas, como um fenômeno social, ela promove os produtos, os hábitos de compra e o consumo. Nesse sentido, Almeida (2002, p. 30) comenta que a publicidade funciona como um "processo civilizador" que apresenta aos consumidores o desejo e a necessidade de ter bens para se modernizar e "[...] a mulher é vista como consumidora por excelência, pois é ela que compra a maior parte dos produtos".

Para a autora, esse gênero televisivo também já era visto como um programa feminino, assim, "supõe-se que as imagens construídas pela mídia têm um sentido evidente e direto de reforço de noções e construções de gênero, ou papéis femininos e masculinos, que reproduzem as desigualdades geradas pelo patriarcalismo" (ALMEIDA, 2002, p. 35).

Quando as telenovelas exibem padrões de consumo a diferentes classes sociais e regiões do país, elas acabam criando alguns padrões de sentido simbólico. Almeida (2002) apresenta que o que está na "última moda" pode tornar os consumidores semelhantes e carrega os sentidos simbólicos de ser moderno, estar atualizado, cuidar-se e manter-se bonita, por exemplo. Ela ainda completa que a telenovela se torna a vitrine que acostuma o telespectador aos diferentes estilos de moda e de vida. Dessa forma, é pela possibilidade de acessar ou não bens de consumo e pela escolha de cada bens que a autora destaca ser uma das marcas das diversas classificações sociais em uma sociedade de consumo que são os recursos utilizados para realizar a leitura das divisões sociais. Esther Hamburguer (1998) diz que os modelos de homem e mulher, de relacionamento e de organização familiar são divulgados pelas telenovelas e são constantemente atualizados. Ela destaca que as angústias privadas das famílias de classe média das cidades do Rio de Janeiro e São Paulo são transmitidas para todo o território nacional e que as novelas estabelecem padrões com os quais a população não necessariamente concorda, mas que servem de referências legítimas para que eles tenham algum posicionamento.

Segundo Almeida (2002), a telenovela participa da construção da representação de gênero e contribui para a formação da figura da mulher "batalhadora", da identificação do que é o corpo, a partir dos modelos de moda beleza. 
Os padrões de comportamento, ou as atitudes consideradas legítimas para homens e mulheres, constituem-se nestas construções de gênero da mídia. As novelas, especialmente em seus aspectos mais repetitivos, por características e elementos presentes em muitas histórias, legitimam algumas construções de feminino e masculino - como a figura da mulher batalhadora (ALMEIDA, 2002, p. 191).

As telenovelas têm como uma de suas características a repetição de temas e isso promove o interesse do público e permite a facilidade da compreensão, como comenta Almeida (2002). Ela reitera que a utilização dessa redundância e as repetições permitem que a história seja compreendida pela parcela da população que possui um capital cultural menor ou menos envolvimento com a linguagem televisiva. O seu entendimento só acontece depois que as narrativas televisivas utilizam do recurso da repetição algumas vezes, e esse recurso, segundo Almeida (2002), é o que fixa na memória dos telespectadores.

A partir desse contato e da fixação das narrativas televisivas na memória dos telespectadores, a autora evidencia que é esse entendimento extraído da repetição que fornece capital para que o público faça comparações entre as histórias que eles acompanham. É por meio das repetições que os espectadores também criam a noção de um indivíduo autônomo e que luta contra os obstáculos para conquistar o amor, ascensão social e a realização profissional - esses se tornam os valores difundidos nas telenovelas, principalmente pelas personagens femininas.

A autora também ressalta que as narrativas desses programas realizam um comentário cultural sobre a sociedade que está em processo de transformação, mas que nem sempre são de concepções coerentes ou complementares. As telenovelas, segundo Almeida (2002), apresentam uma série de hierarquias sociais que são separadas pela conquista de bens de consumo e simbólicos feita pelos personagens e que organiza essa estrutura social de classes, gênero, raça, geração e possibilidade de consumo.

A narrativa, os personagens e estilos de vida transmitidos por esses programas são uma fonte inesgotável de informações referentes a práticas culturais e representações que estão em circulação na sociedade. Almeida (2002), em sua pesquisa, ressalta que é possível perceber a disputa entre o tradicional e o moderno nas observações feitas entre os entrevistados, mas esse contato com a telenovela permitiu a valorização de padrões que eram tidos como modernos, como a apreciação do trabalho e da independência das mulheres, a aproximação entre pais e filhos e a relação mais igualitária entre homens e mulheres, principalmente quanto à divisão dos afazeres domésticos. 
Almeida (2002) recorre a Giddens (1991) para explicar que a modernidade permite a feminilização dos universos sociais por meio de uma família centrada no amor materno e não no poder patriarcal. Nesse sentido, a autora destaca que esses valores crescem a partir de uma produção cultural como os romances e as telenovelas, que são destinados ao público feminino e focam as suas narrativas nas heroínas femininas e no amor romântico.

Segundo Ortiz (1989), Ortiz, Ramos e Borelli (1989) e Almeida (2002), as telenovelas são narrativas criadas para o público feminino com o objetivo mercadológico. Como as mulheres são consideradas as principais consumidoras de produtos para o cuidado com o lar, de eletrodomésticos e de bens relacionados à moda, as narrativas televisivas são destinadas a esse público - que era responsável pelos afazeres domésticos - que iria consumir tanto os programas quanto os produtos.

Para Távola (1996), naquele período, o pensamento contemporâneo se constituía em dois polos: as pessoas idolatravam ou deificavam a televisão. E essa atitude se iniciou a partir do hábito de se conviver em família com os programas de televisão diários. Ele ainda considera que o fato de a televisão ter se tornado "familiar" retira o mistério da aparição mágica desse meio. Além disso, Távola (1996) aponta que a televisão retira a densidade presente em outras formas de arte as quais não estão presentes nos lares e que o público recebe com expectativa para provar o porquê de elas não estarem presentes nos lares, não serem acessíveis, familiares e domesticadas. O autor mostra que a televisão ser familiar ao público faz com que os seus programas recebam menos reconhecimento do que as artes que não se pode acessar em casa; assim, o público precisa fazer um esforço e um sacrifício para merecê-las, ao contrário do que a televisão propõe.

O autor destaca que as telenovelas não possuíam uma dimensão reflexiva aflorada, a preocupação era sobre o padrão de produção e não sobre um conteúdo de valor. Contudo, destacamos que essa situação não se estende aos programas exibidos posterirormente, sobretudo nas produções do século XXI. A autora Bárbara Torisu Lemos (2020) aponta que as telenovelas são objetos de estudo na área de comunicação e que, no recorte feito, foi no ano de 2015 que houve as primeiras publicações com a interface entre comunicação e o estudo de gênero, que resultam nas análises sobre a representação feminina nas telenovelas. Nesse sentido, destacamos a mudança da percepção da telenovela como um objeto de pesquisa e o desenvolvimento do olhar crítico que os pesquisadores brasileiros estão desenvolvendo sobre as ficções seriadas e seus reflexos na sociedade. 


\subsection{AS TELENOVELAS DAS SEIS}

Para Ortiz, Ramos e Borelli (1989), a TV Globo é a emissora mais regular e mostrou maior racionalização de planejamento, mantendo sempre suas telenovelas (19, 20 e 22 horas). Testaram inicialmente o horário das 18 horas em 1972; mas é somente em 1975 que ela fixa esse horário e dá início a um período em que sustenta quatro novelas no ar, até extinguir, em 1979, o horário das 22 horas (a última produção foi Sinal de Alerta, de Dias Gomes). Já a Tupi apresenta irregularidades e mexeu constantemente nos horários das 20 horas e 30 minutos e 21 horas.

Os autores comentam que as novelas literárias trazem a ideia de uma recuperação do passado, de raízes e tradição, ou seja, o resgate de uma brasilidade que seria repassada para o telespectador por meio de obras que apresentavam como enfoque diferentes momentos históricos. Para Cristina Brandão e Guilherme Moreira Fernandes (2012), os autores de telenovelas incorporaram ao longo dos anos as demandas sociais e simbólicas do seu público, que em boa parte tem acesso aos bens culturais pela televisão.

Brandão e Fernandes (2012) esclarecem que a Rede Globo destinou quatro faixas de horários para as telenovelas, sendo que, às 18 horas, as ficções seriadas tinham como principal abordagem as adaptações literárias e telenovelas rurais; às 19 horas são romances leves e depois de novela comédia; às 20 horas são exibidos os melodramas modernizados; e às $22 \mathrm{~h}$, as novelas com maiores inovações estéticas e criadas por autores mais eruditos. Eles reiteram que a faixa das seis horas era para adaptações de célebres romances da literatura brasileira, como Senhora, Escrava Isaura e A Moreninha, "além de novelas adaptadas e de telenovelas rurais de Benedito Ruy Barbosa, no horário das 18 horas são exibidos alguns remakes e telenovelas de caráter histórico e/ou narradas no tempo passado" (BRANDÃO; FERNANDES, 2012, p. 34).

Ortiz, Ramos e Borelli (1989) apresentam que o Governo Castelo Branco tinha uma preocupação com o desenvolvimento da cultura brasileira e da identidade nacional. A reprodução dessas obras pode contribuir para reforçar a história do país. Já Ortiz (2001) afirma que, no período militar, as peças teatrais, filmes e livros foram censurados, porém o teatro, o cinema ou a indústria editorial não sofreram censura. Dessa forma, esse momento foi marcado pela repressão ideológica e política, mas também houve a maior produção e divulgação de bens culturais que foram transmitidos, principalmente, pela televisão, pois esse governo reconhecia que os meios de comunicação contribuem para "criar estados emocionais coletivos" (ORTIZ, 2001, p. 116). Essa 
característica de exibir telenovelas de época permanece até os dias atuais, e para o desenvolvimento desse trabalho, optamos por estudar a telenovela Orgulho e Paixão, que faz uma mistura de narrativa histórica e inspiração nas obras literárias da escritora inglesa Jane Austen. 


\section{UMA NOVELA DE ÉPOCA CONTEMPORÂNEA: O FEMINISMO EM UMA NARRATIVA FICCIONAL DA DÉCADA DE 1920}

Veiculada na televisão aberta brasileira (TV Globo) entre os meses de março e setembro de 2018, a telenovela Orgulho e Paixão foi livremente inspirada nos romances de Jane Austen. A trama da novela das seis se passa no início do século XX, no fictício do Vale do Café, que fica localizado no interior de São Paulo.

A telenovela foi escrita por Marcos Bernstein e contou com a direção artística de Fred Mayrink. A personagem principal é Elisabeta (Nathália Dill), a primeira filha da Ofélia (Vera Holtz) e do Felisberto Benedito (Tato Gabus Mendes). A família Benedito é composta de cinco filhas, Elisabeta, Jane (Pamela Tomé), Mariana (Chandelly Braz), Cecília (Anaju Dorigon) e Lídia (Bruna Griphão). A intenção da Dona Ofélia é fazer com que todas se casem, conforme o que a sociedade esperava para as mulheres (D'INCAO, 2004).

A trama também carrega consigo as questões do melodrama. Orgulho e Paixão aborda a temática do romance entre Elisabeta e Darcy (Thiago Lacerda), como o casal principal na obra Orgulho e Preconceito de Jane Austen. Tanto no livro quanto na telenovela, Darcy é um homem de caráter e sisudo, o que gera um sentimento de repulsa em Elisabeta, que acredita que ele era um homem muito orgulhoso. Essa impressão sentida pelas duas personagens principais se transforma ao longo da narrativa e se torna um amor romântico, completando a trajetória e expectativa dos telespectadores, segundo aponta Almeida (2002). Em uma matéria ${ }^{11}$ publicada em fevereiro de 2018 no site do Gshow, encontramos informações sobre a telenovela Orgulho e Paixão que conta aos telespectadores que eles vão encontrar questões relacionadas aos costumes da época, a problemas sociais, à luta pela individualidade, a aventuras amorosas e à disputa entre heróis e vilões.

Nilson Xavier (S/D) $)^{12}$ aponta que a Ofélia Benedito realiza qualquer malabarismo para conquistar um bom partido para as suas cinco filhas. Elisabeta não se insere nos padrões impostos pela sua mãe - e que consequentemente vêm de uma construção social na qual ela está inserida. Elisabeta é libertária e carrega uma ousadia natural, como afirma Xavier (S/D.), e pode afastar ou

\footnotetext{
${ }^{11}$ Informações disponíveis em: https://gshow.globo.com/novelas/orgulho-e-paixao/noticia/orgulho-e-paixao-conhecaa-historia-da-nova-novela-das-6.ghtml. Acesso em: 08 jul. 2020.

${ }^{12}$ Nilson Xavier é um estudioso e fã de telenovela e, desde o ano 2000, ele abastece um site em que faz registros de acordo com suas pesquisas sobre as tramas. Todas as informações apresentadas pelo Xavier estão disponíveis em: http://teledramaturgia.com.br/orgulho-e-paixao/. Acesso em: 08 jul. 2020.
} 
encantar os pretendentes. A personagem principal se difere da sua melhor amiga, Ema (Ágatha Moreira), a casamenteira do Vale do Café e neta do Barão de Ouro Verde (Ary Fontoura).

A família da Ema está falida e a chegada de Camilo Bittencourt (Maurício Destri) e Darcy Williamson (Thiago Lacerda) ao vale é motivo de festa e da realização de um sarau de comemoração, tudo organizado por Ema. O que ela não sabia é que a intenção era comprar as terras de plantação de café do Barão de Ouro Verde, seu avô. Segundo Xavier (S/D), Darcy é filho de um industrial inglês, mas é nascido no Brasil, e é sócio da Julieta Bittencourt (Gabriela Duarte), mãe de Camilo, que é uma mulher amargurada. Após a morte do seu marido, ela constrói um império cafeeiro e conquista o título de Rainha do Café. No vale, a função da empresa do Darcy é construir uma ferrovia para escoar a produção de café das terras de Julieta.

Xavier (S/D) apresenta uma fala do autor Marcos Bernstein, que comenta que os personagens de Orgulho e Paixão são inspirados na obra de Jane Austen e de como seria possível levar a linguagem da literatura para a dramaturgia. O ponto de partida foi em Orgulho $e$ Preconceito, no qual o objetivo da mãe é casar as cinco filhas. As personagens Mariana e Cecília foram inspiradas nas obras Razão e Sensibilidade e Abadia de Northanger, Suzana (Alessandra Negrini) veio de Lady Susan, o ambiente da mansão também veio de A Abadia de Northanger e a governanta, Fani (Tammy Di Calafiori) e o suspense vêm de Mansfield Park.

O estilo foi absorvido pelo público, a trama obteve repercussão e a telenovela encerrou com uma média de 21,5 pontos de audiência no Ibope da Grande São Paulo, o que Xavier (S/D) afirma ser um índice esperado para o horário, mesmo que tenha sido inferior às produções Tempo de Amar, que obteve 22,5 pontos, e Novo Mundo, com 24 pontos.

O autor ressalta que a trama de Orgulho e Paixão dialoga com os temas contemporâneos. Por não ter compromisso com a realidade, a telenovela se ambienta na década de 1910, mas o discurso atual esteve presente. Xavier (S/D) afirma ter extrapolado os "limites da época retratada". Bárbara Torisu Lemos (2019) ainda acrescenta que Orgulho e Paixão retrata o período como após a proclamação da República no Brasil e a sua narrativa aborda os temas que são considerados contemporâneos para aquela época. Para Xavier (S/D), o melhor exemplo dessa abordagem foi a personagem Elisabeta, definida como uma mulher à frente do seu tempo, cujas suas falas e atitudes eram de uma mulher contemporânea. 
O pesquisador de teledramaturgia comenta que questões como sororidade, racismo, homossexualidade e preconceito social foram retratadas com um olhar atual. Xavier (S/D) ressalta que Orgulho e Paixão exibiu o primeiro beijo gay no horário das seis da Rede Globo.

[...] a abordagem foi além: didática na medida certa - com destaque para a interpretação dos atores Juliano Laham (Lucino) e Pedro Henrique Müller (Otávio). O drama dos personagens conquistou as redes sociais e a torcida do público - \#Lutavio (XAVIER, S/D, on-line).

Mesmo sendo uma telenovela de época, as discussões abordadas são contemporâneas e é esse embate entre o tradicional e o moderno que é o fio condutor da narrativa da obra.

\subsection{AS PERSONAGENS FEMININAS EM ORGULHO E PAIXÃO}

Como descrito anteriormente, Orgulho e Paixão é uma trama que tem a presença feminina como algo muito marcante na narrativa. Nesse tópico, vamos apresentar mais informações sobre as personagens; todas retiradas do site do Gshow ${ }^{13}$.

Cecília Benedito $^{14}$ (Anaju Dorigon) é a filha mais caseira da família Benedito. Ela gosta de ler e está sempre cercada de livros. Cecília se apaixona por Rômulo, que é um playboy conquistador que parece não ter nada a ver com ela.

Figura 1 - Cecília Benedito

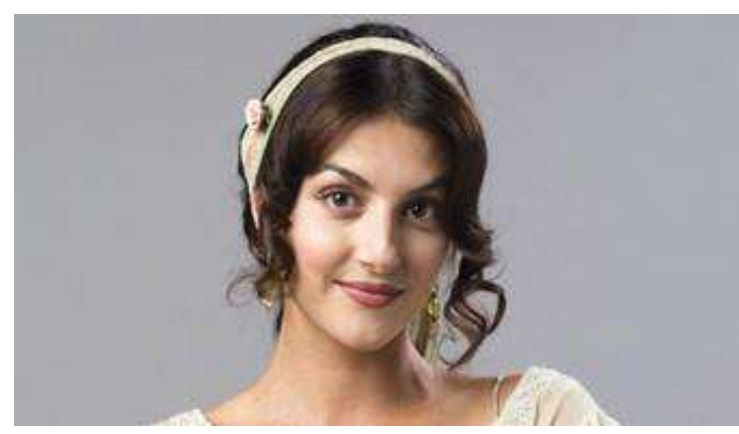

Fonte: Gshow (2018).

\footnotetext{
${ }^{13} \mathrm{O}$ Gshow é o site da Rede Globo com informações referentes aos programas de entretenimento da emissora. No caso de Orgulho e Paixão, as informações estão disponíveis em: https://gshow.globo.com/novelas/orgulho-epaixao/personagem/. Acesso em: 10 jul. 2020.

14 Informações disponíveis em: https:/gshow.globo.com/novelas/orgulho-e-paixao/personagem/cecilia-benedito/. Acesso em 11 de jul. 2020.
} 
Elisabeta Benedito (Nathália Dill) ${ }^{15}$ é filha de Felisberto e Ofélia Benedito e é uma personagem à frente do seu tempo, que rejeita a ideia de se casar por conveniência. Mesmo com as diferenças referentes ao temperamento forte, ela descobre o amor quando conhece Darcy, e essa diferença é um dos principais motores para que o casal lute para viver o amor.

Figura 2 - Elisabeta Benedito

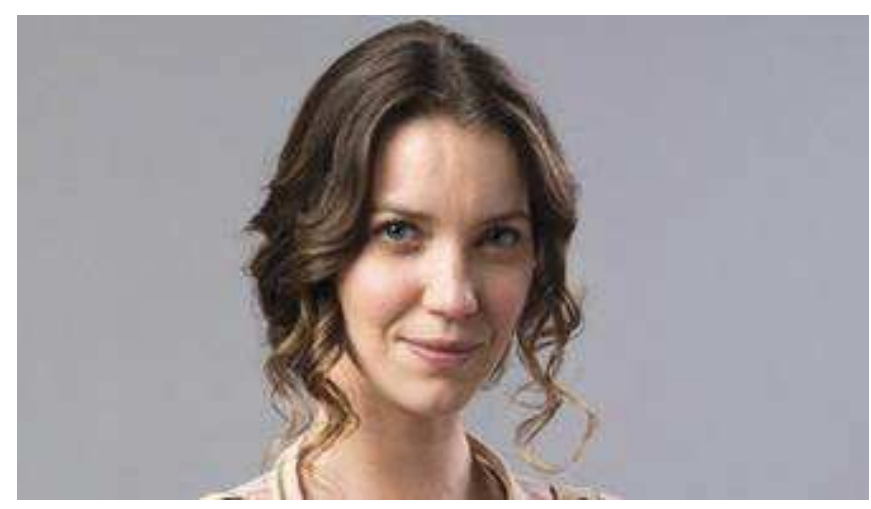

Fonte: Gshow (2018).

Ema Cavalcante ${ }^{16}$ (Ágatha Moreira) é uma jovem alegre, educada, confiante, gentil, linda e leve. Ela é neta do Barão de Ouro Verde, o homem mais rico do Vale do Café e é a melhor amiga da Elisabeta.

Figura 3 - Ema Cavalcante

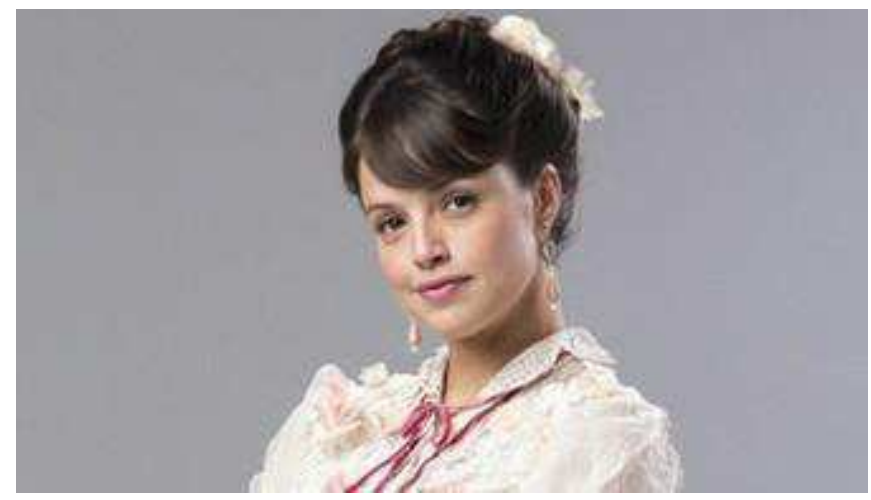

Fonte: Gshow (2018).

\footnotetext{
15 Informações disponíveis em: https://gshow.globo.com/novelas/orgulho-e-paixao/personagem/elisabeta-benedito/. Acesso em: 11 jul. 2020.

16 Informações disponíveis em: https://gshow.globo.com/novelas/orgulho-e-paixao/personagem/ema-cavalcante/. Acesso em: 11 jul. 2020.
} 
Jane Benedito (Pâmela Tomé) ${ }^{17}$ é a segunda filha da família Benedito. Ela é doce e tímida e não faltam pretendentes para ela. Jane é a mais próxima de Elisabeta e sofre muito com as mudanças ocorridas no seu relacionamento com Camilo, mas precisa encontrar forças para ficar com seu grande amor.

\section{Figura 4 - Jane Benedito}

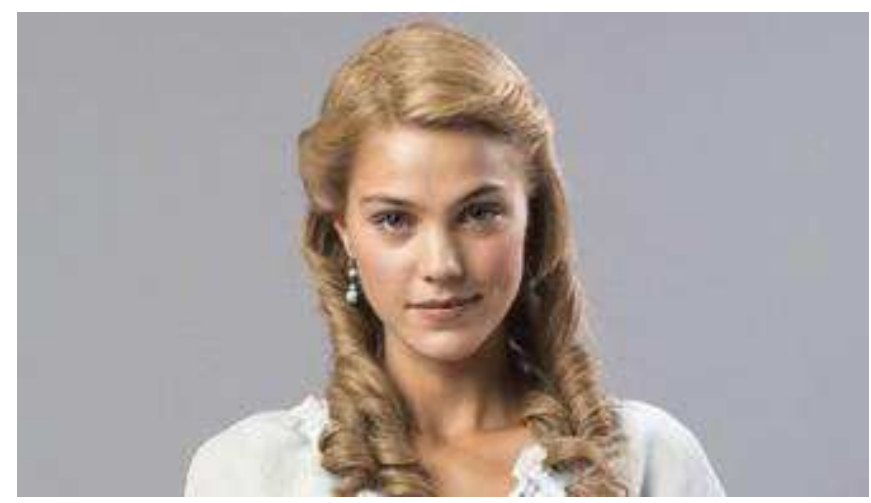

Fonte: Gshow (2018).

Figura 5 - Josephine Tibúrcio

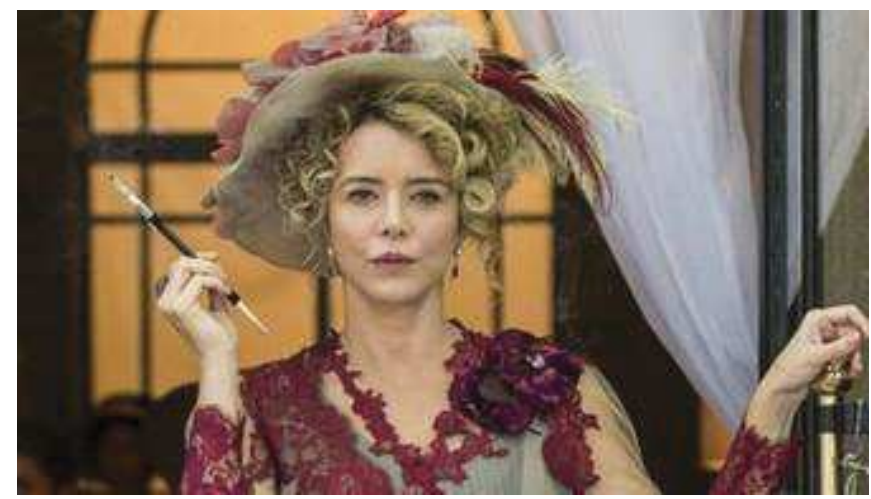

Fonte: Gshow (2018).

Josephine Tibúrcio (Christine Fernandes) ${ }^{18}$ casou com o Almirante Tibúrcio e pertencia à alta sociedade paulista. Ela é culta, viajada e tem um humor fino e uma beleza impressionante. Do seu casamento, vieram dois filhos (Edmundo e Rômulo), mas ela repudiava a autoridade do marido

\footnotetext{
17 Informações disponíveis em: https://gshow.globo.com/novelas/orgulho-e-paixao/personagem/jane-benedito/. Acesso: 11 jul. 2020.

${ }^{18}$ Informações disponíveis em: https://gshow.globo.com/novelas/orgulho-e-paixao/personagem/josephine/. Acesso em: 11 jul. 2020.
} 
e isso a levou a fingir a sua morte. Dez anos depois da suposta morte, ela volta ao Vale do Café e reivindica tudo o que é dela.

Julieta Bittencourt (Gabriela Duarte) ${ }^{19}$ é a rainha do café e se torna uma mulher amargurada depois do seu casamento. Com a morte do esposo, Julieta educa o filho Camilo e constrói o seu império do café. Apesar de amar o seu filho, não demonstra o carinho necessário, e ela não percebe que a Suzana, sua assistente, é uma má influência.

Figura 6 - Julieta Bittencourt

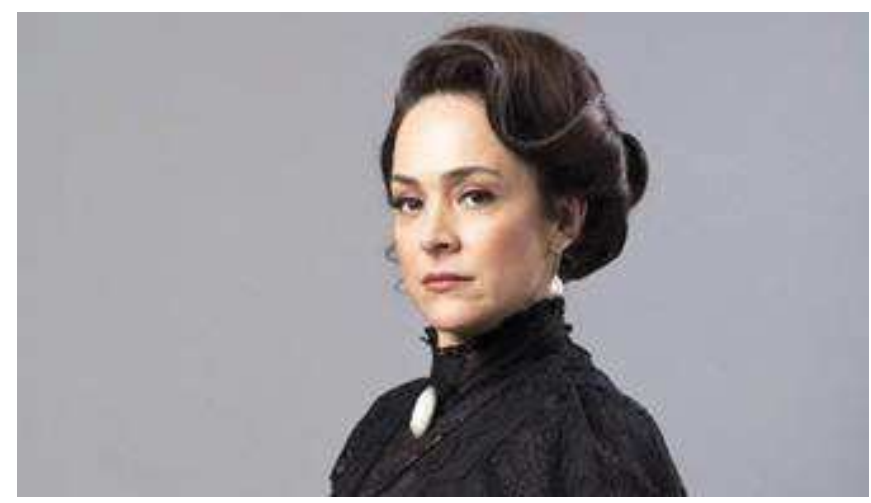

Fonte: Gshow (2018).

Figura 7 - Lídia Benedito

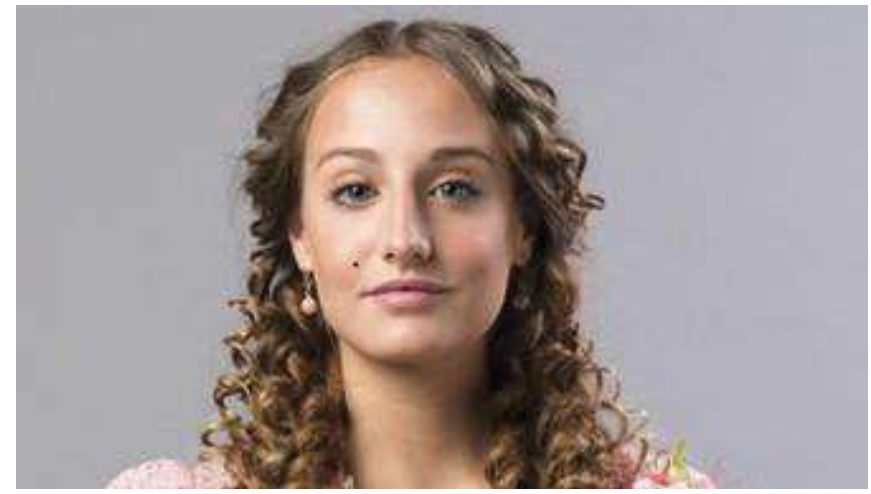

Fonte: Gshow (2018).

${ }^{19}$ Informações disponíveis em: https:/gshow.globo.com/novelas/orgulho-e-paixao/personagem/julieta-bittencourt/. Acesso em: 11 jul. 2020. 
Lídia Benedito (Bruna Griphao) ${ }^{20}$ é a filha caçula da família Benedito. Ela tem uma ingenuidade quase infantil e está sempre nas situações cômicas. Ela é espevitada e sempre consegue escapar das suas escapulidas.

Ludmila de Albuquerque (Laila Zaid) ${ }^{21}$ é uma mulher moderna, viajada, sofisticada, espirituosa, vive na boemia e é além do seu tempo. Ela conhece Elisabeta em um evento e as duas se tornam amigas. Como Ludimila tem os mesmos interesses de Elisabeta, Ema fica com medo de perder a sua amiga.

Figura 8 - Ludmila de Albuquerque

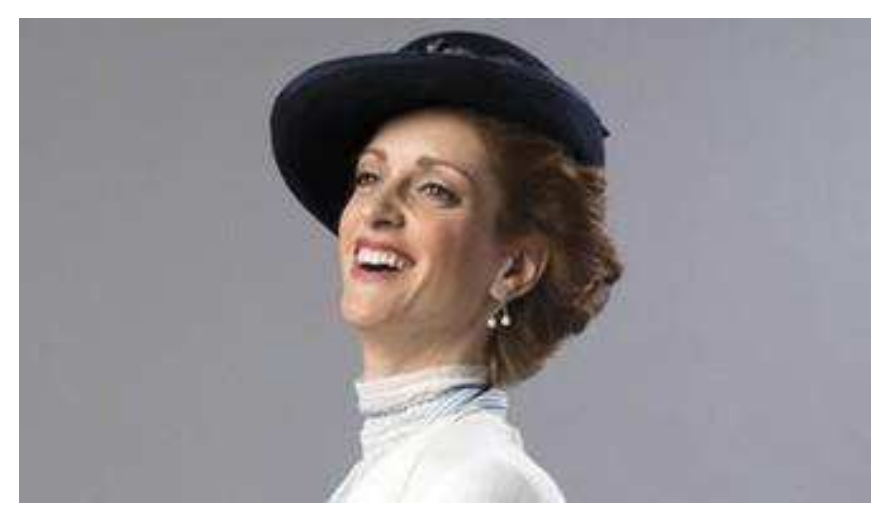

Fonte: Gshow (2018).

Figura 9 - Mariana Benedito

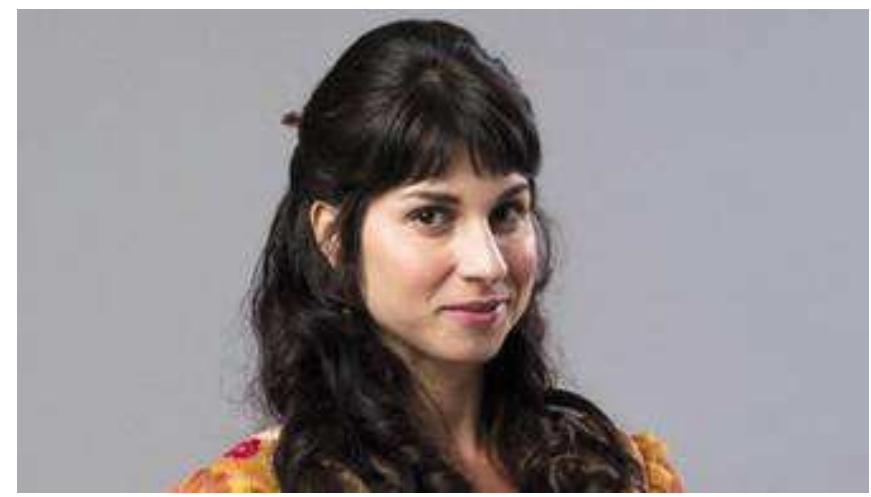

Fonte: Gshow (2018).

20 Informações disponíveis em: https://gshow.globo.com/novelas/orgulho-e-paixao/personagem/lidia-benedito/. Acesso: 11 jul. 2020.

${ }^{21}$ Informações disponíveis em: https://gshow.globo.com/novelas/orgulho-e-paixao/personagem/ludmila-dealbuquerque/. Acesso em: 11 jul. 2020. 
Mariana Benedito (Chandelly Braz) ${ }^{22}$ é uma das cinco filhas da Ofélia e do Felisberto Benedito. Mariana é radical e sempre busca por um amor que seja forte e explosivo. Ela se envolve com Diogo Uirapuru, que é um poeta que leva a vida sem regras e rejeita o coronel Brandão, um homem por quem ela tem carinho, mas que é entediante.

Mariko (Jacqueline Sato) ${ }^{23}$ é médica e descendente dos primeiros japoneses que chegaram ao Brasil. O bisavô de Mariko seguia a medicina tradicional oriental, casou-se com uma brasileira e se estabeleceu no sul do país. Como descendente desse pioneiro, Mariko foi longe e se tornou uma das primeiras mulheres a se graduar em Medicina na faculdade de Porto Alegre. O preconceito sofrido por ser mulher e descendente de oriental fez com que Mariko se mudasse para São Paulo e vivesse no cortiço, que é onde ela conhece Januário e os outros personagens da trama.

\section{Figura 10 - Mariko}

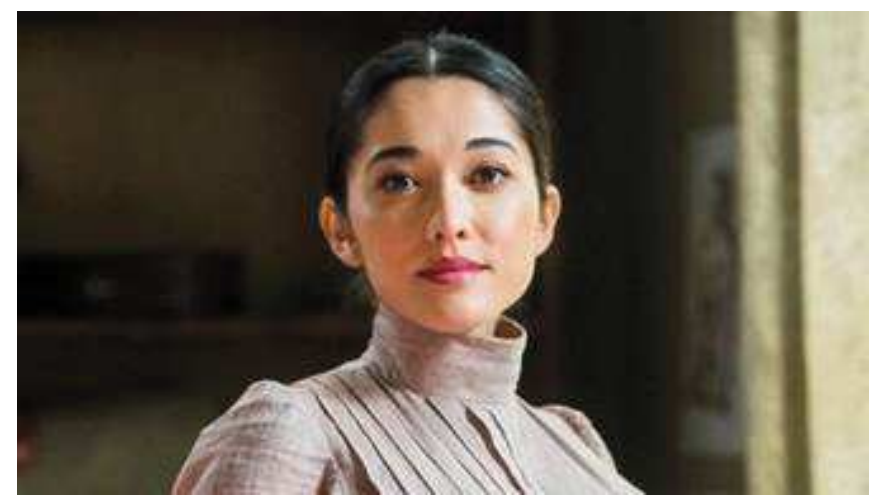

Fonte: Gshow (2018).

Ofélia Benedito ${ }^{24}$ é a matriarca da família e a sua única missão de vida é casar as suas cinco filhas com bons pretendentes. Ela sempre fica pensando no casamento das filhas, o que muitas vezes é a contragosto do marido, Felisberto.

\footnotetext{
22 Informações disponíveis em: https://gshow.globo.com/novelas/orgulho-e-paixao/personagem/mariana-benedito/. Acesso em: 11 jul. 2020.

${ }^{23}$ Informações disponíveis em: https://gshow.globo.com/novelas/orgulho-e-paixao/personagem/mariko/. Acesso em: 11 jul. 2020.

24 Informações disponíveis em: https:/gshow.globo.com/novelas/orgulho-e-paixao/personagem/ofelia-benedito/. Acesso em: 11 jul. 2020.
} 
Figura 11 - Dona Ofélia

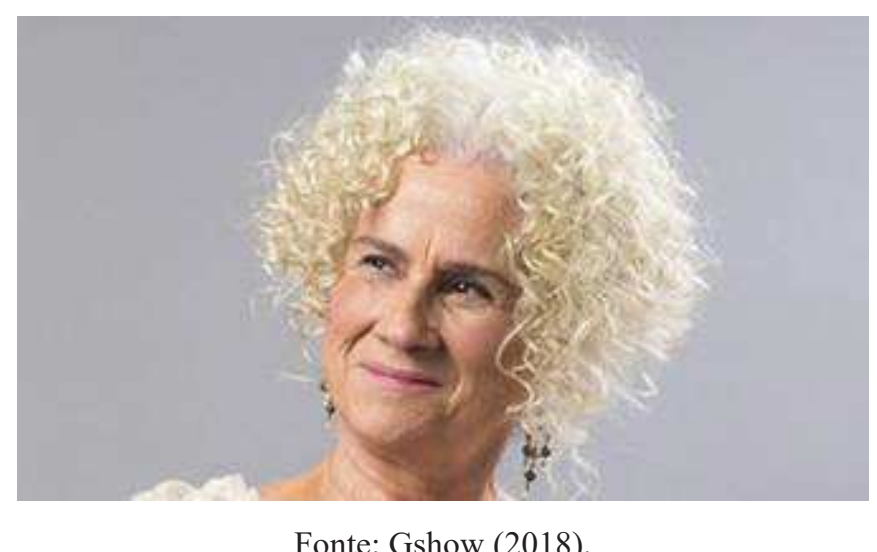

Fonte: Gshow (2018).

Xavier (S/D) comenta que a liberdade sexual das personagens femininas fez com que o roteiro fosse considerado amoral para a época na qual a trama se passava e como é uma narrativa ficcional, o autor destaca que a trama assumiu um compromisso com a atualidade e não é um documentário sobre como as mulheres se comportavam no início do século XX.

\subsection{ELIZABETA: UMA REPRESENTAÇÃO DE UM TIPO DE IDENTIDADE FEMININA}

Ondina Fachel Leal (1986) esclarece que as telenovelas são programas da indústria cultural e, nesse sentido, elas são criadas com o objetivo de produzir conteúdo para um público massivo. Esse tipo de produção, segundo a autora, é composto de produções que contam com um grande investimento de capital e emprego técnico, de forma que os produtos (telenovelas, curta-metragens e séries) conquistaram um mercado significativo fora do Brasil - "a televisão (a emissão televisiva ocupa grande parte do tempo de não trabalho das classes populares e é um dos lazeres fundamentais em outros segmentos sociais" (LEAL, 1986, p. 13). Para Leal (1986), a telenovela é um bem simbólico e que é pautado nos signos dominantes.

[...] tomo uma novela das oito, que além de uma mensagem abordada e veiculada pelos meios de comunicação de massa em uma sociedade de classes, mensagem está calcada em signos de domínio, buscou entendê-las, sobretudo, como um bem simbólico elaborado na função do grupo dominante e reelaborado por todos os grupos sociais (LEAL, 1986, p. 14 - grifos da autora). 
Com base nessa percepção de que as telenovelas são passíveis de construir referências para a população, percebemos que a representação da Elisabeta é construída para fazer com que ela seja uma mulher à frente do seu tempo. A personagem aspira um futuro diferente do que era previsto para as mulheres da sua cidade e seu século; ela almejava a liberdade e a independência que se configurou no trabalho que ela conquistou. As representações propostas pelos personagens são como bens simbólicos, e Leal (1986) afirma que a noção de bem simbólico, baseada na definição de Bourdieu, determina esse tipo de bem como sendo relativo a alguma esfera de produção que não é necessariamente a econômica, política ou religiosa.

Os bens simbólicos se referem a um campo autônomo e à indústria cultural. Assim, a autora também delimita que a indústria cultural, com base na Escola de Frankfurt, consiste em uma empresa capitalista que produz mercadoria e reproduz capital, que racionaliza a produção, realiza a divisão do trabalho e visa o lucro. Nesse sentido, Leal (1986) explica que cada grupo possui o seu próprio sistema de entendimento, que é baseado na sua história, na sua cultura e na sua representação simbólica.

Além disso, as relações simbólicas são como a articulação entre os campos das relações de classe e como instrumentos de poder e dominação, de forma que o campo simbólico realiza a reprodução do campo das relações de produções sociais. Leal (1986) afirma que os sistemas simbólicos têm como função a ordenação lógica e de fazer a representação do mundo, que assume um papel político de legitimação das hierarquias sociais em uma sociedade de classes. Para a autora, a cultura e a ideologia se interligam e os bens culturais adquirem a função ideológica de realizar a manutenção e a mistificação das relações de dominação.

Ela usa como referência Mattelart e Piccini (1977) para afirmar que é a partir da vivência, do acesso às referências e da experimentação que os setores populares criam sentidos para os objetos culturais burgueses. Isso faz com que a leitura promovida por esses sujeitos das classes populares seja feita de forma particular, e não uma leitura universal.

Acabam por concluir que a cultura popular é a cultura de conteúdo transformador, é a cultura politizada e que deve utilizar o meio, no caso, a televisão, que é democrático por excelência, e transformar sua mensagem, que funcionará então como aspecto (ideológico) transformador (da ordem ideológica) (LEAL, 1986, p. 23). 
A partir do final dos anos 1960, Hamburger (1998) afirma que, seguindo o modelo proposto na Tupi, as novelas da Rede Globo se contrapuseram ao estilo "fantasioso" que dominava a produção que era feita anteriormente e propôs uma alternativa "realista". Nessa perspectiva, Almeida (2002) comenta que a novela mostra aos espectadores mundos e situações que são diferentes daquilo que eles próprios vivem e, ao fazer isso, eles começam a se familiarizar com esses mundos que, a princípio, são distantes do seu.

Almeida (2002) diz que tratar de sentimentos humanos, como o amor romântico e os conflitos na família, que são considerados pelos telespectadores como "universais, faz com que as telenovelas sejam consideradas histórias verdadeiras e realistas, ao mesmo tempo que esse programa é considerado como fantasioso. Tendo alcançado a posição de principal produto da indústria de proporções respeitáveis, Hamburger (1998) apresenta que a novela se tornou um dos principais espaços de problematização do Brasil e das intimidades que são do âmbito privado até as políticas públicas.

A ideia de que Elisabeta representa uma mulher à frente do seu tempo vem sendo construída na narrativa da própria telenovela desde as chamadas do programa, que diz: “'Orgulho e Paixão': em uma época cheia de regras, elas seguiam as delas". A chamada se inicia com a seguinte fala: "em um tempo em que as mulheres eram criadas para serem donas de casa... Elas eram donas do próprio nariz. Em uma época cheia de regras, elas seguiam as delas. Vem aí, Orgulho e Paixão". Ao todo, seis chamadas (com as cinco irmãs Benedito e Ema) foram transmitidas e todas afirmavam que as mulheres viviam nessa época cheia de regras, mas que foram elas mesmas que criaram as normas sociais que as permitiam viver naquele tempo.

$\mathrm{Na}$ própria entrevista com o autor e diretor da trama, Marcos Bernstein, publicada em fevereiro de $2018^{25}$, este afirma que Elisabeta está à frente do seu tempo. Considerando que a telenovela se passa no início do século XX, uma mulher não tinha oportunidade de conquistar o espaço público ou trabalhar. Buscar por relações mais igualitárias, como propunha Elisabeta, dialoga com os ideais considerados modernos e, ao se passar em um contexto em que as normas sociais eram mais restritas para as mulheres, as atitudes das personagens acabam ficando em destaque. ${ }^{25}$ Matéria disponível em: $\underline{\text { https://gshow.globo.com/novelas/orgulho-e-paixao/noticia/orgulho-e-paixao-conheca-a- }}$
historia-da-nova-novela-das-6.ghtml. Acesso em: 13 jul. 2020 . 
Durante toda a narrativa, Elisabeta tem seus conflitos de ordem familiar, nas amizades e no relacionamento amoroso, no qual a disputa sempre está de acordo com os seus interesses pessoais e os deveres das mulheres. As disputas começam dentro de casa, quando a personagem demonstra seu desinteresse em casar-se, mas sim em conquistar o mundo. No diário em vídeo e on-line ${ }^{26}$, publicado no Gshow, Elisabeta revela que gosta de deixar claro o que ela pensa e que seu figurino no baile surpreendeu muitas pessoas. A roupa escolhida pela personagem foi uma roupa masculina, com calça, que não era usual para mulheres naquela época. A personagem também revela que o homem que ela encontrou na loja de roupas masculinas, quando ela foi comprar a peça do vestuário para o baile, era muito arrogante, e o universo conspira para os dois se encontrarem.

Elisabeta demonstra ser uma mulher com desejos diferentes do seu tempo por meio das atitudes que ela tem com quem está à sua volta. Em alguns momentos, ela não é vista com bons olhos, pois se recusa a seguir os padrões de vida destinados às mulheres daquele período, embates que são muito percebidos quando ela se relaciona com Dona Ofélia ou Ema Cavalcante. Por outro lado, esse pensamento mais moderno já se torna mais compatível com o de Ludmila Albuquerque, que é uma burguesa de São Paulo. Podemos perceber que, além Elisabeta possuir desejos diferentes dos de outras meninas do Vale do Café, que sonham se casar, a personagem busca conquistar outros espaços na sociedade; tais embates são percebidos por meio dos relacionamentos da personagem dentro da trama, o que nos permite estudar como eles acontecem. Nessa perspectiva, as telenovelas surgem como um intermediador entre a população e essas discussões contemporâneas, como o feminismo.

26 Diário disponível em: https://gshow.globo.com/novelas/orgulho-e-paixao/playlist/diarios-de-orgulho-epaixao.ghtml. Acesso em: 14 jul. 2020. 


\section{ANALISANDO A MATERIALIDADE AUDIOVISUAL DE ORGULHO E PAIXÃO}

Como um produto audiovisual, a telenovela requer uma metodologia que contemple todas as esferas e elementos que compõem esse tipo de material. Neste capítulo, apresentamos a metodologia escolhida para análise deste trabalho, que é a Análise da Materialidade Audiovisual, a aplicação da metodologia e o desenvolvimento e aplicação da ficha de análise nos trechos selecionados.

Após a realização desse trajeto, desenvolvemos nove gráficos em que apresentamos os dados encontrados nas fichas de análise, realizamos a sua interpretação e apresentamos situações marcantes analisadas para exemplificar as situações.

\subsection{COMO ESTUDAR PROGRAMAS DE TELEVISÃO CONTEMPLANDO TODAS AS ESFERAS DO AUDIOVISUAL?}

Um dos desafios dos estudos dos produtos audiovisuais é analisá-lo sem que seja feita a sua decomposição que descaracteriza a experiência que o telespectador terá ao assistir a esse programa. Com relação aos estudos do telejornalismo, a autora Iluska Coutinho (2018) afirma que há o crescimento no número de trabalhos acadêmicos sobre essa temática, mas existe uma reflexão sobre a investigação dos métodos e técnicas de estudo desse programa.

No estudo dos programas de audiovisual propostos pela autora, a investigação evidencia as técnicas, o enquadramento da gravação, a atitude vigilante e o ceticismo metodológico como forma legitimar o conhecimento que é produzido pelo telejornalismo. Coutinho (2018) afirma que o estudo consiste no uso de técnicas que estão associadas à decupagem e análise de conteúdo para evidenciar os resultados das análises de telejornais que permitissem perceber a existência de uma dramaturgia do telejornalismo, com uma estrutura narrativa dramática dos telejornais que é acompanhada pelos telespectadores ao assistirem as notícias nacionais como um drama cotidiano.

Segundo a autora, a estruturação do noticiário televisivo era feita com base nas situaçõesproblemas que se transformavam em motores que impulsionam as ações seguintes, dramas cotidianos que eram exibidos nas edições diárias dos telejornais. Coutinho (2018) afirma que, na tradução do jornalismo audiovisual para a escrita, que é a forma de representação do saber científico, percebeu-se a necessidade de se criar um método para ser chamado de nosso para estudar o telejornalismo em suas múltiplas telas. A autora recorre a Martín-Barbero (1997) para trazer os 
limites que o uso do texto traz para a instância de análise da experiência do audiovisual. Como alternativa para essa análise, Coutinho (2018) apresentou a ficha de leitura ou avaliação integrada como uma forma de responder às questões oriundas dos problemas de pesquisa.

No âmbito das investigações realizadas no NJA (Núcleo de Jornalismo e Audiovisual) às lentes da dramaturgia do telejornalismo se associariam outros efeitos, de imagem, som, experiência e interpretação, acionados conforme os objetivos a desvelar, referências teóricas mobilizadas em cada pesquisa (COUTINHO, 2018, p. 187).

A Análise da Materialidade Audiovisual, segundo Coutinho (2018, p. 187), tem como objeto de avaliação a unidade "texto + som + imagem + tempo + edição", que contempla todos os códigos, elementos e símbolos do audiovisual e sua complexidade. E foi por esses motivos que optamos por essa metodologia nesta dissertação.

\subsection{A ANÁLISE DA MATERIALIDADE AUDIOVISUAL COMO UMA METODOLOGIA PARA O ESTUDO DAS TELENOVELAS}

Coutinho (2018) destaca que a Análise da Materialidade Audiovisual é feita em cinco etapas: a primeira é a identificação do objeto audiovisual e das suas propostas; segunda é a elaboração da ficha de análise; a terceira é o pré-teste do instrumento; a quarta é a pesquisa documental ou definição e obtenção da amostra a ser estudada; e a quinta é a construção de parâmetros de interpretação dos dados e, em alguns casos, de um material de codificação.

Para explicar melhor essas etapas, descreveremos o processo para a realização da análise da materialidade audiovisual. A primeira parte da análise tem como proposta compreender quais são as promessas ou os modos do objeto empírico. Nesse momento, busca-se entender as formas de (auto)apresentação do objeto, que podem ser identificadas pelos enunciados audiovisuais, pela inscrição no canal ou emissora e pela sua posição na programação.

Essa identificação do objeto também envolve o reconhecimento de elementos paratextuais, que a autora nos apresenta como sendo aqueles que se inscrevem em uma determinada materialidade audiovisual ou em produtos que são intermídias e que dialogam com o objeto. Coutinho (2018) destaca que os possíveis paratextos são vinhetas, chamadas para o programa, anúncios feitos em outros suportes, críticas ou comentários realizados por especialistas ou fãs. 
A segunda parte consiste no mapeamento e estabelecimento de eixos ou itens de categoria de avaliação. A autora destaca que esses parâmetros de análise são formulados com base nas questões de pesquisa e no referencial teórico, e é por meio desses eixos de avaliação que os itens são construídos a partir das perguntas feitas ao objeto de pesquisa. Apesar de ser aplicado em estudos referentes ao telejornalismo, Coutinho (2018) afirma que a Análise da Materialidade Audiovisual também pode considerar os processos de difusão em diferentes suportes ou as estratégias de transmissão que são associadas ao telejornalismo ou outro produto audiovisual que é tomado como objeto.

A ficha de análise permite a mensuração de marcadores quantificáveis, que podem ser mensurados a partir de aspectos ou respostas de perguntas fechadas, e dos qualificáveis, que são as respostas mais descritivas. A autora destaca que a análise pode ser utilizada em pesquisas que buscam levantamentos de aspectos e particularidades específicas de determinados produtos ou materialidades jornalísticas audiovisuais ou permite as comparações ou as testagens de modelos que estão relacionados à observação de matrizes culturais ou testagem de modelos ou técnicas do campo do telejornalismo ou de outros gêneros no campo do audiovisual.

A terceira parte da metodologia consiste na realização de um pré-teste para colocar à prova os instrumentos de investigação para identificar a sua capacidade de responder às questões de pesquisa. Coutinho (2018) destaca que é importante garantir a disponibilidade do material a ser analisado para a realização da pesquisa.

A quarta parte é a pesquisa documental, definição e obtenção da amostra de investigação. A autora ressalta que a obtenção, digitalização, armazenamento e sistematização do material audiovisual a ser investigado no Brasil apresenta um desafio. Mesmo as emissoras sendo abertas, o acesso ao acervo da programação audiovisual não é garantido. Dessa forma, é importante destacar as formas de acesso a esses produtos, pois esse processo também participa da forma de direcionamento do olhar do pesquisador.

Os programas de televisão ficam restritos aos sites e demais redes sociais da própria emissora, e isso nos leva a outro ponto de mediação, que é o controle do acesso aos produtos de audiovisual. A validade e pertinência da amostra tem como critério as questões da análise de conteúdo. Após a seleção da quantidade de produtos ou edições a serem analisadas, o pesquisador deve se atentar à representatividade do objeto de investigação, à exaustividade, à disponibilidade, 
à pertinência aos objetos e parâmetros de pesquisa, à periodicidade de produção e à veiculação do material.

A quinta parte consiste na montagem de um material que será utilizado na codificação, que agrupa as possíveis respostas ou situações-problema que podem ser antecipadas após o pré-teste da ficha de avaliação. Coutinho (2018) afirma que é recomendado uma (pré)codificação quando as amostras de pesquisa envolvem um grande volume de material ou mais de um pesquisador.

Para a autora, a análise da materialidade audiovisual é feita como forma de apuração de aspectos constantes em uma pauta, que, nesse caso, é de investigação; assim,

[...] os procedimentos de (pré)produção realizados, a análise se assemelha a uma entrevista com o objeto empírico, que em diálogo com as reflexões teóricometodológicas realizadas, deve ser capaz de responder à questão de pesquisa proposta (COUTINHO, 2018, p. 192).

As telenovelas são programas de televisão exibidos em capítulos diários, que podem ser vistos de segunda a sábado nos canais abertos das emissoras Brasileiras. Orgulho e Paixão foi um programa exibido entre os dias 20 de março a 24 de setembro de 2018, somando 162 capítulos. O objetivo dessa pesquisa é responder: como a telenovela Orgulho e Paixão, por meio da personagem Elisabeta, promove o questionamento sobre os valores determinados para as mulheres no século XX? Qual o paralelo pode ser feito com a sociedade contemporânea? Para realizar esse estudo, resolvemos fazer uma observação sobre todos os capítulos, com a intenção de identificar em quais situações a personagem Elisabeta questiona os valores da época e como esse programa nos ajuda a entender as mulheres do início do século XX.

Para a realização dessa coleta de dados, criamos uma tabela no Google Sheet ${ }^{27}$ que era composta de seis colunas: (1) capítulo e data de exibição; (2) duração da cena; (3) descrição da cena; (4) sinopse do capítulo; (5) número de curtidas; e (6) link da ficha de análise. Essa tabela foi construída com o objetivo de registrar em quais personagens, capítulos e qual a duração das cenas em que havia discussões sobre os costumes e tradições e que reforçaram os lugares das mulheres na época. Essa tabela foi criada em fevereiro de 2020 e concluída em outubro do mesmo ano. Para identificar quais cenas seriam ou não analisadas, buscamos momentos em que a personagem Elisabeta dialogava com algum outro personagem da trama sobre o papel da mulher naquele

\footnotetext{
${ }^{27}$ O Google Sheet é a ferramenta de editar tabela disponibilizada pelo Google.
} 
período, quando ela realizava alguma reflexão sozinha sobre seus desejos e sonhos e até mesmo em algumas atitudes tomadas pela personagem.

Ao longo da coleta de dados, percebemos que, ao observar Elisabeta, deixaríamos de contemplar o posicionamento de outras personagens que também contribuem para a formação dessa identidade da mulher moderna na narrativa da telenovela. A partir dessa percepção, voltamos nosso olhar para as outras personagens mulheres de Orgulho e Paixão, como Cecília, Ema, Jane, Julieta, Ludimila, Mariana, Mariko e Dona Ofélia. Ao final da coleta de dados que envolve todas essas personagens, chegamos ao total de 325 cenas a serem analisadas.

Orgulho e Paixão é uma telenovela que foi exibida no horário das 18 horas. A sua posição dentro da programação e o fato de ser uma telenovela de época faz algumas promessas para os telespectadores. Ortiz, Ramos e Borelli (1989) afirmam que o horário das seis horas da tarde foi testado inicialmente em 1972, mas só passou a exibir telenovelas de forma recorrente a partir de 1975. Seguindo a Política Nacional de Cultura, os autores destacam que o horário das 18 horas foi destinado a adaptações de obras literárias nacionais. Seguindo esta mesma perspectiva, Brandão e Fernandes (2012) destacam que, das quatro faixas de horários para as telenovelas, a de seis horas da tarde ficou destinada a exibir programas que fossem adaptações literárias, rurais, remakes e de caráter histórico ou narradas em tempos passados. Com base nesses autores, percebemos que as principais promessas de Orgulho e Paixão consistem em fazer uma representação de obras literárias, ser uma telenovela rural e que se passa no passado.

Os paratextos analisados para essa pesquisa consistem em seis vídeos, que são as chamadas para a exibição da telenovela. No site do Gshow, elas têm o título de "Orgulho e Paixão": em uma época cheia de regras, elas seguiam as delas $^{28}$ e são vídeos que apresentam as personagens Elisabeta, Ema, Cecília, Jane, Lídia e Mariana com a duração de 15 segundos cada.

O primeiro vídeo tem o título Orgulho e Paixão: conheça Elisabeta e se inicia com a narração da frase "Em um tempo em que as mulheres eram criadas para serem donas de casa [Figura 12], elas eram donas do próprio nariz [Figura 13]". À medida que essas frases são faladas, elas aparecem escritas na tela. Ao final, aparece a imagem da Elisabeta segurando um mapa e a narração continua: "em uma época cheia de regras, elas seguiam as delas [Figura 14]. Vem aí Orgulho e paixão [Figura 15]".

\footnotetext{
28 Vídeos estão disponíveis em: https:/gshow.globo.com/novelas/orgulho-e-paixao/playlist/orgulho-e-paixao-emuma-epoca-cheia-de-regras-elas-seguiam-as-delas.ghtml. Acesso em: 12 nov. 2020.
} 
Figura 12 - Chamada de Orgulho e Paixão

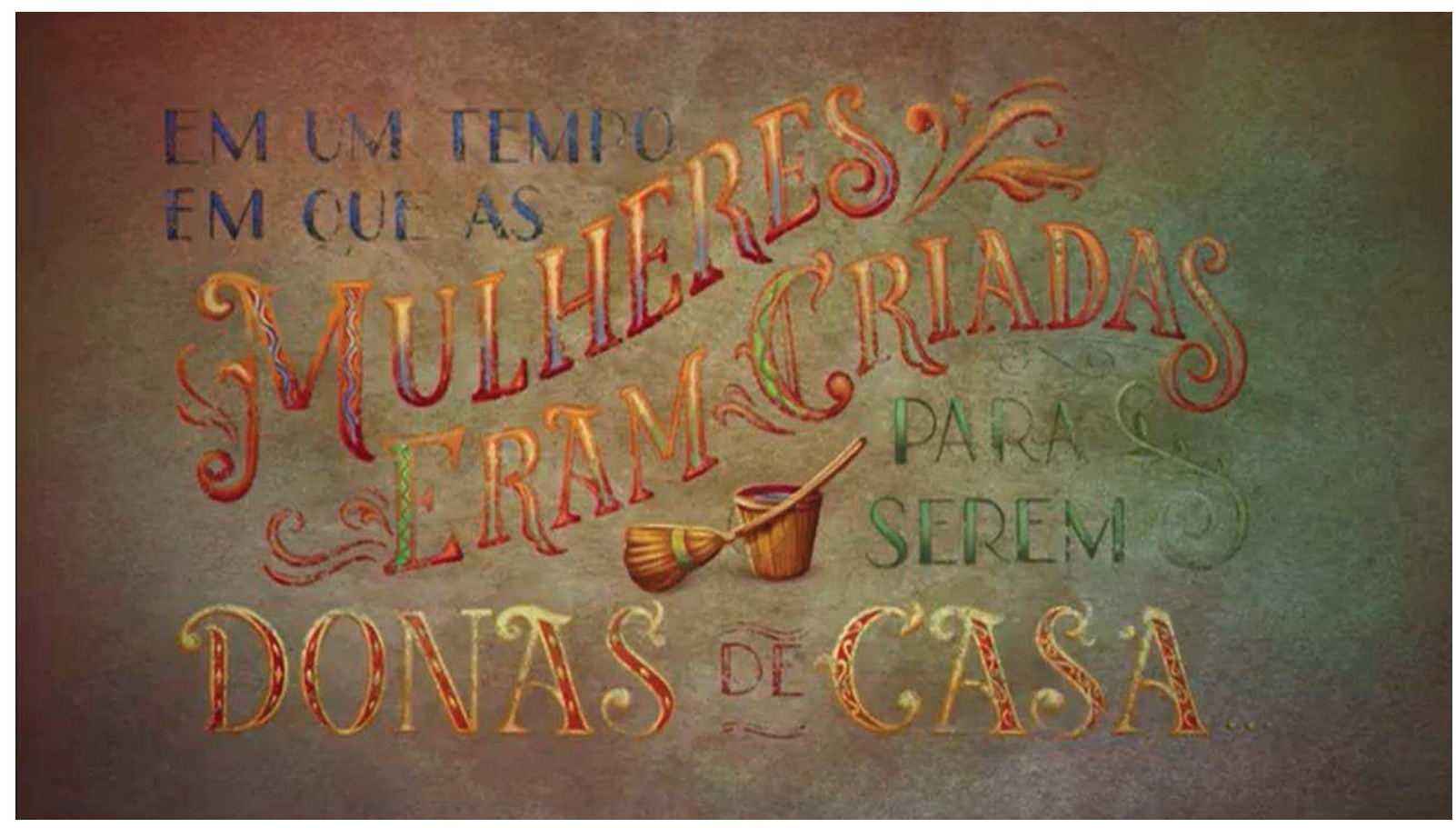

Fonte: print Globoplay (2018).

\section{Figura 13 - Chamada de Orgulho e Paixão}

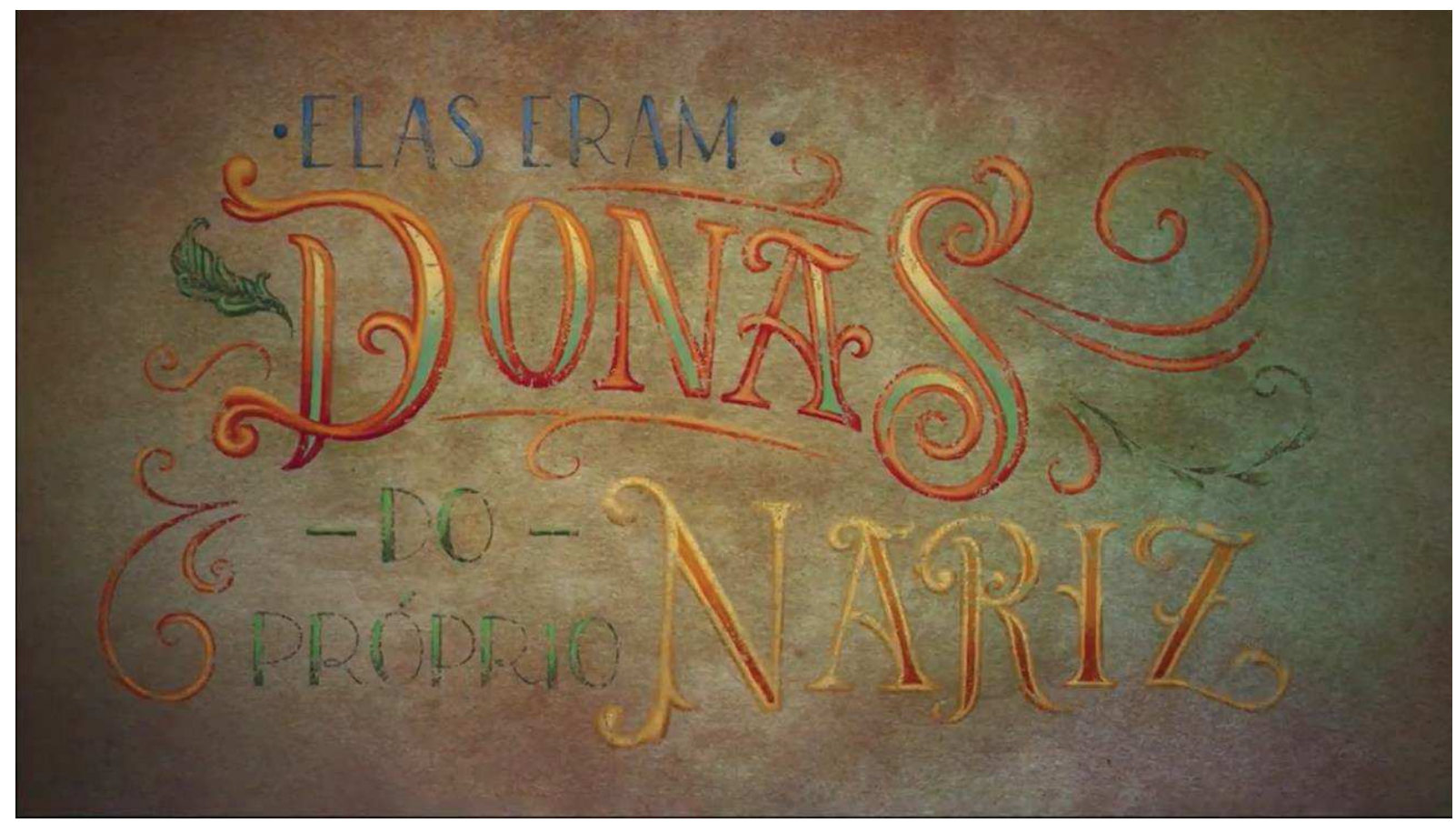

Fonte: print Globoplay (2018). 
Figura 14 - Elisabeta na chamada de Orgulho e Paixão

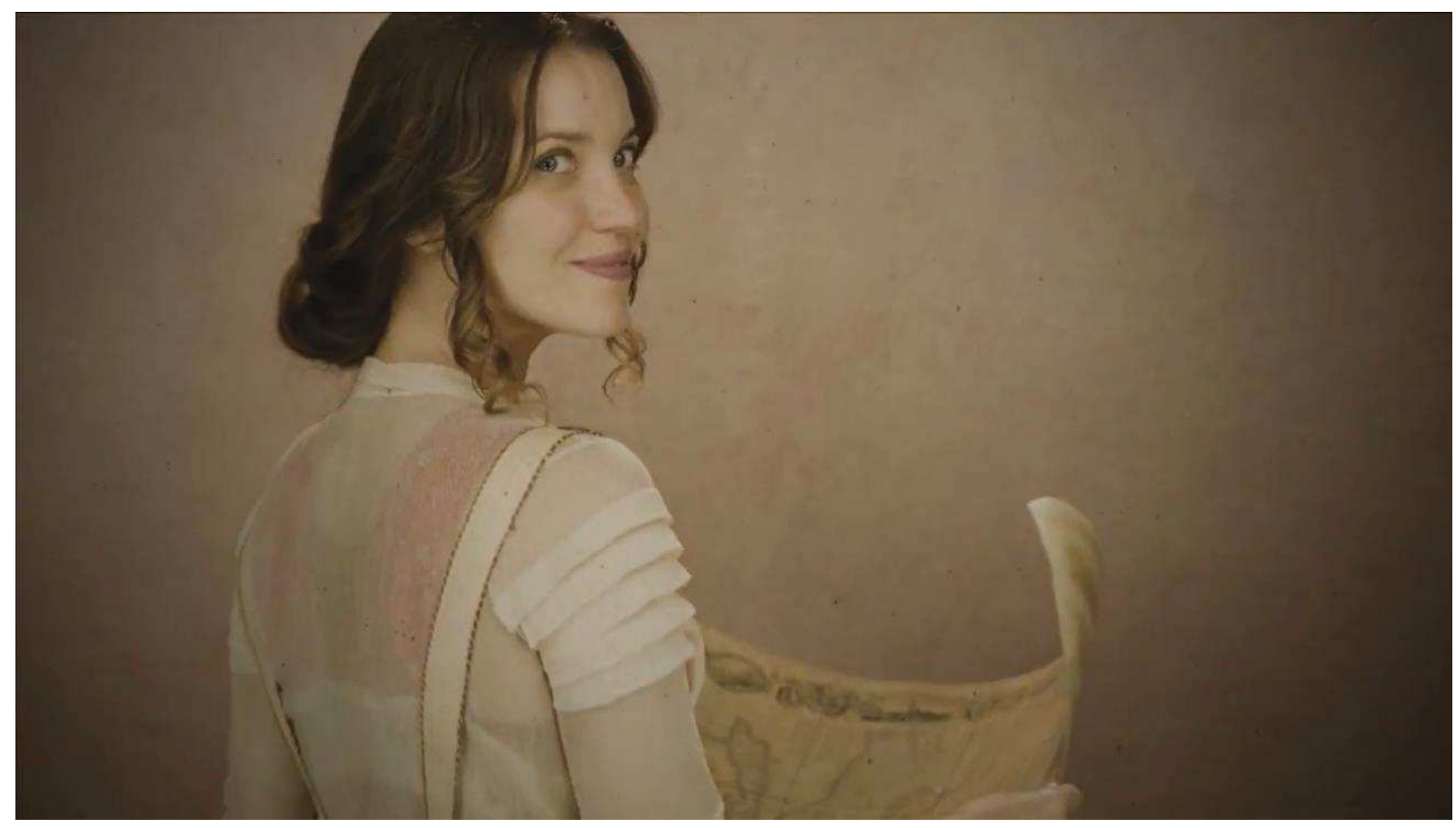

Fonte: print Globoplay (2018).

Figura 15 - Chamada de Orgulho e Paixão

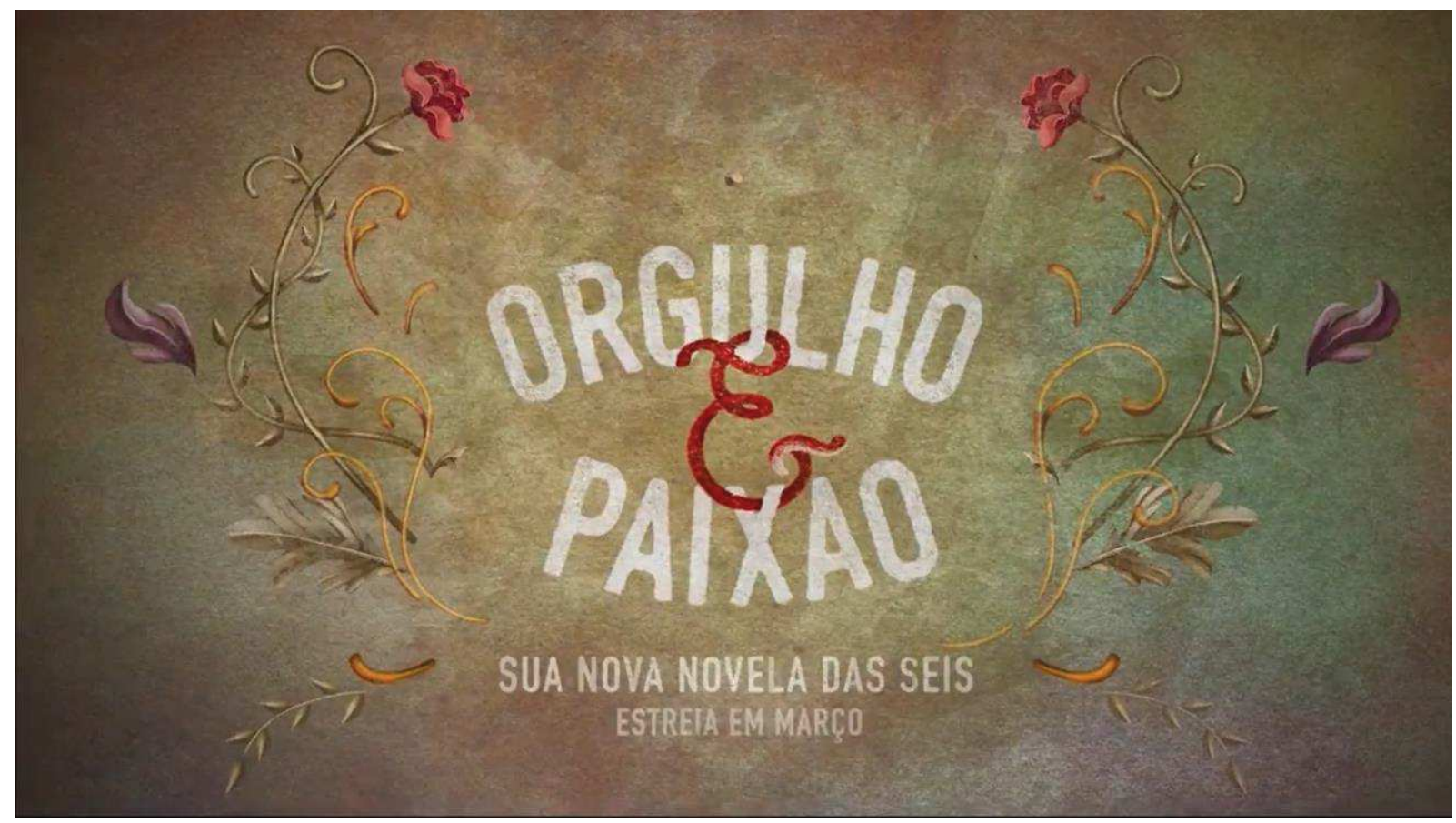

Fonte: print Globoplay (2018). 
O segundo vídeo é a apresentação da personagem Ema, e a frase narrada se altera para "Em um período em que as mulheres tinham que ter boas maneiras, elas tinham boas maneiras de conquistar o que e quem elas queriam. Em uma época cheia de regras, elas seguiam as delas. Vem aí Orgulho e Paixão". Na apresentação do vídeo da Cecília, a frase era a seguinte: "Em um tempo em que as mulheres e reuniam para tomar chá, elas não davam colher de chá para ninguém. Em uma época cheia de regras, elas seguiam as delas. Vem aí Orgulho e Paixão”. No vídeo da apresentação da Jane, a frase era: "Há muitos e muitos anos, as mulheres tinham que saber cozinhar. Elas cozinhavam seus pretendentes. Em uma época cheia de regras, elas seguiam as delas. Vem aí Orgulho e Paixão". No vídeo da Lídia, a frase é: “Há um século, as mulheres aprendiam a pintar e bordar. E pintaram e bordar mesmo. Em uma época cheia de regras, elas seguiam as delas. Vem aí Orgulho e Paixão". No vídeo de Mariana, a frase é: "Em uma era em que as mulheres tinham que saber cantar e tocar. Elas cantavam pneu e tocaram o terror. Em uma época cheia de regras, elas faziam as delas. Vem aí Orgulho e Paixão".

Esses paratextos nos auxiliam a entender um pouco e dar pistas sobre a narrativa da telenovela que ainda não se iniciou. Todos os vídeos seguem o mesmo padrão. As primeiras frases apresentavam obrigações que as mulheres deveriam ter naquele período e o complemento delas sempre mostra que as mulheres tomavam a frente das situações e buscavam fazer o que elas queriam. A terceira frase confirma isso ao dizer que em uma época com muitas regras, elas faziam o que elas queriam. Os vídeos finalizam avisando que Orgulho Paixão estava chegando.

A segunda parte da metodologia consiste na criação de uma ficha de análise com base no referencial teórico utilizado para essa pesquisa. A primeira experiência de ficha de análise para delinear as perguntas direcionadas ao objeto ocorreu em 2019, no artigo produzido para a disciplina Processos Simbólicos e Representações Sociais, ministrada pelo professor doutor Paulo Roberto Figueira Leal, no Programa de Pós-Graduação em Comunicação da Universidade Federal de Juiz de Fora (PPGCOM-UFJF). Neste primeiro momento, a intenção era começar a aplicar o método da Análise da Materialidade Audiovisual em pesquisas de telenovela e, com isso, uma análise de uma cena do primeiro capítulo foi estudada.

Esse esboço de ficha consistia em cinco perguntas que nos ajudariam a entender "qual é o lugar determinado para as mulheres a partir das ações das personagens na telenovela Orgulho e Paixão?". As perguntas feitas foram as seguintes: como é a situação na qual Elisabeta está envolvida? O que está acontecendo? Como o poder simbólico do patriarcado se mostra presente 
nessas cenas? Como Elisabeta reage a esse poder simbólico? Existe a busca por uma saída aos costumes da época? Com quem ela está se relacionando naquele momento?

Essas perguntas tinham como aporte teórico a representação social de Peter Berger e Thomas Luckmann (2004), o patriarcado de Christine Delphy (2009), o poder simbólico do Pierre Bourdieu (2007), a cultura midiática de Douglas Kellner (2001) e a representação da mulher no Brasil de Raquel Soihet (2004). Com a execução deste trabalho, publicamos um artigo em 2019 em que a autora Bárbara Torisu Lemos (2019) concluiu que a Elisabeta era uma mulher que tinha sonhos e desejos diferentes dos das mulheres do século XX. Enquanto Ema acreditava que o casamento é a coisa mais importante da vida de uma mulher, Elisabeta afirma ter outras prioridades.

Esse foi a primeira tentativa de delinear a ficha de análise para o desenvolvimento de uma pesquisa de telenovela com essa metodologia. Ao longo do desenvolvimento da dissertação, coleta de dados, discussões sobre a Análise da Materialidade Audiovisual e orientação com a professora Iluska Coutinho, optamos por desenvolver uma ficha de análise que nos permitisse fazer uma coleta de dados quali-quantitativa do corpo de pesquisa. Ao final, chegamos a esta versão que foi utilizada para analisar as cenas da telenovela:

\section{Quadro 1 - Ficha de análise}

\begin{tabular}{|l|l|}
\hline 1. Número do capítulo & \\
\hline 2. Duração do capítulo & \\
\hline 3. Duração da cena & \\
\hline 4. Qual é a personagem em foco? & $\begin{array}{l}\text { ( ) Sim, presentes e participantes } \\
\text { ( ) Sim, mas são nomeadas. }\end{array}$ \\
\hline ( ) Sim, mas não falam. \\
( ) Não
\end{tabular}




\begin{tabular}{|l|l|}
\hline 8. É conflito ou concordância? & $\begin{array}{l}\text { ( ) Troca de ideias concordante } \\
\text { ( ) Troca de ideias discordantes } \\
\text { ( ) A personagem discorre sozinha. }\end{array}$ \\
\hline 9. Quais papéis são identificados para as mulheres? & $\begin{array}{l}\text { ( ) mãe } \\
\text { ( ) irmã } \\
\text { ( ) esposa }\end{array}$ \\
( ) trabalhadora \\
( ) outro
\end{tabular}

Fonte: Elaboração própria.

A primeira, segunda e terceira questões são de cunho mais descritivo sobre o capítulo e servem como uma forma de identificação das cenas a serem analisadas. A quarta questão apresenta qual personagem está no foco da discussão. A quinta questão é para entender se existem outras mulheres que participam da cena e se há ou não a sua interferência. A sexta pergunta busca entender o foco da discussão, se elas reforçam os valores tradicionais da sociedade, se fazem uma contraposição entre o tradicional e o moderno ou se há apresentação de desejos relacionados à modernidade, que vieram com base nas leituras feitas sobre a história das mulheres no século XX. A sétima questão é para fazer um pequeno resumo do foco da discussão e ser fácil de encontrar na tabela. A oitava pergunta serve para entender se as personagens que fazem parte da discussão concordam ou discordam da narrativa proposta na cena, com base na sexta pergunta. A nona 
questão busca entender qual dos papéis das mulheres são identificados nessa discussão, como mãe, esposa, irmã, trabalhadora ou outro. Esses papéis foram identificados a partir da leitura das autoras Michelle Perrot (2007), Raquel Soihet (2004) e Céli Regina Jardim Pinto (2003). A décima pergunta tem como objetivo entender como essa manifestação ocorreu, se foi por meio de uma conversa e/ou atitude tomada pela personagem. A décima primeira consiste em entender em qual esfera social acontece essa reflexão, se é no espaço público ou no privado. A décima segunda busca entender se nessa situação analisada houve a interseccionalidade na narrativa. A décima terceira foi feita para demonstrar se as personagens que fazem parte da discussão apresentam algum nível de entendimento do motivo pelo qual outra personagem adotou algum discurso ou atitude específica que rompeu com os valores tradicionais ou se essa reflexão acontece enquanto a personagem está sozinha.

Após a análise dos 162 capítulos de Orgulho e Paixão, identificamos 263 situações em que poderíamos perceber a manifestação de discussões relacionadas à posição da mulher naquela sociedade. E, com isso, criamos 263 fichas de análise que nos ajudaram a entender quais são essas situações em que há discussão sobre a representação da mulher na telenovela. A partir de todos os dados que adquirimos após o preenchimento das fichas de análise, os resultados quantitativos foram consolidados por meio de nove gráficos relativos às questões quatro, cinco, seis, oito, nove, dez, onze, doze e treze da ficha.

\subsection{AS PERSONAGENS EM FOCO}

Com base nos dados apresentados no primeiro gráfico (Gráfico 1 - Qual é a personagem em foco?), notamos que Elisabeta foi o foco de 158 cenas analisadas. Depois, temos Mariana, com 25 participações; Julieta, com 23 participações; Ema, com 20 participações; Ludimila, com 18 participações; Charlotte, com 8 participações; Ofélia, Lídia e Mariko, com três participações, e Suzana e Cecília com uma participação. Observamos que a Elisabeta, a personagem principal, é a que tem a maior participação dentro das cenas analisadas. 


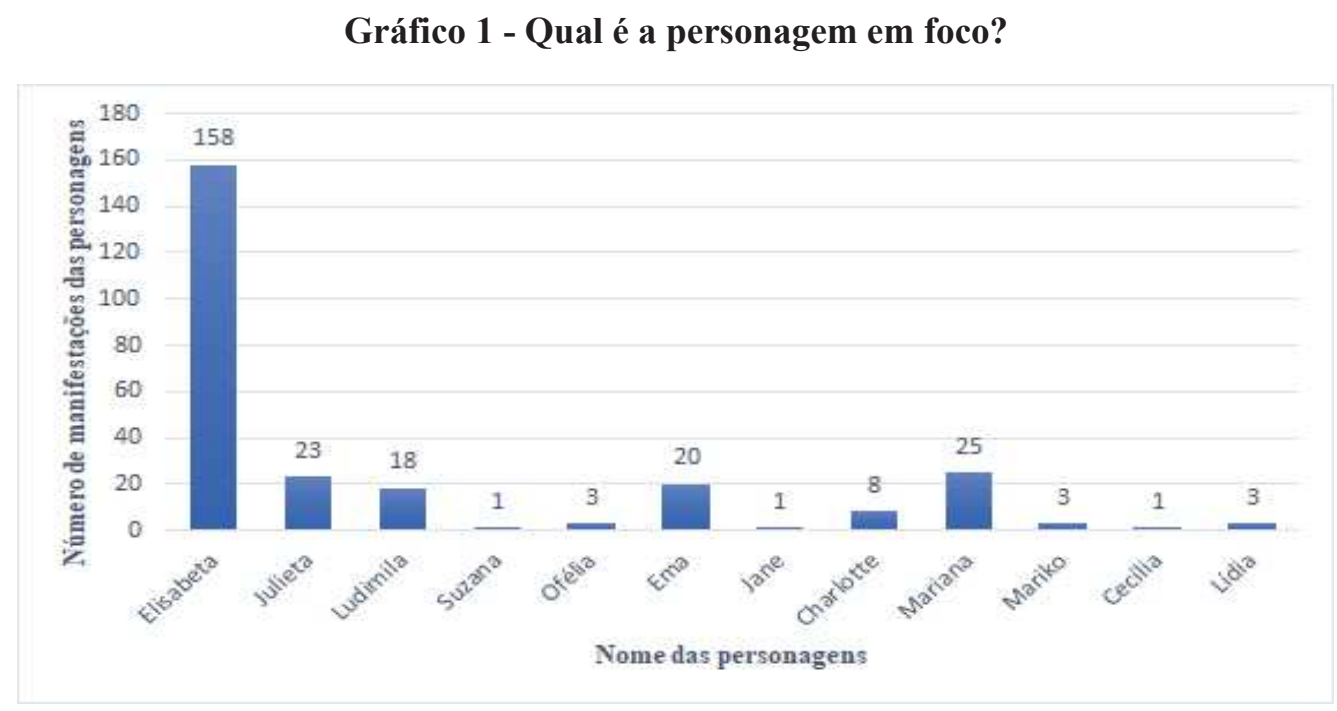

Fonte: Elaboração própria a partir dos dados analisados.

A Elisabeta tem mais destaque em Orgulho e Paixão por ela ser a personagem principal e pelo fato de ela ser a personagem que é considerada pelas outras como uma mulher que está à frente do seu tempo desde o início da exibição da telenovela. A participação dela é decorrente, pois, devido ao seu sonho de viajar, conhecer o mundo e trabalhar, ela acaba participando de diversas discussões dentro da narrativa que a colocavam no foco da conversa. Um dos momentos que podemos destacar da Elisabeta nessa discussão é no primeiro capítulo, quando ela observa um globo e fala que quer conhecer o mundo. No mesmo capítulo, ela chega no baile da cidade vestida como homem e choca a todos que estão presentes, e quando ela conquista seu primeiro emprego na fábrica da família da Ludmila.

Conseguimos perceber que, apesar de a personagem principal ter a maior participação, ela não é a única que tem foco na narrativa da telenovela. Observamos que Mariana, uma das irmãs da Elisabeta, é a segunda personagem que teve destaque em Orgulho e Paixão. A Mariana ganhou notoriedade porque ela se interessou por corridas de motocicleta que aconteciam no Vale do Café, mas ela sabia que esses eventos eram apenas para homens. Esse interesse de Mariana pela velocidade e a motocicleta já foi apresentado na chamada ${ }^{29}$ para a telenovela que foram apresentadas antes da sua estreia. Como forma de participar dessas corridas ilegais, Mariana resolveu se fantasiar de homem e assumiu o nome de Mário para correr. Depois de participar de ${ }^{29}$ Chamada disponível em: https://gshow.globo.com/novelas/orgulho-e-paixao/playlist/orgulho-e-paixao-em-uma-
epoca-cheia-de-regras-elas-seguiam-as-delas.ghtml. Acesso em: $30 \mathrm{dez} .2020$. 
muitas corridas, ela resolveu assumir a sua identidade e os competidores não gostaram de descobrir que havia uma mulher entre eles. Em decorrência disso, Mariana foi sequestrada por Xavier, um fazendeiro e motociclista do Vale, que cortou os seus cabelos para lhe dar uma lição por ela ter se vestido de Mário para enganar os homens que pilotam motocicletas no Vale. Essa passagem de Mariana se torna muito interessante, pois mostra que ela teve que assumir outra identidade para conseguir fazer uma atividade que era considerada masculina. Além disso, no capítulo 127, exibido no dia 14 de agosto de 2018, nos minutos 35:07 a 35:12, aparece uma mensagem ao final da telenovela avisando que violência contra a mulher é crime (Figura 16), que acontece após Mariana sofrer a violência de ter os seus cabelos cortados. A personagem passa por momentos de frustração por acreditar que toda a sua feminilidade estava presente nos seus cabelos.

Figura 16 - Aviso de que violência contra a mulher é filme no capítulo 127, exibido no dia 14 de agosto de 2018

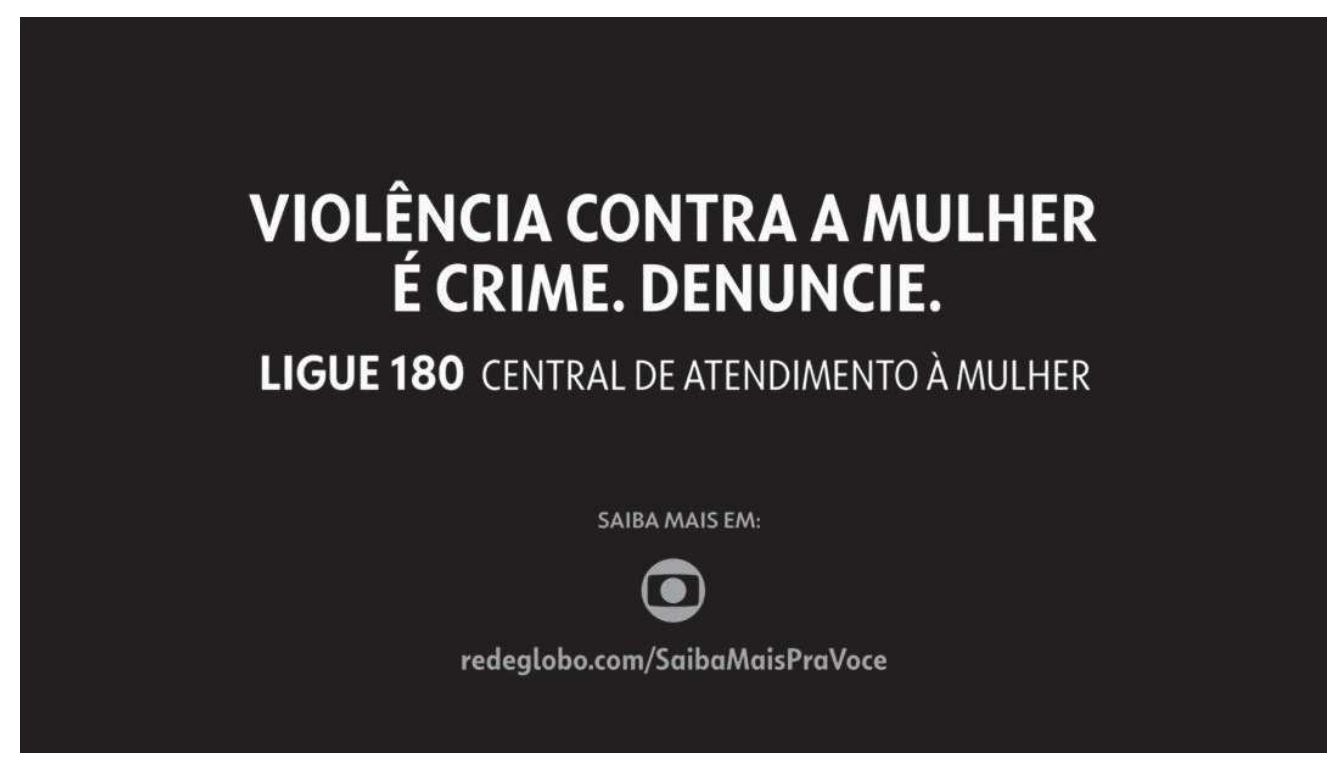

Fonte: print Globoplay (2018).

A terceira personagem que ganha destaque considerando os resultados do primeiro gráfico é a Julieta Bittencourt, chamada de a rainha do café por ter construído um império de produção cafeeira. Julieta é uma mulher rica, que comanda o cultivo de café, mas vive à sombra do seu falecido marido, pois as pessoas acreditam que ela era apenas a herdeira desse império. Destacamos que, ao longo da narrativa, Julieta assume para Elisabeta que foi ela quem construiu o império de café e que ela não herdou tudo de seu marido, como os outros pensam. No capítulo 80, exibido no 
dia 2 de junho de 2018, Julieta afirma que ela é uma fraude, pois todos acreditam que ela é uma viúva afortunada, mas o que restou para ela do seu marido foram apenas dívidas e cobranças. Além disso, a rainha do café afirma que não seria bom para os negócios e que ninguém acreditaria que ela foi a responsável pela administração de sua empresa. Outro ponto importante de se destacar é que Julieta reconhece que ela sofreu uma violência sexual do marido que deu origem ao nascimento do seu filho, Camilo. Nessa discussão, que ocorre no capítulo 81 e exibido no dia 21 de junho de 2018, Elisabeta afirma que esse estupro foi um absurdo e Julieta afirma que ela não tinha nenhuma opção e nada para se fazer naquela época. Assim, percebemos que Julieta assume três papéis importantes na narrativa, o de trabalhadora, o de administradora do seu próprio negócio e o de vítima no reconhecimento da violência que ela sofreu quando jovem.

Ema ficou em quarto lugar como a personagem em foco nas cenas analisadas. Essa figura é muito interessante dentro da telenovela, pois Ema está presente do início ao fim do programa e é a personagem que apresenta maior mudança de visão na narrativa. Ela é a neta do Barão de Ouro Verde e filha do Aurélio Cavalcante, que é considerada a família mais rica do Vale do Café. Ema é uma das representações da visão tradicional em Orgulho e Paixão. Para ela, o principal objetivo das mulheres é se casar com bons partidos e ela se intitula como a casamenteira do Vale por acreditar ser responsável por formar os melhores casais da cidade. Ela é a melhor amiga da Elisabeta e as visões diferentes e opostas são responsáveis pelas maiores discussões entre as duas. Com o decorrer da narrativa, percebemos que Ema é uma das personagens que têm a maior mudança de pensamento. No início da trama, ela reforça que o casamento é o principal destino da mulher e trabalhar e manter o lar é responsabilidade do marido e, com a falência da família, Ema se muda para São Paulo e inicia a sua carreira de vendedora e estilista de moda. E, nesse caminho de descobrimento do seu talento e do trabalho, Ema tem que abrir mão das convenções sociais que foram impostas a ela, como a dependência financeira da família, mas ela busca o casamento arranjado como forma de salvar o nome da sua família.

Ludmila é a quinta personagem de destaque nessa análise, pois ela é a figura que representa a modernidade em Orgulho e Paixão. Ela aparece no capítulo 21, exibido no dia 12 de abril de 2018, e desde o início traz muitas discussões consideradas à frente do tempo das pessoas do Vale do Café. Essa personagem é filha de burgueses que são donos de uma indústria de tecidos em São Paulo. Como Julieta, ela era responsável pela direção do negócio da sua família, no entanto ela não era casada, usava calças, dirigia e empregava mulheres na sua fábrica. A forma de se vestir da 
Ludmila é notada pelas pessoas que a conhecem, pois ela é uma mulher e escolhe de usar calças. Essa questão é abordada nos capítulos 22, 23 e 35 pelos personagens Ema, Darcy e Dona Ofélia. Além disso, Ludmilla afirma que ter filhos não é um dos sonhos dela e que as mulheres podem encontrar a felicidade em outros lugares que não na maternidade.

Charlotte é a sexta personagem em destaque nessa pesquisa e ela tem oito identificações na ficha de análise. Ela é a irmã mais nova de Darcy e ganha destaque nessa narrativa porque ela é alguém que sempre busca a independência e fugir dos cuidados do seu pai e irmão. Charlotte foi enganada por uma paixão que teve quando era mais jovem e acabou se entregando ao Uirapuru, um poeta que se aproveita das mulheres. Depois desse sofrimento e de ter a honra manchada, seu pai e irmão passaram a ter um cuidado excessivo com ela. Ela buscava pela sua independência e quer ser responsável pelas suas próprias decisões. Um dos pontos de virada da personagem foi quando ela começou a trabalhar no jornal que Elisabeta e Venâncio montaram, no capítulo 105, exibido no dia 19 de julho de 2018.

Dona Ofélia é a matriarca da família Benedito e não perde a oportunidade de incentivar as suas filhas a conquistarem um bom casamento. E, nessa discussão, percebemos três momentos em que a personagem se destaca dentro das análises. O primeiro momento ocorreu no capítulo 27 , exibido no dia 19 de abril de 2018, em que ela afirma ser uma péssima mãe por ter enviado Jane à casa dos Bittencourt antes da chuva e por ela ter ficado doente. Ela afirma ser um fracasso como mãe, pois colocou Jane nessa situação e porque ela acha que Elisabeta está perdida. Essa personagem também carrega as marcas da visão tradicional daquele período, e, como Elisabeta tinha aspirações diferentes da mãe, elas tinham discussões discordantes que faziam Ofélia pensar que sua filha estava perdida e não tinha jeito. Um momento que chamamos a atenção é no capítulo 85, do dia 26 de junho de 2018, em que Elisabeta entrevista Dona Ofélia para o jornal em que ela estava trabalhando, e Ofélia reforça a importância das mulheres fazerem bons casamentos e a necessidade dos homens se casarem com mulheres prendadas. Em contrapartida, Felisberto, marido da Ofélia, é um personagem que se mostra mais a favor das ideias e desejos de Elisabeta de viajar e conhecer o mundo.

Mariko é uma personagem que aparece apenas depois que Elisabeta se muda para São Paulo e no momento em que o Camilo precisa de atendimento após se machucar no trabalho. No capítulo 59, exibido no dia 26 de maio de 2018, Elisabeta entrevista a Mariko e pede para ela contar sobre a sua história relacionada à Medicina. Mariko comenta que sua família é de origem japonesa e tem 
experiência com a medicina oriental e que ela é a primeira médica formada da sua família. Elisabeta se anima devido à possibilidade de ela ter se formado em uma instituição de Ensino Superior. As demais inserções de Mariko estão relacionadas com os atendimentos que ela faz a seus pacientes.

Lídia é a filha caçula da família Benedito e se mostra como uma seguidora dos ensinamentos da dona Ofélia. Ela tem como objetivo de vida se casar com algum bom partido da cidade e essa busca fez com que a caçula fugisse com Uirapuru, o poeta, o que resultou na gravidez da moça. Nos capítulos 109 e 110, Felisberto descobre que Lídia está grávida e afirma que um neto é bem-vindo, no entanto eles sabem como a sociedade trata as mães que não são casadas. Lídia afirma que ela e o Uirapuru vão se casar e Mariana reitera que isso não acontecerá, pois ele não será responsável ao ponto de casar-se com ela. Ofélia afirma que Lídia será mãe solteira e que dificilmente irá se casar, mas Felisberto diz que esse não é o único objetivo da vida das mulheres. No entanto, a busca por um marido para Lídia continua, mesmo ela grávida de outro homem.

Por último, Cecília, uma das filhas da família Benedito, foi a primeira a se casar e mudar para a casa da família do seu marido. O que mais intriga a moça é um mistério que ronda a Mansão do Parque, local em que ela vai morar. O desaparecimento de Josephine, mãe do seu esposo, sempre foi um mistério para ela e a história é que ela sumiu após passear de barco com o seu marido, o almirante Tiburcio. Cecília inicia a sua investigação sobre o desaparecimento da falecida sogra e, em um dia, o sogro da Cecília e responsável pelo desaparecimento da Josephine a convida para um passeio de barco para mostrar como a esposa caiu no lago. Em uma manobra, o almirante a joga no lago. Depois de nadar até a beira do lago, Cecília consegue se salvar e o sogro pede que ela nunca conte isso a ninguém, com medo da represália que ele poderia sofrer por parte dos filhos. No capítulo 84, exibido no dia 23 de junho de 2018, após uma discussão entre os membros da família Tiburcio, Cecília ameaça denunciar o almirante à polícia pela tentativa de homicídio que ele cometeu ao jogá-la no lago, da mesma forma que fez com a sua ex-esposa.

Apesar das mulheres terem mais destaque sobre o tensionamento sobre a sua posição da mulher, o que percebemos é que existe pouca busca por equidade entre os gêneros. Dessa forma, as mulheres se mostram as mais interessadas em buscar o seu empoderamento, enquanto os homens não tem participação efetiva dessa discussão. 


\subsection{AS MULHERES PRESENTES}

Gráfico 2 - Há mulheres em cena além da personagem?

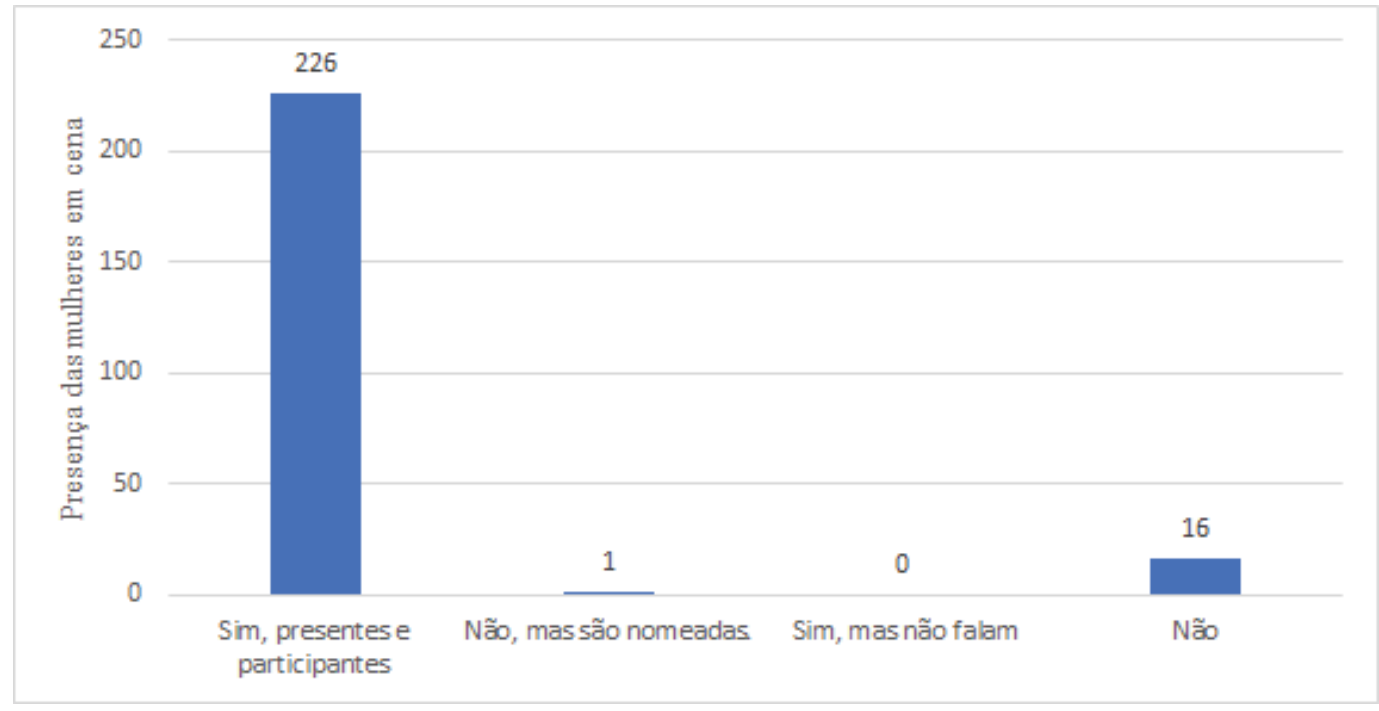

Fonte: Elaboração própria a partir dos dados analisados.

A intenção desse gráfico é verificar a participação das personagens femininas nas situações analisadas. A primeira coluna (sim, presentes e participantes) mostra que, em 226 das cenas analisadas, as mulheres estavam presentes e participavam da discussão. Nesse ponto, o que mais chama a atenção é a segunda coluna, que é quando os envolvidos falam sobre uma personagem feminina e não há nenhuma mulher presente naquele momento. Essa cena analisada pertence ao capítulo 45, exibido no dia 10 de maio de 2018, em que o Barão do Ouro Verde visita o Lorde Williamson, que comprou a sua fazenda após a falência da família Cavalcante ${ }^{30}$. Nesse momento, o Barão fala com o Lorde que tudo naquela casa é dele e o Lorde o corrige dizendo que os pertences da casa são dele, pois ele comprou da Julieta. O Lorde fala que o problema do Barão é com a Julieta e não com ele, e o Barão responde que Julieta não tem um diálogo civilizado e que os dois são velhos e ele irá compreender que ele não pode perder tudo que conquistou durante a vida toda. $\mathrm{O}$ Lorde afirma que a destruição de um patrimônio é resultado de anos de má gestão financeira e que ele é muito atento aos negócios dele. Nesse momento, podemos perceber que o Lorde reconhece a legitimidade da Julieta como uma mulher de negócios. Não identificamos momentos em que as

\footnotetext{
${ }^{30}$ Cavalcante é o sobrenome da família do Barão do Ouro Verde. Na trama, esse personagem é sempre tratado pelo título que ele recebeu.
} 
mulheres estão presentes e não participam da discussão. E, na última coluna, identificamos que há 16 ocorrências em que não temos mulheres presentes e que se configuram com momentos em que elas estão sozinhas ou são as únicas presentes na conversa.

\subsection{AS PROMESSAS DA NARRATIVA DE ORGULHO E PAIXÃO}

Gráfico 3 - Qual a promessa que a narrativa da cena propõe?

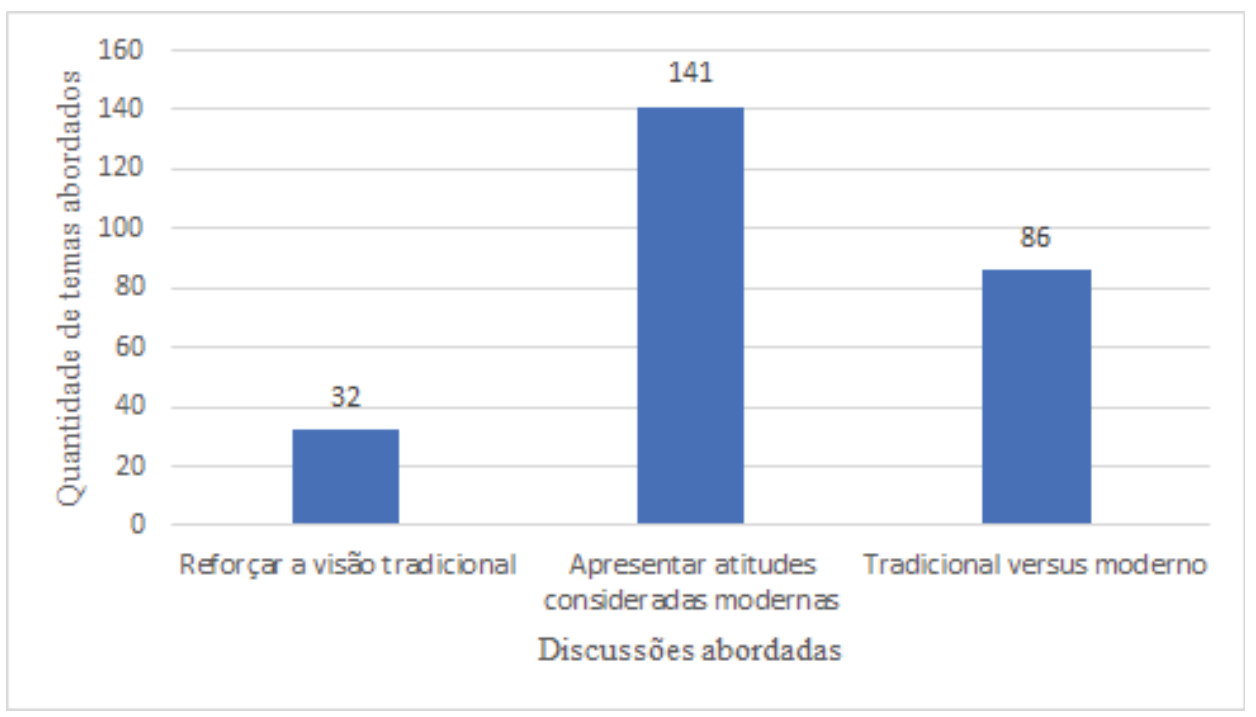

Fonte: Elaboração própria a partir dos dados analisados.

Identificamos que o tema mais apresentado nessa narrativa tem a ver com a apresentação de atitudes consideradas modernas. Optamos por trabalhar com essa denominação, pois compreende uma maior quantidade de ações que as personagens tomam que são opostas ao que se é esperado para as mulheres do século XX. Nesse caso, percebemos que o trabalho é a atividade mais recorrente quando falamos sobre essas atitudes modernas, e destacamos que as personagens Elisabeta, Ludmila, Julieta e Mariko são as que abordaram esse tema durante a narrativa televisiva. Outro ponto que podemos ressaltar é quando a Elisabeta afirma que ela quer conhecer o mundo e sair do Vale do Café, mas essa narrativa acaba se transformando na busca por um trabalho. A primeira oportunidade de emprego surgiu no capítulo 30, exibido no dia 23 de abril de 2018, quando Ludmila ofereceu à Elisabeta um cargo na fábrica da sua família. Posteriormente, Elisabeta conseguiu um emprego de colunista em um jornal da cidade, tornou-se repórter do seu próprio jornal e, depois, escritora de livros. 
A segunda personagem que se destaca é a Ludmila, que desde a sua aparição já mostra que é influenciada pela modernização, pois é presidente da empresa da família, dirige, veste calças e não tem o sonho de construir uma família. E as principais personagens que são afetadas pela por ela são Elisabeta, Ema e a Dona Ofélia. Elisabeta vê Ludmila como uma mulher inspiradora por ser uma trabalhadora; Ofélia e Ema a veem como uma das principais influenciadoras da Elisabeta para entrar no mundo do mercado de trabalho.

Julieta é a primeira personagem feminina que surge na trama como uma trabalhadora e mulher de sucesso no mundo profissional. As principais situações que ela se enquadra se trata de solucionar problemas relacionadas aos negócios do café. Em uma cena no capítulo 116, exibida no dia $1^{\circ}$ de agosto de 2018, Julieta afirma que precisa rever os planos dela com relação a plantação de café, que as terras estão quase para se esgotar, e Aurélio, seu par romântico, fala que eles vão encontrar uma solução e ele ficará ao lado dela. Essa passagem mostra a inversão dos papéis da sociedade, no caso em que a mulher trabalha e o homem é responsável por oferecer apoio à chefe da família. Outra cena que ilustra essa passagem é no capítulo 136, exibido no dia 24 de agosto de 2018, em que o Camilo (filho da Julieta) fala que precisa conversar com a Dona Julieta Bittencourt, a rainha do café, e não com a sua mãe. Julieta fala que eles deveriam ir para o escritório conversar. Essa cena mostra o reconhecimento da legitimidade da Julieta como uma pessoa de negócios, mas, ao mesmo tempo, promove uma separação entre ser mãe e trabalhadora.

Mariko é a outra personagem que representa as atitudes consideradas modernas com base no que era uma norma social para aquele século. No capítulo 83, exibido no dia 23 de junho e 2018, Mariko atende a Amélia, uma personagem que tem a saúde frágil e finge um desmaio depois de uma confusão em uma festa. Nessa cena, também estão presentes Rômulo, um outro médico, e Jorge, marido de Amélia. Mariko fala que irá examiná-la a sós, já que ela é médica, e Rômulo fala que também é médico e não faz sentido ele sair do quarto. Mesmo contra a vontade dos homens, eles saem do quarto e Mariko reforça a sua posição como profissional e mulher nesse momento.

No tópico de reforçar a visão tradicional, identificamos o casamento como o final da vida das mulheres. Dona Ofélia e Ema são as principais representantes dessa visão tradicional de que o casamento é o principal objetivo das mulheres. Temos como exemplo o capítulo 17, exibido no dia 7 de abril de 2018, em que Ofélia faz uma oração agradecendo a Jesus por salvar Ernesto e Darcy do acidente que eles sofreram na mina e aproveita para pedir que as suas cinco filhas se casem. No capítulo 32, exibido no dia 25 de abril, Darcy pede Elisabeta em casamento e ela rejeita o pedido 
por querer um outro destino para ela. Darcy afirma que não é sempre que alguém da classe social dele resolve pedir alguém da classe dela em casamento e Elisabeta afirma que essa mistura com outras posições sociais são um sacrifício para ele. No capítulo 33, exibido no dia 26 de abril de 2018, Ema afirma que o casamento de Elisabeta e Darcy seria lindo e que, ao sugerir que Darcy a pedisse em casamento, demonstrou que ela estava pensando no bem de Elisabeta. Esses são alguns exemplos que mostram que a temática do casamento está inserida na narrativa como um fim para as mulheres e como ultrapassa as gerações daquela sociedade.

$\mathrm{O}$ embate entre tradicional e moderno foi o segundo tema mais abordado dentro da telenovela e se configura como os embates entre as visões tradicionais e as atitudes consideradas modernas. Logo no primeiro capítulo, exibido no dia 20 de abril de 2018, já notamos que existe o conflito entre esses dois tipos de visões. Nessa situação, Ema fala com Elisabeta que ela tem que começar a pensar no seu futuro e se casar. Elisabeta afirma que quer encontrar um grande amor e se casar, mas essa não é a prioridade da sua vida, pois ela quer viver as suas experiências. No final do mesmo capítulo, Elisabeta aparece no baile oferecido por Ema vestida de calça e blazer, chocando quem estava presente. No capítulo 12, exibido no dia 2 de abril de 2018, Elisabeta encontra Ema que está no banheiro e reprime a amiga por tê-la incentivado a ir atrás de Jorge e revelar os seus sentimentos. Ema afirma que não deve fugir do seu destino que é cuidar do seu pai e avô. Elisabeta afirma que o lugar da Ema é onde ela quiser. No capítulo 28, exibido no dia 20 de abril de 2018, Ema incentiva Darcy a pedir Elisabeta em casamento, pois ela está encantada com o brilho da mulher moderna. No capítulo 35, exibido dia 28 de abril de 2018 , Ofélia afirma que criou as suas cincos filhas para se casar e que Elisabeta mudou por influência da Ludmila. Ludmila afirma que ninguém muda a outra e que Elisabeta é assim. Outro exemplo ocorre no capítulo 71, exibido no dia 9 de junho de 2018, quando Elisabeta comenta que quer entrevistar Ema para a sua coluna do jornal e Ema diz que ela não tem nenhum interesse para as pessoas, pois ela tem uma cabeça tradicional. Elisabeta afirma que Ema representa a maioria das mulheres que têm a família como prioridade.

Nesse tópico, identificamos que existem diferentes formas de empoderamento das mulheres no que tange o tema do trabalho. Para as mulheres como Mariko e Julieta, o ofício é uma necessidade de sobrevivência e para Elisabeta e Ludmila, o trabalho é um desejo de independência. E a outra forma de trabalho, que é o cuidado com do lar e das famílias está ligado a posição tradicional da mulher na sociedade. 


\subsection{ESSAS DISCUSSÕES SÃO DE CONFLITO OU CONCORDÂNCIA?}

\section{Gráfico 4 - A discussão é um conflito ou tem concordância?}

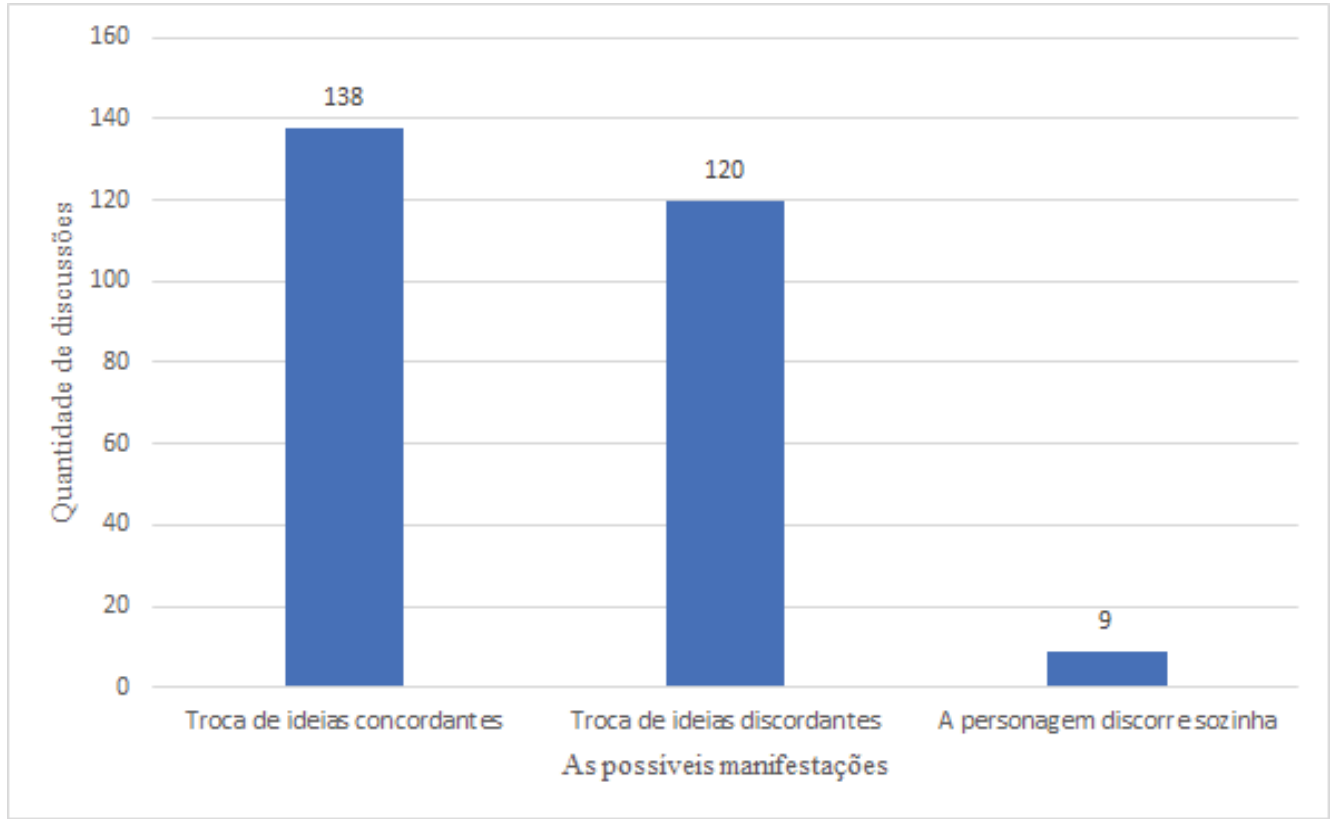

Fonte: Elaboração própria a partir dos dados analisados.

Nesse gráfico, buscamos verificar se as situações analisadas têm concordância ou discordância entre os personagens. E, durante o estudo, verificamos que existiam alguns momentos em que os personagens estavam sozinhos e isso levou à criação da opção em que eles discorriam sozinhos.

Identificamos que 138 discussões realizadas se tratavam de ideias concordantes. Destacamos que, nesse ponto, a maioria desses diálogos eram entre mulheres, mas eles também aconteciam com homens. Como exemplo, trouxemos a cena do capítulo 87, exibido no dia 28 de junho de 2018, em que Ema conversa com Edmundo, que se desculpa por ter estragado a festa de noivado dos dois. Ema se lembra de quando prometeu a seu pai que ela iria ser feliz e que por isso eles não deveriam se casar. Nesse caso, eles concordam que o casamento de conveniência não é a melhor escolha para os dois. Outro capítulo que destacamos é o 88, exibido no dia 29 de junho de 2018, em que Elisabeta se desculpa com o Venâncio por ele ter sido demitido do jornal em que os dois trabalhavam. Venâncio fala que Elisabeta não tem culpa por existir pessoas doentes e racistas na sociedade, como a Lady Margareth, e sugere que os dois criem o seu próprio jornal, desafio que 
ela aceita. O terceiro exemplo é no capítulo 97, exibido no dia 10 de julho, quando Elisabeta comenta da confraternização que eles farão para a inauguração do jornal dela e do Venâncio. Ludmila afirma que levará a imprensa para esse evento. Ema aproveita a conversa das três e conta que aceitará o emprego que Ludmila ofereceu a ela na loja de François. Ludmila fala que sempre soube que iria desvirtuá-la e levá-la para o lado das mulheres que trabalham. Um quarto momento de concordância que vemos na telenovela foi no capítulo 134, exibido no dia 22 de agosto de 2020, quando o Coronel Brandão apoia Mariana a denunciar a agressão e o sequestro que Xavier fez com ela. Ao chegar à delegacia, Mariana conta para o delegado que Xavier enviou os capangas para sequestrá-la e, depois, ele cortou os seus cabelos. Xavier surge na hora e acusa o Coronel de agredilo e tenta reverter a situação chamando-a de histérica.

As ideias discordantes são sobre momentos em que os personagens não chegam a um consenso quando eles abordam alguma situação em relação aos temas relacionados às mulheres, as quais foram identificadas em 120 das situações analisadas. Em primeiro momento, temos o capítulo 85, exibido no dia 26 de junho de 2018, quando Aurélio conversa com Ema e fala que ela não precisa se casar com Edmundo por causa do Barão e dele. Aurélio afirma que ele estava preso a convenções e se casar por obrigação é um erro. Ema afirma que gosta suficientemente de Edmundo para seguir com o acordo de casamento. Nesse caso, percebemos que havia a discordância entre o Aurélio e Ema e que a personagem feminina é a grande responsável por reforçar a visão tradicional da telenovela. No capítulo 87, exibido no dia 28 de junho de 2020, Elisabeta afirma que foi ofendida por Lady Margareth e que ela responderá com boa educação. Lady Margareth afirma que a educação brasileira não é a mesma da inglesa e que ela defenderá a sua família se Elisabeta os atacar e que Briana estava se guardando para o casamento com Darcy. No capítulo 114, exibido no dia 30 de julho de 2018, o Barão diz que o casamento de Ema e Ernesto é um erro. Ema responde que a partir de agora ela é a responsável por tomar as decisões da sua vida e que ela prefere passar a vida com a pessoa que ela ama do que perder essa oportunidade. Ela afirma que por muito tempo ficou presa às convenções sociais e que, agora, ela mudou.

Identificamos que em apenas nove de todas as situações analisadas as personagens estão sozinhas. A Elisabeta é a principal personagem que discorre sozinha nas cenas analisadas, apesar delas terem menores ocorrências. A primeira cena do capítulo um, exibido no dia 20 de maio de 2018, mostra Elisabeta segurando um globo terrestre quando afirma que ela vai conhecer o mundo inteiro ou pelo menos parte dele. A segunda cena destacada é no capítulo seis, exibido no dia 26 
de maio de 2018, quando Elisabeta leva Tornado, seu cavalo, para o topo de um morro onde é possível ver a ferrovia e ela afirma que aquilo é um sinal para ela sair do Vale do Café e que nenhum homem, inclusive o Darcy, irá impedi-la de realizar os seus sonhos. Os momentos sozinhos da Elisabeta também acontecem no último capítulo, o 162, exibido no dia 24 de setembro de 2018, quando mostra planos detalhes de porta-retratos da Elisabeta e do Darcy em diversos lugares do mundo e o som da voz dela afirmando que ela deu a volta no mundo que ela sempre sonhou. $\mathrm{E}$ outro momento é no mesmo capítulo, em que mostra imagens das personagens aproveitando a chuva de tinta. Elisabeta fala que, no Vale do Café,

[...] existem homens e mulheres de antigamente e com hábitos imutáveis e retrógrados e que pensam em receber as coisas como as receberam dos seus pais. E que acham que homens saem de casa para trabalhar e que as mulheres ficam em casa para sorrir e cuidar dos filhos. Mas lá também tem homens maravilhosos que encaram os amores, filhas, irmãs, primas, mães e esposas como seres iguais e recebem de volta pessoas plenas, satisfeitas e realizadas. E temos também mulheres especiais como em nenhum outro lugar. Temos mães, donas de casa, jornalistas, modistas, lavadeiras, médicas e até rainha, a rainha do café. Temos mulheres que mais do que serem aquilo que nasceram para ser vão fazer são o que querem ser. É isso, no Vale do Café, tem pessoas que querem inventar o que elas querem ser para si e vão atrás dos desejos. E isso é bom demais (ORGULHO E PAIXÃO, 2018) $)^{31}$.

Nessas cenas em que a personagem está sozinha ela mostra quais são as suas reflexões sobre o que ela deseja fazer. Percebemos que essa trajetória da personagem que queria sair do Vale do Café e conhecer o mundo aconteceu, mas com o seu marido. Essa última cena apresentada foi o fechamento da telenovela e mostra claramente essa diferença entre os homens e mulheres daquela sociedade e que essas figuras femininas buscam um destino diferente daquele que é dado naquela sociedade.

\subsection{OS PAPÉIS MAIS RECORRENTES DAS MULHERES EM ORGULHO E PAIXÃO}

A partir da leitura que fizemos da bibliografia que conta a história das mulheres, identificamos que existiam quatro posições que as mulheres poderiam ocupar dentro da sociedade do século XX, que são as de mãe, irmã, esposa e trabalhadora. Dessa forma, buscamos verificar

\footnotetext{
${ }^{31}$ Transcrição de uma fala da novela.
} 
quantas vezes essas posições estavam presentes dentro da narrativa de Orgulho e Paixão. Com o decorrer da coleta de dados, percebemos que as mulheres podem ocupar outras posições e, por isso, decidimos incluir a opção para contemplar essas outras opções.

\section{Gráfico 5 - Quais papéis são identificados para as mulheres?}

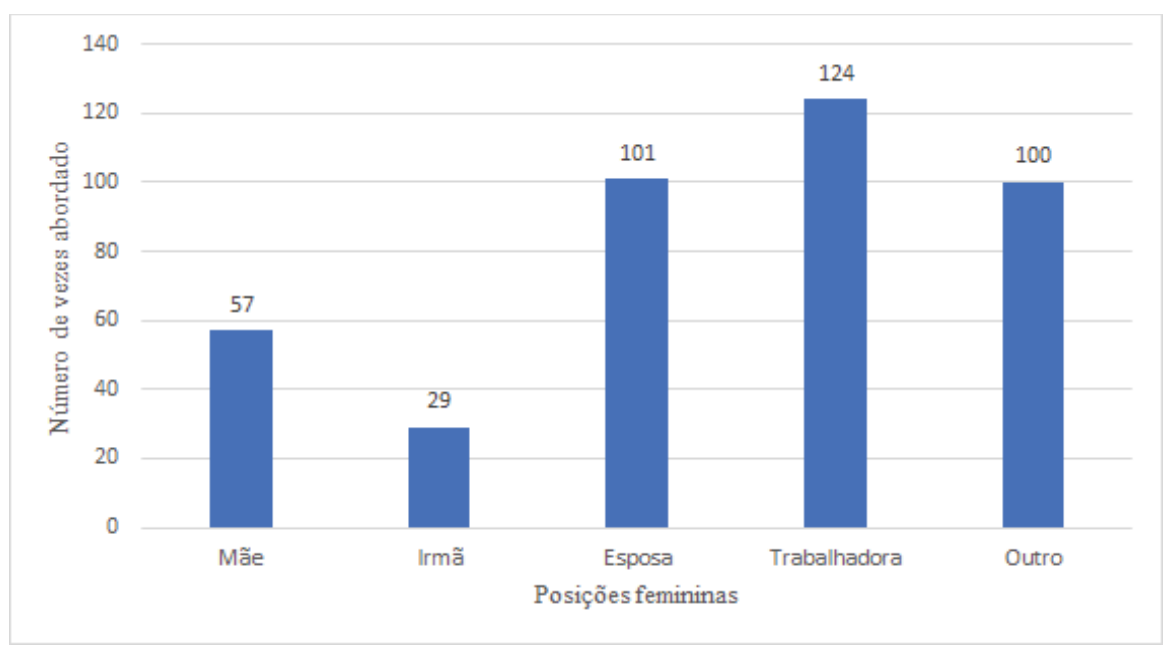

Fonte: Elaboração própria a partir dos dados analisados.

Como percebemos, ao longo da narrativa, a mulher trabalhadora foi o papel mais identificado para as personagens de Orgulho e Paixão. Nesse caso, vimos que as principais representantes da posição são Elisabeta, Julieta, Ludmila e Mariko. Identificamos que Elisabeta é que passa por esse processo de descobrimento sobre o trabalho e que mostra estar interessada em ingressar nesse mundo. As outras personagens já estão inseridas nesse universo e servem de inspiração para que a Elisabeta se insira no mercado de trabalho. Por outro, tem personagens como a Ofélia e Ema, que percebem isso como uma forma de atrapalhar o casamento das mulheres.

A posição de esposa é a segunda que mais aparece nas narrativas utilizadas e identificamos isso: o casamento é um dos temas mais presentes nessa narrativa. Também notamos que as principais personagens que representam o matrimônio são Ema e Ofélia. Elisabeta também é uma personagem que flerta com o casamento, pois durante toda a narrativa ela tem um relacionamento amoroso e é pedida em casamento por Darcy, no capítulo 32, exibido no dia 25 de abril de 2018, porém ela não aceita porque ele não pergunta a ela quais são os seus planos para o futuro. Nesse caso, percebemos que, para Darcy, o matrimônio é algo muito importante para a união do casal, mas Elisabeta não divide da mesma opinião, pois ela rejeita o seu pedido. Dessa forma, o casal 
principal só sela a sua união quando Elisabeta decide se casar e pede a mão de Darcy em casamento no capítulo 74, exibido no dia 13 de junho de 2018.

A posição aparece em terceiro lugar nesse gráfico, pois ele contempla outra classificação que não identificamos no referencial teórico, que é o de amiga. Além disso, esse caso também contempla diversos momentos na narrativa que a classificação "mulher" serviria para descrever a posição na qual aquela personagem estava sendo colocada. No entanto, buscamos analisar para tentar entender quem eram essas mulheres. Percebemos que essa posição se transparece quando as personagens dão apoio para outras que não fazem parte do seu ciclo familiar, mostrando a sororidade existente entre elas. As relações mais marcantes são entre Ema e Elisabeta, que dividem essa relação entre momentos de apoio e discussões discordantes sobre o casamento e o destino da mulher. Outra relação importante é quando Elisabeta e Ludmila incentivam Ema a aceitar o seu primeiro emprego na loja de roupas de François para conseguir pagar as suas contas do cortiço. Elisabeta também mostra ter uma relação de amizade forte com a Julieta, a rainha do café, que é construída ao longo da telenovela e se mostra muito forte quando Julieta decide contar a Elisabeta que ela sofreu um estupro do seu marido falecido, no capítulo 81, exibido no dia 21 de junho de 2018.

Com relação à mulher como mãe, percebemos esse discurso mais presente quando Ofélia falava sobre a sua obrigação de fazer com que as cinco filhas se casassem e, também, na relação de Camilo e Julieta. Para Ofélia, era seu dever como mãe garantir que suas filhas fizessem bons casamentos para não terem que depender do dinheiro da família Benedito. Julieta tem uma relação conturbada com Camilo, pois, como ele foi fruto de um estupro, ele se materializava como a representação da violência que ela sofreu no seu casamento. Outra personagem que se vê diante da posição materna é Lídia, a filha caçula da família Benedito, que engravida antes de se casar e se torna uma preocupação para Ofélia, pois a matriarca afirma que ninguém irá se casar com uma mãe solo. Outra personagem que tem um embate com a questão de ser mãe é Ludmila, que, no capítulo 157, exibido dia 18 de setembro de 2018, discute com Januário sobre a maternidade. Para Januário, a maternidade é algo que pode inspirar as mulheres naquele momento e, para Ludimila, as mulheres podem alcançar a felicidade de outra forma, como sendo inteligentes, sagazes e bonitas. Para Januário, ser mãe não impede que ela tenha outras qualidades, mas Ludmila afirma que isso é o mesmo que seguir o figurino. 
Em relação à classificação das irmãs, percebemos que ela se faz presente quando as irmãs Benedito estão se relacionando por meio de alguma interação. Como elas são as únicas jovens que têm esse grau de parentesco, ele acaba ocorrendo com menos frequência nas situações analisadas, pois, nas cenas observadas, haviam poucos diálogos entre elas. Isso não mostra que elas tinham pouca participação dentro da narrativa, mas que elas se relacionam com outras que não eram suas irmãs.

\subsection{FORMATOS DE ABORDAGEM DA NARRATIVA}

\section{Gráfico 6 - Como essa temática foi abordada dentro da narrativa?}

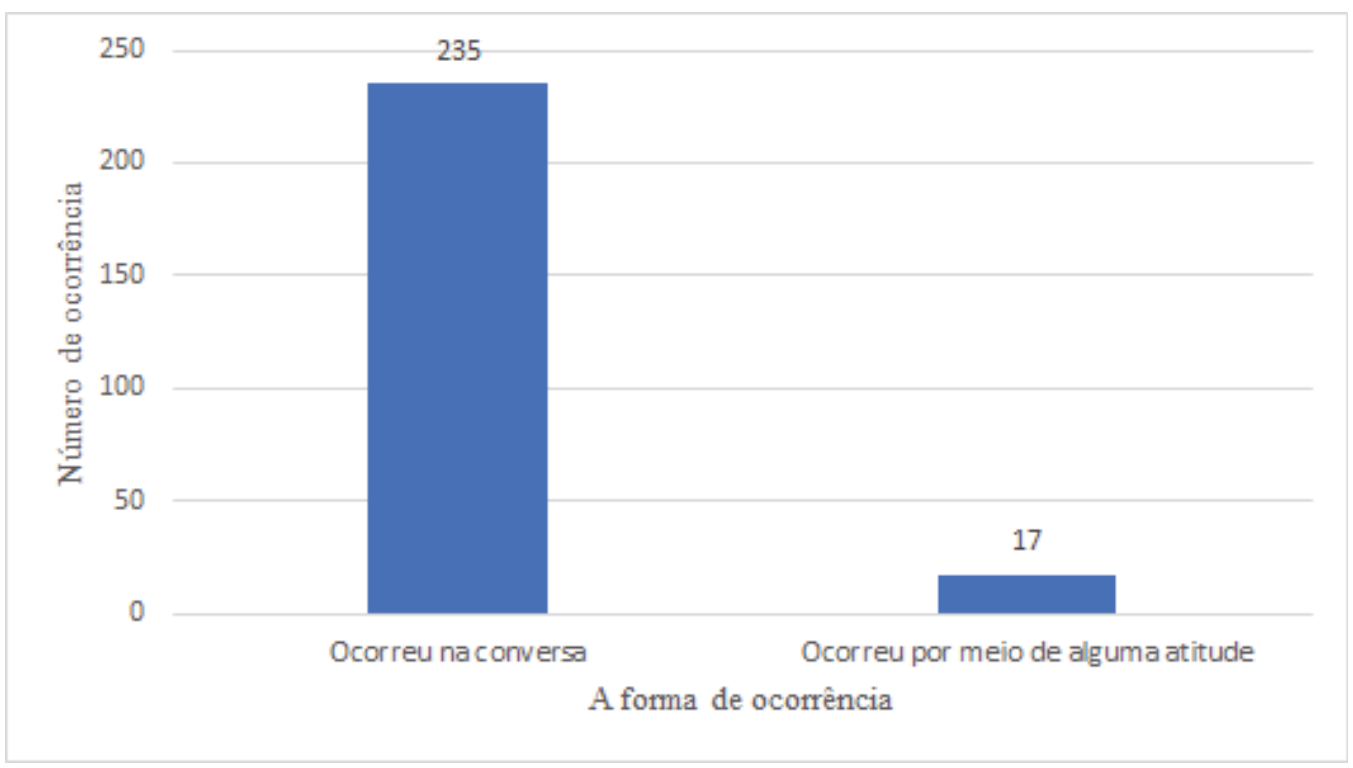

Fonte: Elaboração própria a partir dos dados analisados.

Em Orgulho e Paixão, percebemos que essas discussões poderiam se manifestar de duas formas, sendo elas por meio da fala ou de alguma atitude. Identificamos que a fala foi o meio mais utilizado pelas personagens para expressar as suas opiniões, em 235 casos. A tomada de alguma atitude e que fizesse com que as personagens ficassem surpresas com essa atitude aconteceu 17 vezes.

O que interessa saber nesse ponto é quais são as atitudes tomadas pelas personagens que poderiam trazer algum tipo de choque na comunidade ao seu redor por romper com as convenções sociais da época. A primeira atitude vem logo no final do primeiro capítulo da telenovela, quando 
Elisabeta e Darcy disputam a compra de uma calça para o baile. Como cada um puxa de um lado, a calça se rasga e, na hora de pedir desculpas, Darcy fala que a sua educação não indica que ele trate uma moça dessa forma. Elisabeta afirma que, só por ela ser mulher, ele está a tratando com pena e comiseração. Darcy a responsabiliza pela calça estar rasgada e ela afirma que, por ela ser mulher, ela vai costurar a calça. A segunda atitude ocorre no mesmo capítulo que é quando Elisabeta é a última a chegar no baile que Ema ofereceu. A personagem principal veste uma capa preta que só é tirada depois do seu nome ser anunciado. O jogo de câmera é muito importante nessa hora, pois ele mostra planos detalhes dos pés, da capa caindo no chão para manter o mistério da roupa que ela está vestindo. Ao revelar que Elisabeta está vestindo um terno no baile, Ofélia desmaia ao dizer que aquela é a sua filha. No segundo capítulo, exibido dia 21 de março de 2018, Ema puxa Elisabeta e pergunta que ideia maluca foi aquela e Elisabeta afirma que foi uma forma de se divertir e causar um rebuliço no baile.

No capítulo 23, exibido dia 14 de abril de 2018, Ludmila é a protagonista dessa atitude notável. Nessa cena, Ludmila encontra Elisabeta, Darcy e Ema conversando na casa do Jorge. Ludmila fala que dormiu lá, pois bebeu um pouco a mais na noite anterior e Jorge achou prudente que ela não voltasse dirigindo para casa. Ao se apresentar para Darcy, ele olha sua roupa e Ludmila fala que não adianta ele ficar olhando as suas calças, pois isso é apenas gosto para modas, e Darcy afirma que já está acostumado com a Elisabeta usando calças. Nesse mesmo capítulo, temos um outro momento que é quando Darcy pergunta à Ludmila o que ela faz além de usar calças à luz do dia e dirigir automóveis e Elisabeta afirma que isso é um questionamento muito indiscreto da parte do Darcy. Mas Ludmila não se espanta e fala que existem pessoas que fazem coisas piores e não falam ou não querem ver que isso está acontecendo.

No capítulo 58, exibido dia 25 de maio de 2018, Mariana vai à oficina de Luccino, seu amigo e mecânico do Vale do Café, e pergunta sobre as corridas clandestinas de motocicleta. O mecânico fala que é aquilo que ela viu e as mulheres não são bem-vindas por lá. Mariana afirma que adorou a sensação de liberdade e mostra que está usando calças para aprender a pilotar. No mesmo capítulo, Luccino a ensina a pilotar e fala que nunca viu nenhum homem aprender tão rápido. Mariana fala que vai competir, mas Luccino já adianta que as mulheres não fazem isso. $\mathrm{O}$ coronel Brandão chega à oficina e Mariana se esconde, pois ela está usando calças. Luccino pergunta ao coronel se alguma mulher já competiu e ele afirma que as mulheres são melhores que os homens em várias coisas, mas pilotar não é uma delas. Ao ouvir a explicação de Brandão, 
Mariana afirma que é um absurdo e aprenderá a pilotar por honra. Após esse ocorrido, Mariana começa a se vestir de Mário para competir de motocicleta. Depois, vestida de Mário, insere-se no mundo das corridas, ganha algumas delas, a confiança do Brandão e a desconfiança do Xavier, um fazendeiro rico do Vale do Café. Essa relação faz com que Xavier suspeite que há algo de errado com o Mário e inicia uma investigação sobre o rapaz. Ao descobrir que era Mariana vestida de homem, ele a sequestra e, no capítulo 127, exibido dia 14 de agosto, ele corta os cabelos dela como uma lição por tê-lo enganado. Mariana fica muito abatida com a perda dos cabelos, pois acredita que toda a sua feminilidade está presente nos seus cabelos e a sua perda a torna menos feminina; assim, ela passa a usar uma peruca com cabelos longos. No capítulo 148, exibido dia 7 de setembro, durante o seu casamento, ela se lembra do apoio do seu pai, Elisabeta e Luccino e ganha forças para tirar a peruca e mostrar os fios curtos. Todos os convidados ficam olhando e Ofélia desmaia dentro da igreja. No capítulo 149, exibido dia 8 de setembro, Mariana joga o bouquet para as moças do Vale e eles falam que a comemoração termina na casa deles e, para garantir que eles cheguem antes dos convidados, eles vão de motocicleta. Nesse momento, Mariana tira a saia, revela que ela está usando calças e os dois pegam as motocicletas.

\subsection{QUEM ESTÁ PRESENTE COM AS PERSONAGENS NO MOMENTO DAS DISCUSSÕES?}

\section{Gráfico 7 - Com quem as personagens estão interagindo no momento da reflexão do papel da mulher?}

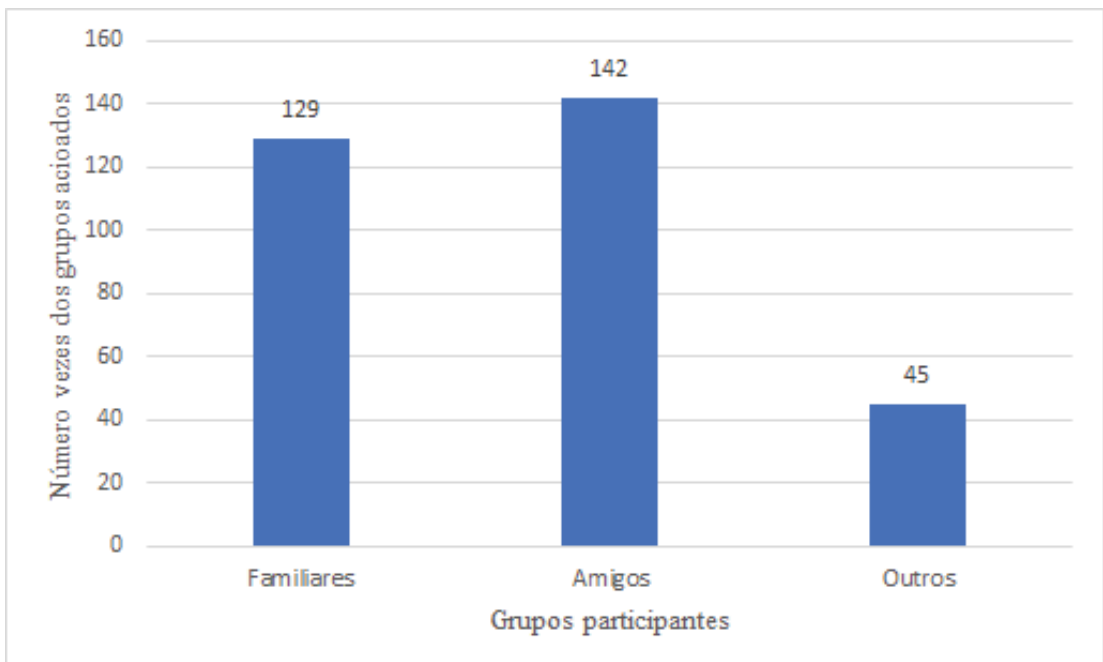

Fonte: Elaboração própria a partir dos dados analisados. 
As narrativas teleficcionais fazem uma representação da vida em sociedade e isso inclui as relações sociais no qual as pessoas estão inseridas, como a família e amigos. Os familiares são aqueles que possuem laços de sangue ou matrimoniais, já os amigos são aqueles que estão próximos, mas não têm relações de sangue ou matrimonial. Há também os demais personagens que fazem parte do dia a dia das personagens no Vale do Café ou em São Paulo, mas não têm tanta proximidade com os personagens que estão no foco da discussão com base na ficha de análise.

Em Orgulho e Paixão, identificamos que a maior parte das interações acontece com quem faz parte do seu círculo mais próximo: os amigos compõem 142 interações, os familiares 129 e outros 45 participações. A partir dessas reflexões, conseguimos perceber que são nas relações com as pessoas que estão mais próximas dentro do ciclo social que as personagens têm as maiores discussões sobre o papel das mulheres na sociedade do Vale do Café.

\subsection{AS NARRATIVAS INTERSECCIONAIS DENTRO DE ORGULHO E PAIXÃO}

Gráfico 8 - Existe interseccionalidade na narrativa?

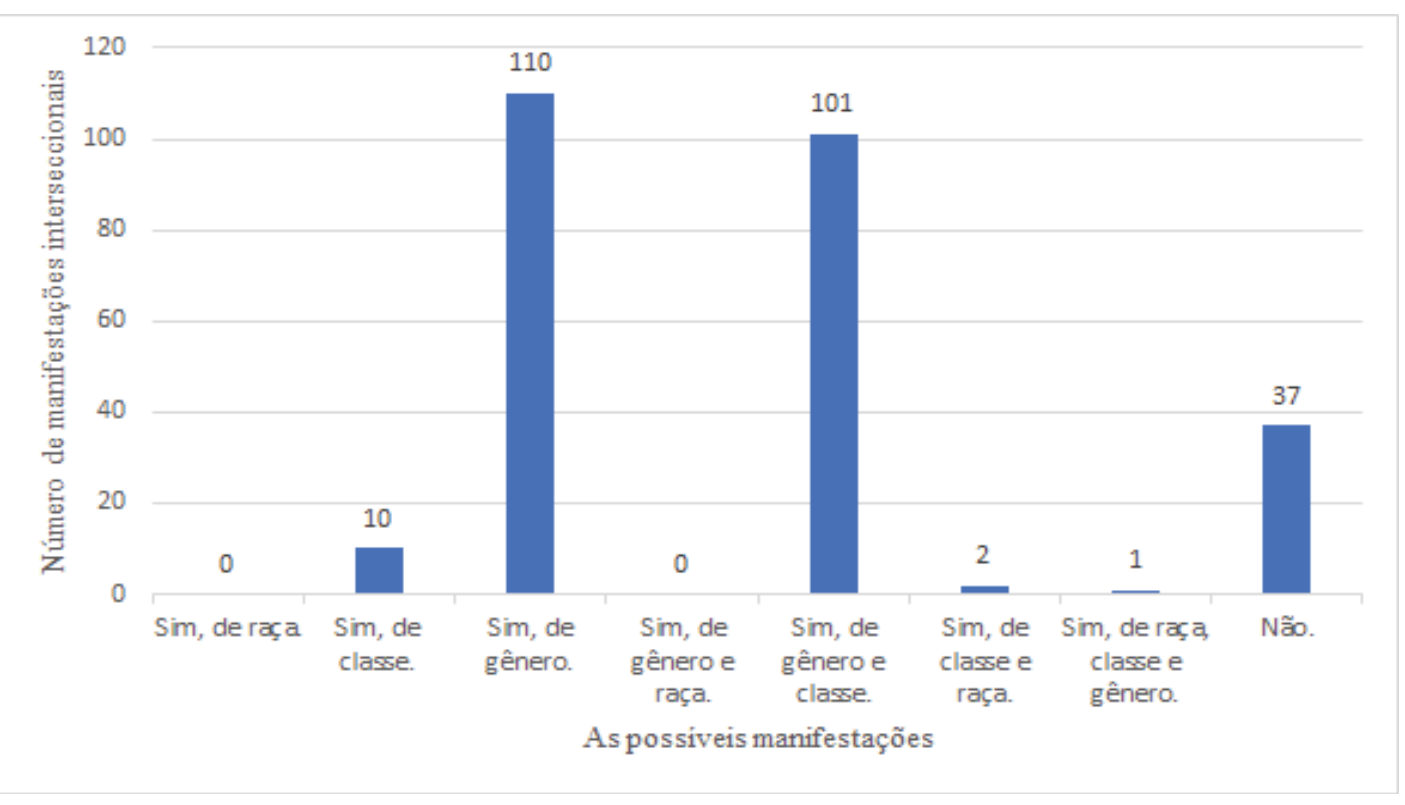

Fonte: Elaboração própria a partir dos dados analisados.

As narrativas interseccionais separadas para a análise dessa telenovela foram de raça, classe e gênero. Nesse sentido, conseguimos perceber que, dentro desses eixos de opressão, em 110 situações, elas se referiam a situação de gênero das mulheres. Com base nos dados, entendemos 
que elas sofreram algum tipo de repressão justamente por serem mulheres, e essas situações eram mais recorrentes quando as personagens buscavam de alguma forma romper com as convenções sociais da época. No capítulo 3, exibido dia 22 de março de 2018, Camilo, Darcy, Elisabeta, Jane e Suzana estão sentado à mesa e Camilo fala que se impressiona com a lista de talentos que uma moça pode ter, como cozinhar, bordar, costurar, tocar algum instrumento e desenhar. Darcy fala que não conhece moças que tenham tantas habilidades e Elisabeta afirma que ficaria surpresa se conhecesse alguma mulher que fizesse tudo isso, pois é uma exigência muito grande ter todos esses conhecimentos. Camilo fala que ela diz isso pois não conhece Julieta, que é tudo isso. Elisabeta afirma que quer conhecer uma mulher com tais habilidades e que ainda tem um negócio. No capítulo 4, exibido no dia 23 de março de 2018, Elisabeta e Darcy estão no carro discutindo e Darcy fala das atitudes de Elisabeta, que isso é histeria feminina, como Freud já havia diagnosticado. No capítulo 16, exibido dia 6 de abril de 2018, Elisabeta sugere que um grupo vá procurar outra entrada para a caverna. O responsável pela mina fala que a única coisa que faltava era uma mulher achar que sabe mais que o técnico. Elisabeta pergunta se o problema é ela ser mulher ou não ser técnica e diz que é preciso pensar em todas as possibilidades. O Coronel Brandão reconhece o conselho de Elisabeta e afirma que no dia seguinte eles iniciariam essa busca.

Em relação à interseccionalidade de gênero e classe, que apareceu 101 vezes nas nossas fichas de análise, entendemos que ela se manifesta quando estamos tratando de mulheres que trabalham. Optamos por essa classificação porque percebemos que a trabalhadora em Orgulho $e$ Paixão é uma posição que é vista durante toda a narrativa, e temos como principais representantes a Elisabeta, Julieta, Ludmila, Mariko e Ema. Além disso, colocamos na categoria de classe, pois o trabalho é a forma que elas possuem de prover o seu sustento financeiro e conquistar a sua independência. A liberdade e a independência são os principais desejos de Elisabeta, pois ela vê nisso a oportunidade que ela tem de romper com os laços sociais, e o trabalho é o meio encontrado para conquistar esses dois sonhos. Ludmila divide os mesmos anseios de Elisabeta e vê no trabalho uma forma de manter a sua independência pessoal e financeira. Para Julieta, Mariko e Ema, o trabalho é visto como uma forma de sustento pessoal e familiar. E é somente depois que Ema perde seu dinheiro que ela percebe como o trabalho também pode ser exercido pelas mulheres.

A interseccionalidade de classe aparece 10 vezes e esses momentos retratam quando a personagem em foco é colocada em uma situação em que a classe social é abordada na narrativa. No primeiro capítulo, Ofélia chama as filhas para uma conversa e fala com elas que todos os 
homens solteiros e de posses precisam de uma esposa. Elisabeta pergunta se são todos os homens ou somente os ricos. Ofélia afirma que os que têm posses precisam mais. No capítulo 32, exibido dia 25 de abril, Elisabeta é pedida em casamento por Darcy e ela não aceita, pois ele não a consultou antes sobre seus planos. Darcy afirma que não é sempre que alguém da classe dele pede alguém da classe dela em casamento e Elisabeta afirma que, para ele, isso é um sacrifício. No capítulo 40, exibido dia 4 de maio, Ludmila agradece por não ter se casado com Uirapuru e afirma que os homens têm medo da sua independência. No capítulo 42, exibido dia 7 de maio de 2018, Camilo e Ludmila falam que vão ajudar Ema, Elisabeta e Jane a pagarem um hotel em São Paulo para começar a vida. Elisabeta afirma que não precisa e que ficará no cortiço, que é o lugar que ela tem condição de pagar com o salário dela.

Quando falamos sobre a intersecção de classe e raça, temos apenas dois momentos nas nossas fichas de análise. No capítulo 52, exibido dia 18 de maio de 2018, Ema fala que Elisabeta está sendo rude ao falar sobre a situação da família. Ema acabou de descobrir que Tenória (uma mulher negra que trabalha na casa do Jorge) pode ser filha do seu avô e que isso pode causar mudanças na sua vida. Elisabeta pergunta se o motivo é porque Tenória é preta e pobre e Ema diz que não, pois eles sempre trataram bem os empregados, e Elisabeta fala que nenhum deles é da sua família. A segunda ocorrência é feita no mesmo capítulo e se trata da mesma questão. Ema fala que Elisabeta está sendo rude, que responde que isso é coisa do passado e nem existe mais herança para ser dividida.

A situação interseccional que aborda as três classificações, de raça, classe e gênero, aconteceu no último capítulo, o 162, exibido no dia 24 de setembro de 2018. Nesse momento, Elisabeta fala sobre as diversas mulheres que contribuíram para a formação do Vale do Café.

\subsection{O TENSIONAMENTO DAS CONVENÇÕES E O ENTENDIMENTO DAS PERSONAGENS}

No último gráfico, buscamos entender se os personagens que estavam presentes nas discussões conseguiram entender por meio da atitude ou da conversa o real objetivo de trazer um tensionamento as tradições. Em 164 das cenas analisadas os personagens entenderam o tensionamento com as tradições; em 100 situações, a resposta foi não; e em sete delas, a personagem estava sozinha. 


\section{Gráfico 9 - Há o entendimento com relação ao tensionamento da tradição?}

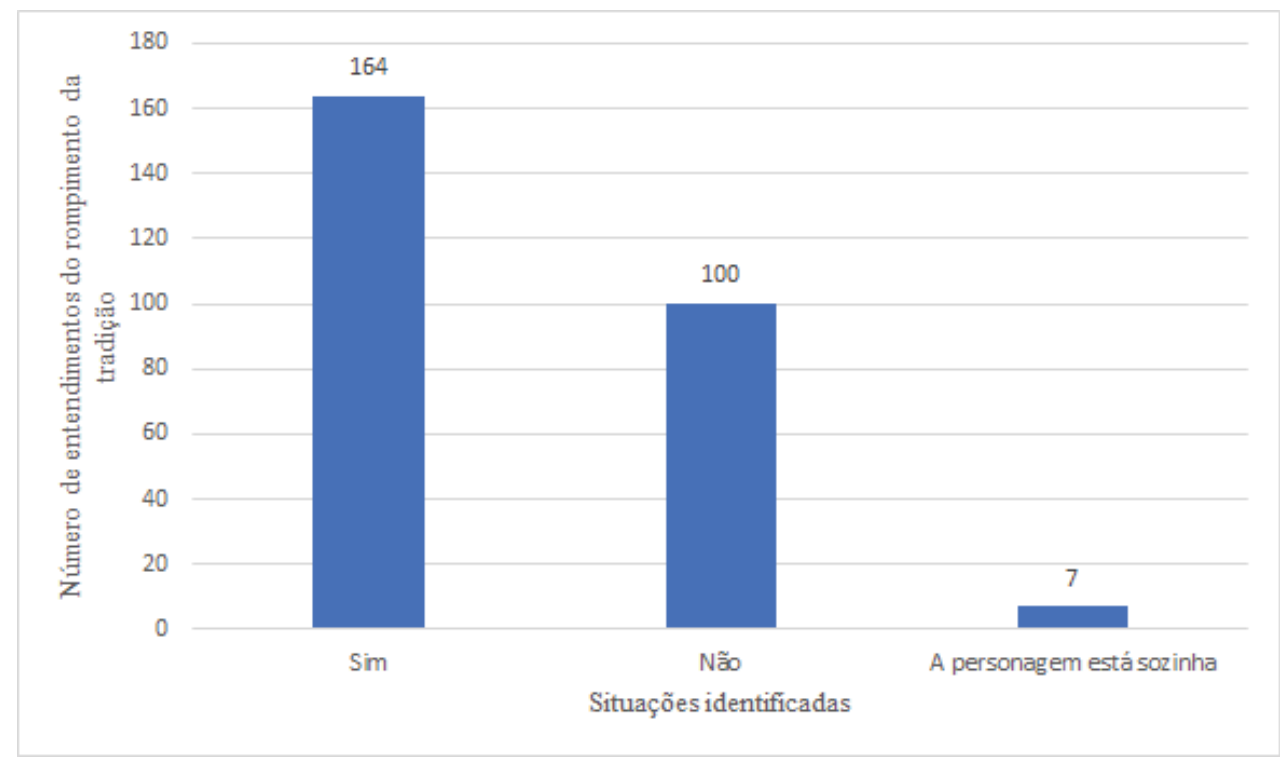

Fonte: Elaboração própria a partir dos dados analisados.

Com essa análise, percebemos que a maioria dos personagens conseguirem entender o tensionamento das tradições é um tema que foi trabalhado ao longo da telenovela. E as personagens que propunham essa discussão eram a Elisabeta e a Ludmila. Julita e Mariko, que também rompiam com as atitudes convencionais, faziam isso por meio das suas atitudes, especificamente a de trabalhar. Existem outros personagens que se destacam nesse momento, como Felisberto, pai das irmãs Benedito, Coronel Brandão, esposo da Mariana Benedito, e Aurélio, pai de Ema e marido de Julieta. No episódio 42, exibido dia 7 de maio de 2018, Elisabeta conta para os pais que quer se mudar para São Paulo. Ofélia fala que não perdoará Elisabeta se ela for. Felisberto afirma que Elisabeta está com uma escolha infeliz: se ela for para São Paulo, a Ofélia nunca mais falará com ela, e se não for, é ele quem não falará mais com ela. Felisberto reforça que Elisabeta tem o direito de ter os seus sonhos e que a mãe não pode diminuí-la por isso. No capítulo 110, exibido dia 25 de maio de 2018, Ofélia pede ajuda a Santa Rita de Cássia para interceder por Lídia, pois ela será mãe solteira, e Felisberto afirma que o casamento não é a única coisa na vida de uma mulher e que ela já deveria ter entendido isso. No caso do Coronel Brandão, no capítulo 16, exibido em 6 de abril, ele reconhece o conselho de Elisabeta para buscar uma outra saída para a mina que desabou. No capítulo 114, exibido no dia 30 de julho de 2018, o Coronel acompanha Mariana a corridas de motocicletas enquanto outros homens rejeitam a participação da moça: Brandão fala que Mariana 
conhece as regras da corrida e que os homens estão atrasados e na idade da pedra. Além disso, no capítulo 124, exibido em 10 de agosto, Brandão fala para eles fundarem uma liga em que homens e mulheres possam participar das corridas. No capítulo 85, exibido dia 26 de junho de 2018, Aurélio fala com Ema que ela não precisa se casar com um rapaz rico para ajudar a ele e ao Barão; ele afirma que se arrependeu de ter dado essa responsabilidade para ela. Nesse caso, Ema não aceita o conselho do pai e resolve seguir com o casamento de conveniência. Além disso, Aurélio reconhece as habilidades de Julieta como uma mulher de negócios e oferece seu apoio para as decisões que ela precisa tomar em seu império do café.

O não entendimento do tensionamento das tradições se caracteriza pelos momentos em que as personagens não concordam quando o tema da independência da mulher é colocado em pauta. Nesse momento, temos como principais expoentes a Dona Ofélia, Ema e Darcy. Para a primeira, o casamento é o principal objetivo da mulher e qualquer intervenção que as afastasse disso era errado. Ema, mesmo sendo amiga da Elisabeta, corrobora com os mesmos pensamentos, e como essas duas personagens estão muito próximas de Elisabeta, essa discussão se torna recorrente na narrativa. Darcy é o par romântico da Elisabeta e, como manda o figurino, ele a pede em casamento no capítulo 32, exibido dia 25 de abril de 2018. Elisabeta não aceita o casamento, pois afirma que ele não conversou com ela antes e não considerou os seus desejos.

A última opção foi escolhida para classificar os momentos em que as personagens em estudo estavam sozinhas e não era possível verificar se houve o tensionamento da tradição por meio da interação. Percebemos que são nesses momentos que elas fazem as suas principais reflexões, e a personagem em destaque para esse tópico é a Elisabeta. Os dois momentos mais marcantes da personagem foram no primeiro e no último capítulo. No primeiro, Elisabeta fala sobre a sua vontade de conhecer o mundo, e, no último, ela conclui falando sobre as diversas mulheres que fizeram parte da construção dessa cidade. No capítulo 6, exibido dia 26 de março de 2018, Elisabeta leva Tornado ao topo de um morro para mostrar-lhe a ferrovia e diz que aquilo é um sinal para ela sair dali, afirmando que nenhum homem irá impedi-la de atingir os seus sonhos. No capítulo 119, exibido no dia 4 de agosto de 2018, em off, Elisabeta narra a sua história de trajetória no Vale do Café e diz que ela precisa de força para ficar com Darcy e manter o trabalho e os seus sonhos vivos. No capítulo 125, exibido dia 11 de agosto de 2018, Elisabeta narra a história de que o Vale do Café foi construído por braços fortes de homens e de mulheres. A cena mostra imagens da família Benedito e muda a cena para Elisabeta escrevendo seu livro. 


\subsection{OS ENQUADRAMENTOS DE ORGULHO E PAIXÃO}

O enquadramento funciona como o olhar. Nielson Ribeiro Modro (2008) afirma que a câmera funciona como o olhar de quem filma e limita a forma como o telespectador verá o mundo. Na narrativa de Orgulho e Paixão, identificamos que o primeiro plano foi utilizado 163 vezes, o meio primeiro plano, 82 vezes, o plano médio, 121 vezes, o plano americano, 74 vezes, o plano geral, 59 vezes, o plano detalhe, 11 vezes, o plano fechado, três vezes e o plano conjunto cerca de duas vezes.

Percebemos que, como a maioria das cenas se tratam de diálogos, o jogo de câmera que ocorre e faz a troca entre o primeiro plano, o meio primeiro e o plano americano ocorriam com mais frequência na narrativa. Segundo Modro (2008), o primeiro plano é utilizado com o objetivo de focar o diálogo entre as personagens e para destacar algum detalhe daquela situação. Nesse caso, identificamos que os planos que deixam as personagens em destaque são os escolhidos para enquadrar esses momentos.

Figura 17 - Representação das casas do século XX

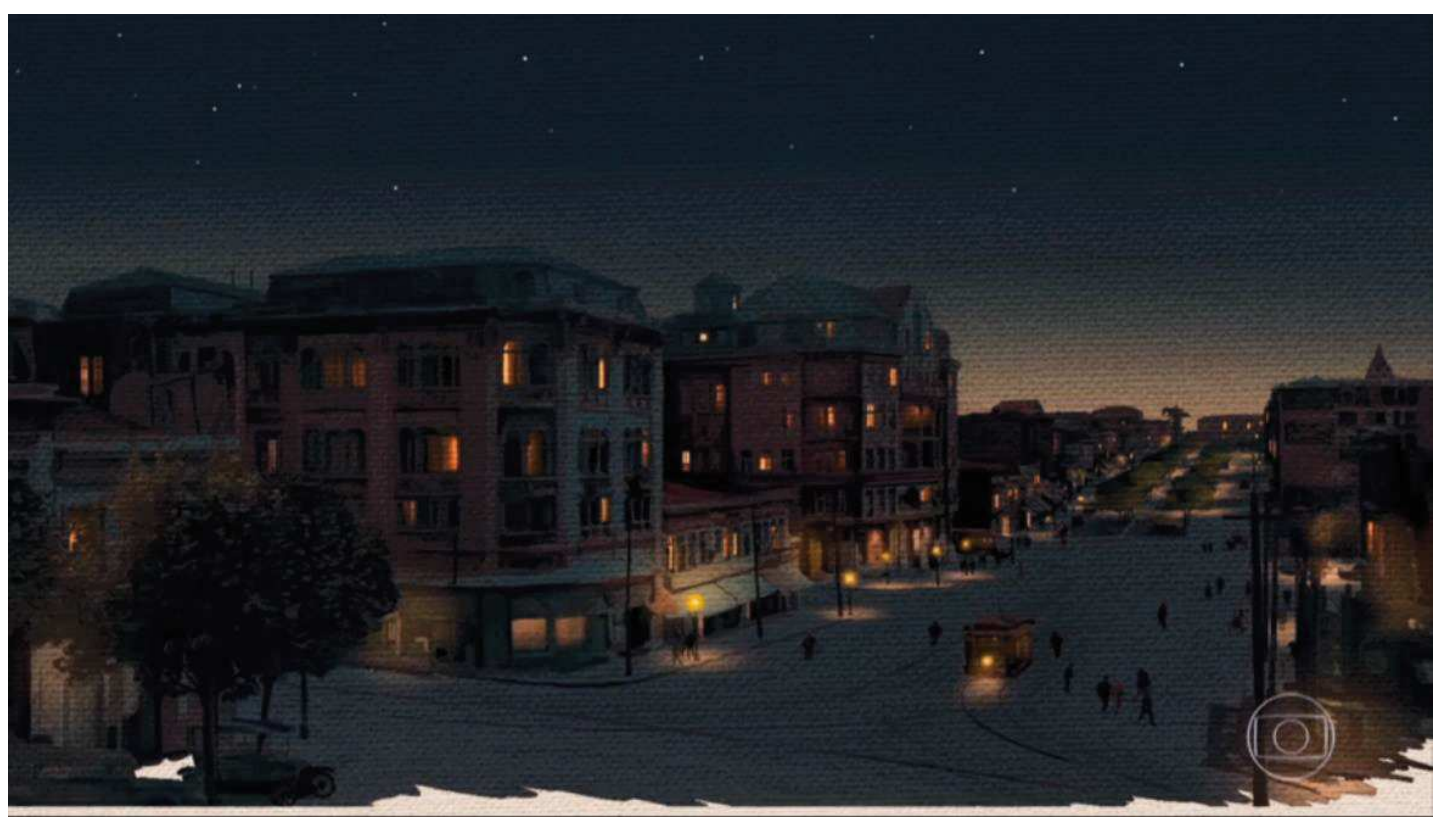

Fonte: print Globo Play (2018).

Os planos geral e médio são usados em sua maioria para as trocas de cenas e para ambientar os personagens nesse novo cenário. Após realizar esse processo ambientação em que o 
telespectador percebe essas mudanças, os enquadramentos voltam a se tornar o primeiro plano ou meio primeiro plano, utilizados para os diálogos. Um recurso usado pela telenovela para fazer essas passagens de cena são desenhos (Figura 17) que representam a cidade de São Paulo daquele século, já que não seria possível realizar a gravação e às vezes não foi necessário montar um cenário para essa representação. Os enquadramentos do plano geral das fachadas das casas do Vale do Café e em São Paulo, das lojas das cidades, do cortiço e do jornal que Elisabeta trabalha são usados como recurso para demarcar essas passagens de cena.

Os planos detalhe e fechado são recursos pouco encontrados nas cenas analisadas e contemplam situações em que algum objeto ou ação precisam ser mostrados em destaque. Temos como exemplo o capítulo 57, exibido dia 24 de maio de 2018, em que há um plano detalhe de Darcy desabotoando as roupas de Elisabeta. No capítulo 58, exibido dia 25 de maio de 2018, temos o plano detalhe quando o responsável pelo museu olha as minúcias da obra do Januário. No capítulo 66, exibido dia 4 de junho de 2018, vemos Elisabeta olhar com detalhe a sua primeira coluna sendo publicada no jornal.

\subsection{OS SONS PRESENTES EM ORGULHO E PAIXÃO}

Os sons na telenovela são usados como forma de ambientar as situações e lugares em que os personagens estão. O que notamos é que esse recurso é pouco explorado dentro da narrativa; o som ambiente, como falas e barulho de carros são recorrentes na narrativa, mas não ganham tanto destaque na análise. Dessa forma, identificamos como sendo algo usado para compor e dar a sensação de realidade para o telespectador.

Outro recurso usado pelas produções audiovisuais é a música para criar um clima na narrativa e para gerar sensações em quem está assistindo ao programa que vão contribuir para a imersão na narrativa. Percebemos a música em dois estados: o primeiro é o instrumental e o segundo com a voz dos próprios cantores. A música foi identificada 81 vezes nas cenas analisadas, sendo que em 59 delas o som era instrumental. Nas demais situações, percebemos que as músicas são acompanhadas das vozes dos cantores e se configuram como as músicas temas dos personagens. Esse recurso foi identificado em sua maior parte nos finais da cena e também serviam como forma de passagem de um enquadramento para outro. 
Percebe-se que esse recurso é usado para criar uma complementaridade na narrativa da telenovela. Os sons ambientes, como grilos à noite, carros, máquinas de escrever e talheres batendo nas louças são usados para dar a sensação de realidade naquela ação. Já as músicas são usadas para criar uma sensação a mais em quem está assistindo, podendo gerar o sentimento de angústia, medo, felicidade e tristeza. 


\section{CONSIDERAÇÕES FINAIS}

A partir das reflexões deste trabalho, percebemos que Orgulho e Paixão é um programa de televisão que apresenta duas temáticas centrais na sua narrativa, que são: o casamento e o trabalho. As atitudes das mulheres na sociedade são como o fio condutor que une esses dois assuntos e nos permitem fazer a análise desta pesquisa, que busca entender como a telenovela Orgulho e Paixão, por meio da personagem Elisabeta, promove o questionamento sobre os valores determinados para as mulheres no século XX e qual o paralelo pode ser feito com a sociedade contemporânea.

Identificamos a hipótese dessa pesquisa, que é: a telenovela constrói a imagem da Elisabeta como uma mulher à frente do seu tempo ao abordar os debates promovidos nos dias de hoje pelo movimento feminista, e Elisabeta se torna a personificação dessa busca. Para isso, ela deixa o lugar que era destinado às mulheres e luta para ter as mesmas condições dos homens. Identificamos que Elisabeta não é a única personagem que pode ser considerada como à frente do seu tempo e, além disso, para buscar o seu espaço de destaque na sociedade, as mulheres precisam entrar no mundo do trabalho.

A partir do desenvolvimento da pesquisa, percebemos que não é apenas Elisabeta que questiona os valores daquela época, existem outras personagens que promovem esse diálogo. Elisabeta é a personagem com mais destaque dentro da narrativa, mas percebemos que outras também ganharam destaque nas discussões e contribuíram para a construção dessa identidade feminina da telenovela, como Julieta, Ludmila, Mariana e Ema.

Verificamos que em quase todas as cenas havia pelo menos uma mulher presente na conversa. A única exceção é em uma conversa entre o Barão e o Lord Williamson, em que o primeiro não quer reconhecer que perdeu os seus pertences por causa da dívida que ele contraiu e o Lord afirma que o problema dele é com Julieta, pois foi ela quem pagou a sua dívida da família usando os seus pertences como forma de pagamento. O Barão afirma que Julieta não sabe dialogar como uma forma de deslegitimar a posição dela como uma mulher de negócios e que só o Lord, homem nobre, iria entendê-lo.

O trabalho é a atividade mais recorrente quando falamos das atitudes modernas, e destacamos que as personagens Elisabeta, Ludmila, Julieta e Mariko são as que abordaram esse tema durante a narrativa televisiva. Outro ponto que podemos destacar é quando Elisabeta afirma que ela quer conhecer o mundo e sair do Vale do Café, desejo que muda ao longo da narrativa e 
acaba se transformando na busca por um trabalho e uma independência financeira. A segunda personagem que se destaca é a Ludmila, que desde a sua aparição já mostra que é inserida na modernização, pois é presidente da empresa da família, dirige, veste calças e não tem o sonho de construir uma família. Julieta é a primeira personagem feminina que surge na trama como uma trabalhadora e como uma mulher de sucesso no mundo profissional. Ela já é estabelecida enquanto profissional e mulher de negócios, visto que, desde o seu aparecimento na narrativa, todos têm conhecimento da sua posição. Mariko também surge na telenovela como uma mulher formada e trabalhadora. As posições de Julieta e Mariko não são questionadas como a de Ludmila, que além de chefiar uma fábrica, fala abertamente sobre a independência feminina. Percebemos que o trabalho é percebido como um desejo por independência das mulheres e, também, uma necessidade de se sustentar. Para Pinto (2010), o feminismo surge como um movimento libertário, que além de buscar a conquista pelo espaço da mulher no trabalho, na educação e na esfera pública, anseia a reformulação no relacionamento entre homens e mulheres, no qual elas possam ter autonomia.

Quando se aborda o reforço da visão tradicional, identificamos o casamento como sendo considerado o final da vida das mulheres, e a Dona Ofélia e Ema são as principais representantes dessa visão tradicional. $\mathrm{O}$ embate entre tradicional e moderno foi o segundo tema mais abordado na telenovela e se configura como o conflito entre as visões tradicionais e as atitudes consideradas modernas. Percebemos que a principal discussão aqui é a questão do casamento e que as personagens com as visões mais tradicionais rejeitam a ideia da mulher moderna, que trabalha e se torna independente financeiramente. Dessa forma, D’Incao (2004, p. 192) afirma que:

[...] considerada base moral da sociedade, a mulher de elite, a esposa e mãe da família burguesa deveria adotar regras castas no encontro sexual com o marido, vigiar a castidade das filhas, constituir uma descendência saudável e cuidar do comportamento da prole.

Identificamos que 138 das discussões realizadas se tratavam de ideias concordantes. Destacamos que, nesse ponto, a maioria desses diálogos eram entre mulheres, mas eles também aconteciam entre homens. As ideias discordantes são sobre momentos em que os personagens não chegam a um consenso quando eles abordam alguma situação em relação aos temas relacionados às mulheres, e foram identificadas em 120 das situações analisadas. As discussões ocorrem em sua maioria com mulheres. Identificamos que em apenas nove de todas as situações analisadas as personagens estão sozinhas. 
As discussões poderiam se manifestar de duas formas, por meio da fala ou de alguma atitude. Identificamos que a fala foi o meio mais utilizado pelas personagens para expressar as suas opiniões, em 235 casos. A tomada de alguma atitude que fizesse com que as personagens ficassem surpresas aconteceu 17 vezes, e as atitudes tomadas pelas personagens poderiam trazer algum tipo de choque na comunidade ao seu redor por romper com as convenções sociais da época. Apesar de acontecer em poucos momentos, as atitudes tomadas pelas personagens ganham destaques e repercutem outros momentos da narrativa. Nesses casos, os momentos em que Elisabeta, Ludmila e Mariana optam por usar calças e mudar o visual do que seria o de uma mulher são notados pelas pessoas que estão ao seu redor como um espanto. Ludmila e Mariana ainda vão além e aprendem a dirigir e pilotar alguns meios de transportes. Mariana até opta por assumir uma identidade masculina para sentir o prazer de participar das corridas. Dessa forma, percebemos que essas atitudes são a materialização desses ideais modernos e quando se expressam por meio da fala, elas são consideradas apenas como sonhadoras ou influenciadas pelos ares da modernidade.

Identificamos que a maioria das relações e discussões acontecem com as pessoas que fazem parte do seu ciclo de amizade e, em segundo lugar, com os familiares. Isso nos mostra como as discussões e os embates sobre as questões sociais acontecem mais com quem está próximo das personagens pelo fato de a telenovela representar uma sociedade em que as pessoas que se relacionam têm um grau de proximidade. Isso reitera a posição de que as mulheres tinham mais voz no espaço privado, mesmo que existissem algumas que trabalhassem.

As narrativas interseccionais identificadas para a análise dessa telenovela foram as de raça, classe e gênero. Dentro desses eixos de opressão, nas 110 situações encontradas, o gênero era a principal categoria e identificamos que as personagens sofreram algum tipo de repressão justamente por serem mulheres; as situações eram mais usuais quando as personagens buscavam romper com as convenções sociais da época.

As categorias gênero e classe apareceram 101 vezes nas fichas de análise e entendemos a sua decorrência do fato de a figura da mulher trabalhadora estar presente em toda a narrativa. Elas trabalharem permite que tenham uma ascensão social na sociedade moderna por causa do salário que recebem. Apesar de o trabalho ser visto como uma necessidade de sustento para muitas delas, como Julieta, Mariko e Ema, Ludmila e Elisabeta percebem isso ainda como uma forma de emancipação e de liberdade da dependência dos seus familiares. 
A interseccionalidade de classe aparece 10 vezes e está ligada à questão da ascensão social da mulher pelo casamento. Os principais representantes desta caracterização são a Ofélia, Darcy e Ema. A primeira acredita que as filhas precisam se casar com homens ricos para não terem que depender do dinheiro da família Benedito. Já para Darcy, o fato de ele aceitar se casar com alguém de uma classe inferior a dele é vista como um sacrifício e um passo muito grande na sua vida. E, para Ema, o casamento é algo muito importante e, quando sua família fica falida, ela percebe que o casamento por conveniência com um rapaz de família rica pode ser a saída para resolver os seus problemas.

A interseccionalidade de classe e raça é muito pouco abordada dentro da telenovela e está presente em apenas dois momentos. Essa situação entra em debate quando Ema descobre que Tenória é filha do seu avô com uma escrava. Esse é um dos pontos da telenovela que poderia ser mais trabalhado. O contexto histórico da trama está próximo ao da abolição da escravidão e essa discussão é muito pouco abordada dentro das narrativas analisadas, apesar da discussão sobre raça estar presente em relação aos personagens Januário, o pintor, e Venâncio, o jornalista.

O momento interseccional que aborda as três classificações, de raça, classe e gênero, acontece no último capítulo e nas últimas cenas como uma reflexão feita por Elisabeta. Ao trazer esses três pontos, percebemos que a personagem usa essas intersecções para fazer um fechamento da conclusão que ela chegou sobre a história do Vale do Café. Para ela, é essa variedade de mulheres, com trabalhos, aspirações, sonhos e origens que contribuíram para construir a sua cidade. Como comenta Piscitelli (2008), conseguimos utilizar diferentes ferramentas para entender as múltiplas diferenças e desigualdades presentes nessa sociedade.

Em 164 das cenas analisadas, percebemos que os personagens entendem o tensionamento das tradições e esse é um tema que foi trabalhado ao longo da telenovela. Elisabeta e Ludmila eram as que propunham essa discussão pelo fato de exporem sempre as opiniões delas. E outras personagens, como Julita e Mariko, também rompiam com as atitudes convencionais, mas faziam isso por meio das suas atitudes, sobretudo trabalhando, mostrando uma outra forma de apresentar a sua independência. Nesse momento, percebemos que existem outros personagens que se destacam, como Felisberto, pai das irmãs Benedito, Coronel Brandão, esposo da Mariana Benedito, e Aurélio, pai de Ema e marido de Julieta. O fato de esses homens se mostrarem ao lado das mulheres e concordarem com as opiniões delas contribui para reforçar a validade das reivindicações delas. 
As personagens que não entendem esse tensionamento das tradições por parte das mulheres geralmente têm como discurso principal o tradicionalismo daquele período. E, nesse caso, os principais expoentes são Ema, Ofélia e Darcy. No entanto, Ema e Darcy mudam de posição no decorrer da telenovela.

Os enquadramentos mais encontrados foram o primeiro plano, o meio primeiro plano e o plano médio. Dessa forma, percebemos que o que mais se privilegiou nesses momentos foram os diálogos e as interações pelos personagens, e isso se confirma quando identificamos que as conversas são as interações mais comuns entre os personagens. Com relação aos sons utilizados na telenovela, o que mais se destaca são as músicas, tanto instrumentais quanto cantadas, que contribuem para criar sentimentos e sensações nos telespectadores.

Em relação ao paralelo que pode ser feito com a sociedade contemporânea, conseguimos perceber que as personagens que mais se destacam nessa narrativa têm atitudes que são consideradas corriqueiras nos dias de hoje. Vestir-se com calças, dirigir, trabalhar, ser dono ou gerente de um negócio são lugares que as mulheres já ocupam atualmente.

A principal reflexão é que, nesse século, essas atitudes e desejos das mulheres se tornam mais notáveis por destoarem do que se espera da vida delas. Percebemos que Elisabeta almeja a liberdade, que ela identifica como desejo de sair do Vale do Café e que aos poucos toma forma e se configura como a vontade de ter um emprego. E o ato de trabalhar, sustentar-se e ter independência financeira leva as personagens a entrarem em um mundo que é majoritariamente dominado por homens, tanto que Elisabeta se assusta quando vai à redação do jornal e não vê nenhuma mulher naquele local. Dessa forma, conseguimos perceber que elas precisam ir ao lugar e assumir essa posição deles para conquistar o que elas almejam. Isso mostra a busca das mulheres por uma equidade com os homens e ao buscarem ocupar os mesmos espaços.

Ao final, consideramos que Orgulho e Paixão aborda as questões do feminismo contemporâneo na sua narrativa, como a violência contra a mulher em pelo menos duas cenas, e que as principais representantes desse posicionamento são Elisabeta, Ludmila e Ema. Apesar da personagem principal ser a que mais tem participação na inserção desse assunto, os outros personagens contribuem no sentido de deixar mais evidente essa discussão por meio da concordância ou da discordância. Há outras personagens que também contribuem para mostrar essa posição da mulher moderna, que é vista como sendo influência da modernidade que chegava ao interior de São Paulo e ameaçava os antigos costumes. Percebemos que a busca pelo trabalho pode 
ser identificada como um desejo de realização pessoal das mulheres de serem independentes e como forma de se sustentar. O trabalho doméstico, que consiste no cuidado da família, do lar e da casa, não é percebido como um trabalho, mas sim como um dever das mulheres, como esposas. Isso resulta no tensionamento dos valores tradicionais, que é identificado por muitos personagens como algo incômodo. E essa busca pela independência e pelo trabalho consiste na procura pela equidade entre homens e mulheres.

$\mathrm{O}$ fato de ser uma produção que representa o início do século XX também ajuda na identificação dessas personagens, pois, como a sociedade daquela época tinha o discurso tradicional mais presente, o trabalho como forma de libertação e desejo, o uso de calças, dirigir ou pilotar uma moto, fazer uma graduação e ter um negócio próprio eram vistos como diferentes nesse contexto. 


\section{REFERÊNCIAS BIBLIOGRÁFICAS}

ALENCAR, Mauro. A Hollywood brasileira: panorama da telenovela no Brasil. Rio de Janeiro: Senac, 2002.

ALMEIDA, Heloisa Buarque de. Telenovela, consumo e gênero "muitas mais coisas". Bauru: Edusc, 2002.

BERGER, Peter; LUCKMANN, Thomas. A construção social da realidade - tratado de sociologia do conhecimento. 24. ed. Rio de Janeiro: Vozes, 2004.

BRANDÃO, Cristina; FERNANDES, Guilherme Moreira. Telenovela brasileira - formato que vem se impondo há seis décadas. In: BRANDÃO, Cristina; COUTINHO, Iluska; LEAL, Paulo Roberto Figueira (Orgs.). Televisão, Cinema e Mídias Digitais. 1. ed. Florianópolis: Insular, 2012, v. 1, p. 183-204.

BOURDIEU, Pierre. O poder simbólico. 10. ed. Rio de Janeiro: Bertand Brasil, 2007.

BUTLER, Judith. Problemas de gênero: feminismo e subversão da identidade. Rio de Janeiro: Civilização Brasileira, 2018.

CISNE, Mirla. Feminismo e consciência de classe no Brasil [livro eletrônico]. São Paulo: Cortez, 2015.

COUTINHO, Iluska Maria da Silva. Compreender a estrutura do audiovisual e experimentar o audiovisual - Da dramaturgia do jornalismo à análise da materialidade. In: EMERIM, Cárlida; COUTINHO, Iluska; FINGER, Cristiane (Orgs.). Epistemologias do Telejornalismo Brasileiro. 1.ed. Florianópolis: Insular, 2018. v. 7.

DELPHY, Christine. Patriarcado (teorias do). In: HIRATA, Helena; LABOR IE, Françoise; DOARÉ, Hélène Le; SENOTIER, Danièle (Orgs). Dicionário Crítico Do Feminismo. São Paulo: Unesp, 2009.

D’INCAO, Maria Ângela. Mulher e família burguesa. In: PRIORE, Mary Del. História das Mulheres no Brasil. São Paulo: Contexto, 2004. Disponível em: https://democraciadireitoegenero.files.wordpress.com/2016/07/del-priore-histc3b3ria-dasmulheres-no-brasil.pdf. Acesso em: 18 jan. 2020.

GARCIA, Ana Luíza Rezende. Um Novo Brasil, Uma Nova Novela: a reformulação da Rede Globo para atender a nova classe C. 2013. 58 f. Trabalho de Conclusão de Curso (Bacharelado) Universidade Federal de Juiz de Fora. Juiz de Fora: UFJF, 2013.

HAMBURGUER, Esther. Diluindo Fronteiras: As Telenovelas no Cotidiano. In: SCHWARCZ, Lilia (Org.). História da Vida Privada. São Paulo: Companhia das Letras, 1998. 
HAMBURGER, Esther. Telenovelas e Interpretações do Brasil. In: Lua Nova. Revista de Cultura e Política, v. 82, p. 61-86, 2011.

KELLNER, Douglas. A Cultura da Mídia - Estudos culturais: identidade e política entre o moderno e o pós-moderno. Bauru: Edusc, 2001.

KEHL, Maria Rita. A constituição da feminilidade no século XIX. In: KEHL, Maria Rita. Deslocamentos do feminismo. São Paulo: Boitempo, 2016.

LEAL, Ondina Fachel. A leitura social da novela das oito. Petrópolis: Vozes, 1986.

LOPES, Maria Immacolata Vassalo de. A telenovela como narrativa de nação: Para uma experiência metodológica em comunidade virtual. In: Signo y Pensamiento, Bogotá, v. XXIX, n. 51, p. 130-141, 2010.

LOPES, Maria Immacolata Vassalo de. A telenovela como narrativa da nação: notas para uma experiência metodológica em comunidade virtual. In: XVII Encontro da Compós UNIP, São Paulo, 2008. Disponível em: http://www.compos.org.br/data/biblioteca 351.pdf. Acesso em: 11 jul. 2020.

MALUF, Marina; MOTT, Maria Lúcia. Recônditos no mundo feminino. In: SEVCENKO, Nicolau (Org.). História da Vida Privada no Brasil 3. São Paulo: Companhia das Letras, 1998.

MARTÍN-BARBERO, Jésus. Dos meios às mediações: comunicação, cultura e hegemonia. Rio de Janeiro: UFRJ, 1997.

MARTÍN-BARBERO, Jésus; REY, Germán. Os exercícios do ver: hegemonia do audiovisual e ficção televisiva. São Paulo: Senac, 2001.

MODRO, Nielson Ribeiro. Nas entrelinhas do cinema. Joinville: Univille, 2008.

ORTIZ, Renato. A moderna tradição brasileira: cultura brasileira e indústria cultural. 4. Reimpr. 5. ed. São Paulo: Brasiliense, 2001.

ORTIZ, Renato; BORELLI, Silvia Helena Simões; RAMOS, José Mário Ortiz. Telenovela: história e produção. São Paulo: Brasiliense, 1989.

PERROT, Michelle. Minha história das mulheres. São Paulo: Contexto, 2007.

PINTO, Céli Regina Jardim. Uma história do feminismo no Brasil. São Paulo: Fundação Perseu Abramo, 2003.

PINTO, Céli Regina Jardim. Feminismo, História e Poder. In: Rev. Sociol. Polít., Curitiba, v. 18, n. 36 , p. 15-23, jun. 2010.

PISCITELLI, Adriana. Interseccionalidade, categorias de articulação e experiências de migrantes brasileiras. In: Sociedade e Cultura, n. 2, v. 11, p. 263-274, jul./dez., 2008 
PONTES, Denyse, DAMASCENO, Patrícia. As Políticas Públicas Para Mulheres no Brasil: Avanços, conquistas e desafios contemporâneos. In: Seminário Internacional Fazendo Gênero 11 \& 13th Women's Worlds Congress (Anais Eletrônicos), Florianópolis, 2017.

RIBEIRO, Djamila. O que é: lugar de fala?. Belo Horizonte (MG): Letramento, 2017

SCHWARCZ, Lilia. Sobre o autoritarismo. São Paulo: Companhia das Letra, 2019.

SCHWARCZ, Lília Moritz. População e sociedade. In: SCHWARCZ, Lilia Moritz (Org.). A Abertura para o Mundo 1889-1930. 1. ed. Rio de Janeiro: Objetiva, 2012.

SOIHET, Raquel. Mulheres pobres e violência no Brasil urbano. In: PRIORE, M. D. História das Mulheres no Brasil. São Paulo: Contexto, 2004. Disponível em:

https://democraciadireitoegenero.files.wordpress.com/2016/07/del-priore-histc3b3ria-dasmulheres-no-brasil.pdf $>$. Acesso em: 18 jan. 2020.

SODRÉ, Muniz. O Monopólio da Fala: função e linguagem da televisão no Brasil. Petrópolis: Vozes, 1984.

TÁVOLA, Artur da. A telenovela brasileira: história, análise e conteúdo. São Paulo: Globo, 1996.

TORISU LEMOS, Bárbara. O Espaço Destinado Às Mulheres Na Telenovela Orgulho e Paixão. In: $\mathbf{4 2}^{\circ}$ Congresso Brasileiro de Ciências da Comunicação, UFPA - Belém, 2019. Disponível em: https://portalintercom.org.br/anais/nacional2019/resumos/R14-0803-1.pdf. Acesso em: 13 out. 2020.

TORISU LEMOS, Bárbara. Telenovelas, estudos de gênero e direitos da mulher: uma análise sobre os artigos publicados no Intercom Nacional de 2014 a 2019. In: COUTINHO, Iluska; PEREIRA, Gustavo (Orgs.). Vídeo Sapiens: Jornalismo, Audiovisual e Direitos Humanos. Florianópolis: Insular; UFJF, 2020. Disponível em: https://www.ufjf.br/ppgcom/files/2020/03/Livro-NJA-2020V\%c3\%addeo-Sapiens.pdf. Acesso em: 13 mar. 2021. 


\section{ANEXOS}

ANEXO A - Tabela de telenovelas

A tabela referente ao Anexo A está disponível neste link 
Ficha catalográfica elaborada através do programa de geração automática da Biblioteca Universitária da UFJF, com os dados fornecidos pelo(a) autor(a)

Torisu Lemos, Bárbara.

A REPRESENTAÇÃO DE GÊNERO NA TELENOVELA : um estudo sobre Elisabeta e as personagens femininas em Orgulho e Paixão. /Bárbara Torisu Lemos. -- $2 \mathrm{O} 21$.

$143 p$.

Orientadora: Iluska Maria da Silva Coutinho

Dissertação (mestrado acadêmico) - Universidade Federal de Juiz de Fora, Faculdade de Comunicação Social. Programa de Pós-Graduação em Comunicação, $2 \mathrm{O} 21$.

1. Comunicação. 2. Telenovela. 3. Análise da Materialidade Audiovisual. 4. Orgulho e Paixão. 5. Estudo de gênero. I. Maria da Silva Coutinho, Iluska, orient II. Título. 